Prepared in cooperation with the Virginia Department of Environmental Quality

\title{
Hydrogeologic Framework and Hydrologic Conditions of the Piney Point Aquifer in Virginia
}

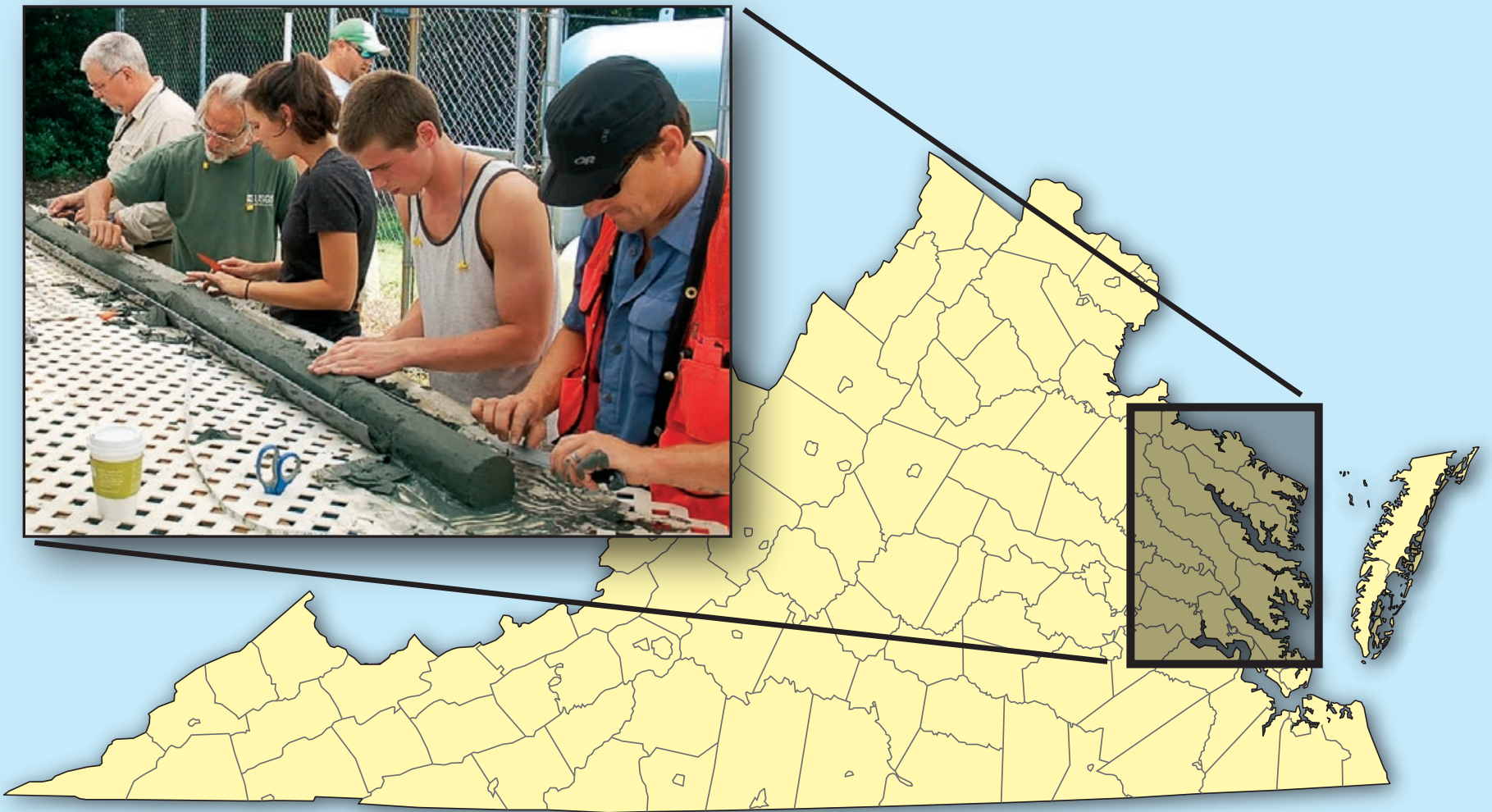

Scientific Investigations Report 2017-5041 
Cover. Geologists of the U.S. Geological Survey (USGS) and Virginia Department of Environmental Quality (VA DEO) processing a sediment core from the Banbury Cross corehole, USGS borehole 57G128, York County, Virginia. The core is from 1 of 366 boreholes that intersect the Piney Point aquifer in Virginia. Extents, compositions, configurations, and geologic relations of six geologic units that compose the Piney Point aquifer were determined from geologists' logs of sediment core and cuttings, borehole geophysical logs, and drillers' logs. Investigation of the Piney Point aquifer was jointly undertaken by USGS and the VA DEQ under the USGS Cooperative Studies Program. Photograph by T. Scott Bruce, Virginia Department of Environmental Quality. 


\section{Hydrogeologic Framework and Hydrologic Conditions of the Piney Point Aquifer in Virginia}

By E. Randolph McFarland

Prepared in cooperation with the Virginia Department of Environmental Quality

Scientific Investigations Report 2017-5041 


\title{
U.S. Department of the Interior \\ RYAN K. ZINKE, Secretary
}

\section{U.S. Geological Survey William H. Werkheiser, Acting Director}

\author{
U.S. Geological Survey, Reston, Virginia: 2017
}

For more information on the USGS - the Federal source for science about the Earth, its natural and living resources, natural hazards, and the environment—visit http://www.usgs.gov or call 1-888-ASK-USGS.

For an overview of USGS information products, including maps, imagery, and publications, visit http://www.usgs.gov/pubprod/.

Any use of trade, firm, or product names is for descriptive purposes only and does not imply endorsement by the U.S. Government.

Although this information product, for the most part, is in the public domain, it also may contain copyrighted materials as noted in the text. Permission to reproduce copyrighted items must be secured from the copyright owner.

Suggested citation:

McFarland, E.R., 2017, Hydrogeologic framework and hydrologic conditions of the Piney Point aquifer in Virginia: U.S. Geological Survey Scientific Investigations Report 2017-5041, 63 p., 2 pl., and CD-ROM, https://doi.org/10.3133/ sir20175041. 


\section{Acknowledgments}

This study was supported by the Virginia Department of Environmental Quality (VA DEQ). Special thanks for program planning go to Scott W. Kudlas and T. Scott Bruce of the VA DEO. C. Richard Berquist of the Virginia Division of Geology and Mineral Resources generously provided geologic logs of boreholes in the southwestern part of the study area, and John T. Haynes of James Madison University generously provided petrographic analyses of limestone of the Piney Point Formation. Thanks also are extended to the many drillers and owners of water-supply wells, who provided well data from across the Virginia Coastal Plain. The scientific integrity of this report was aided greatly by reviews from Mark D. Kozar and Jason P. Pope of the U.S. Geological Survey (USGS). The editorial and graphical quality of the report was aided greatly by Ruth Larkins and Denis Sun of the USGS.

This project has been funded in part by the U.S. Environmental Protection Agency (EPA) under assistance agreement BG - 98392505-1 to the VA DEO. The contents of this document do not necessarily reflect the views and policies of the EPA, nor does the EPA endorse trade names or recommend the use of commercial products mentioned in this document. 


\section{Contents}

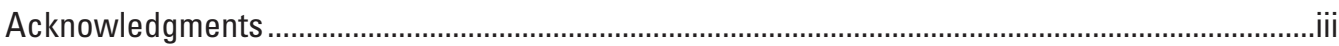

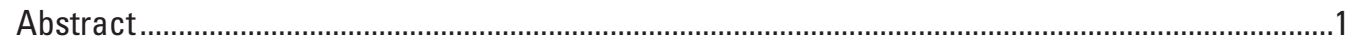

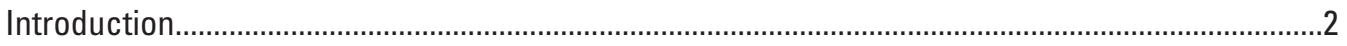

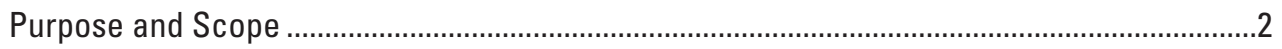

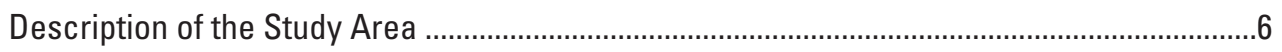

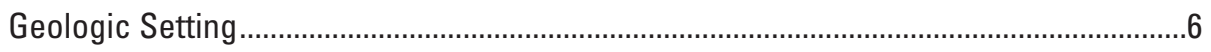

Groundwater Conditions...........................................................................................

Methods of Investigation...................................................................................................

Hydrogeologic Framework of the Piney Point Aquifer in Virginia ................................................

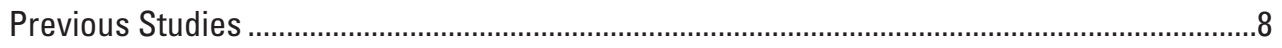

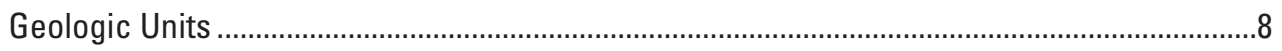

Nanjemoy Formation Potapaco Member.......................................................................

Nanjemoy Formation Woodstock Member..................................................................

Piney Point Formation .............................................................................................

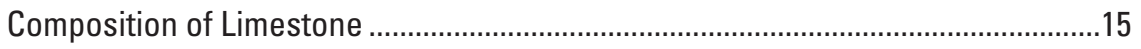

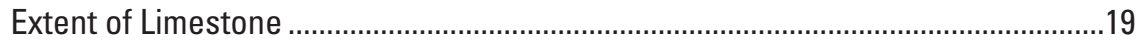

Gosport Formation Equivalent Sediments ................................................................20

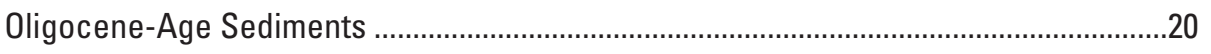

Old Church Formation ............................................................................................23

Calvert Formation, Newport News Unit and Basal Plum Point Member.........................23

Fine-Grained Calvert Formation Plum Point Member ..................................................25

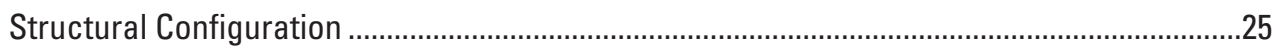

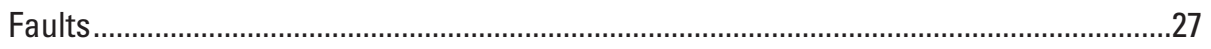

Impact-Crater Resurge Channel ..............................................................................28

Hydrologic Conditions of the Piney Point Aquifer in Virginia ..........................................................29

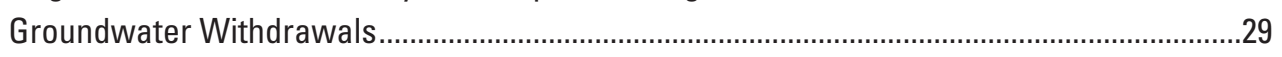

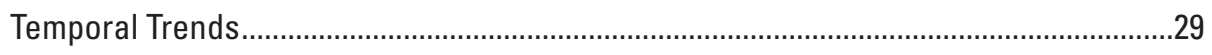

Spatial Distribution of Reported Withdrawals ................................................................

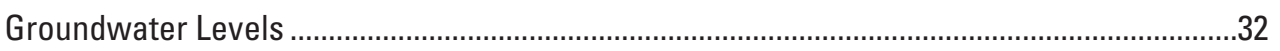

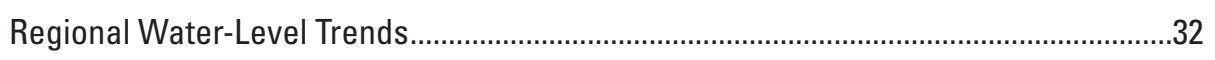

Water-Level Cone of Depression ..............................................................................

Water-Level Interactions on the York-James Peninsula...................................................

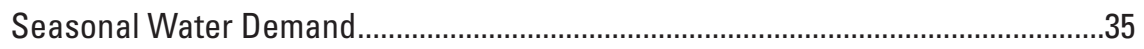

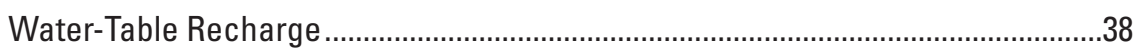

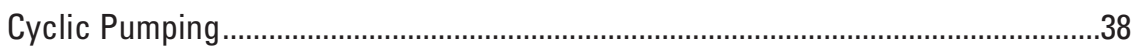

Hydraulic Properties.....................................................................................................

Historical Aquifer Tests.........................................................................................40

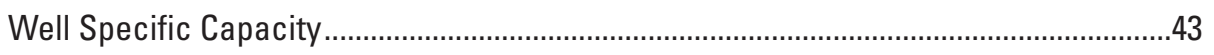

Aquifer-Component Test..........................................................................................

Groundwater Research Station.............................................................................43

Pumping and Water-Level Measurement..................................................................44

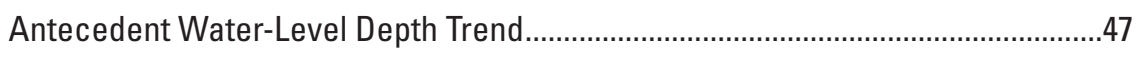

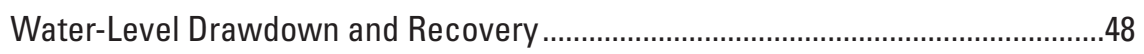


Conceptual Two-Layer Aquifer Model ..................................................................48

Geologic-Unit Transmissivities and Hydraulic Conductivities..................................51

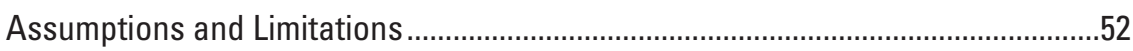

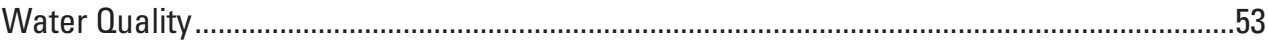

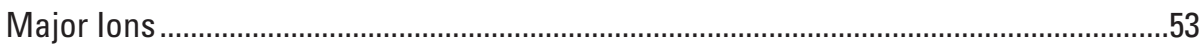

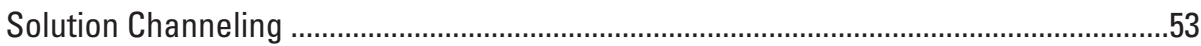

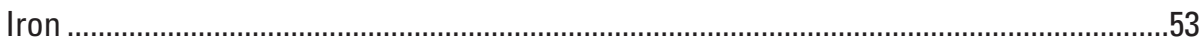

Chloride

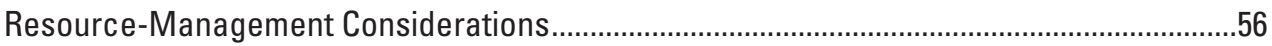

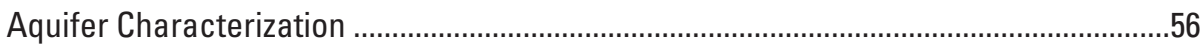

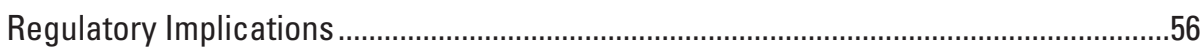

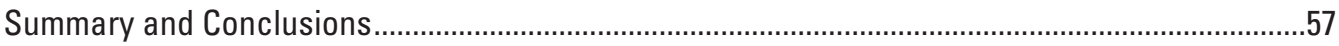

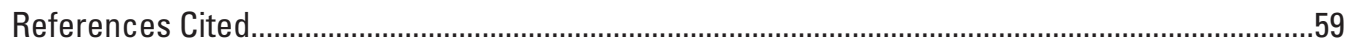

Appendix 1. Borehole Geologic-Unit Top-Surface Altitudes, Piney Point Aquifer, Virginia.........63

Appendix 2 Aquifer-Component Test Data, Piney Point Aquifer, Virginia ......................................63

\section{Plates}

1. Location of Boreholes an Extent of Productive Limestone in the Piney Point Aquifer in Virginia ............................................................................................ in pocket

2. Hydrogeologic Sections $A-A^{\prime}, B-B^{\prime}$, and $C-C^{\prime}$ of the Piney Point Aquifer

in Virginia .......................................................................................................... in pocket

\section{Figures}

1. Map showing locations of boreholes, lines of hydrogeologic section, and extent of the Piney Point aquifer and productive limestone in Virginia..........................................

2. Generalized hydrogeologic section and direction of predevelopment groundwater flow in the Coastal Plain in Virginia ................................................................................

3. Simplified stratigraphic relations among hydrogeologic units of the Virginia Coastal Plain and geologic units that compose the Piney Point aquifer ........................................5

4. Representative sediment lithologies and resistivity log from the Banbury Cross corehole, York County, Virginia.

5. Representative sediment lithologies and resistivity log from the Surprise Hill corehole, Northumberland County, Virginia.

6. Map showing altitude and configuration of the top surface of the Nanjemoy Formation Potapaco Member across the Northern Neck, upper Middle Peninsula, and upper York-James Peninsula in Virginia ...

7. Map showing altitude and configuration of the top surface of the Nanjemoy Formation Woodstock Member across the Northern Neck, upper Middle Peninsula, and upper York-James Peninsula in Virginia 
8. Map showing altitude and configuration of the top surface of the Piney Point Formation across the Northern Neck, upper Middle Peninsula, and upper York-James Peninsula in Virginia.

9. Photographs showing representative examples of limestone of the Piney Point Formation in Virginia. $A$, Contrasting cementation among slabbed samples from Haynesville borehole 57M 7, Richmond County, Virginia. B, Photograph from video log of open-hole "barefoot" borehole $55 \mathrm{H} 30$, New Kent County, Virginia

10. Map showing altitude and configuration of the top surface of sediments equivalent to the Gosport Formation across the Northern Neck, upper Middle Peninsula, and upper York-James Peninsula in Virginia

11. Map showing altitude and configuration of the top surface of Oligocene-age sediments across the Northern Neck, upper Middle Peninsula, and upper York-James Peninsula in Virginia.

12. Map showing altitude and configuration of the top surface of the Old Church Formation across the Northern Neck, upper Middle Peninsula, and upper York-James Peninsula in Virginia.

13. Map showing altitude and configuration of the top surface of the Calvert Formation, Newport News unit and basal Plum Point Member across the Northern Neck, upper Middle Peninsula, and upper York-James Peninsula in Virginia

14. Graphs showing reported and estimated domestic groundwater withdrawals during 1900-2009 from $A$, all aquifers in the Virginia Coastal Plain and $B$, the Piney Point aquifer

15. Maps showing locations and rates of reported groundwater withdrawals from the Piney Point aquifer, in Virginia, during A, 2004 and B, 2009

16. Graphs showing $A$, yearly mean water levels in selected observation wells in the Piney Point aquifer, in Virginia, during 1906-2015 and B, map showing locations of selected observation wells in the Piney Point aquifer.

17. Maps showing estimated water levels in the Piney Point aquifer during $A$, September 2008, B, May 2009, and C, August 2009, and D, production- and observation-well locations.

18. Graphs showing water levels in continuously measured observation wells $A$, $57 \mathrm{G} 129$ and 57G130 in York County, B, 55H 27 in New Kent County, and C, 58F 53 in the City of Newport News, Virginia, during March-September 2015, $D$, total daily rainfall downloaded from Weather Underground weather station KVAWILLI12 on September 23, 2015, and $E$, locations of observation wells, selected production wells, weather station, and faults

19. Graphs showing hydrodynamic intractions in northern York County, Viginia, during March 6-8, 2015: $A$, water levels in observation wells 57G129 and 57G130, $B$, vertical hydraulic gradient between observation wells $57 \mathrm{G} 129$ and $57 \mathrm{G} 130, C$, groundwater-withdrawal rates for production well $57 \mathrm{G} 55$, and $D$, groundwaterwithdrawal rates for production well 57G134

20. Maps showing $A$, locations of historical aquifer tests and estimates of transmissivity of the Piney Point aquifer in Virginia and Maryland, and $B$, locations and specific capacities of wells in the Piney Point aquifer.

21. Diagram showing litho-stratigraphy and well construction at the groundwater research station in York County, Virginia. 
22. Graphs showing $A$, data collected prior to and during an aquifer test at the groundwater research center in York County, Virginia, for observation-well water levels and antecedent water-level trends, $B$, barometric pressure downloaded on September 23, 2015, from Weather Underground weather stations KVAWILL119, KVAWILL120, and KVAOILL121, and $C$, tidal stage of James River at the U.S. Geological Survey gaging station 02042222 in Charles City County, Virginia, during March 15-19, 2015.

23. Graphs showing aquifer test water-level $A$, drawdowns and $B$, recoveries in observation well $57 \mathrm{G} 129$ at the groundwater research station in York County, Virginia, March 17-19, 2015

24. Conceptual model of the flow response of a two-layer confined aquifer to an aquifer test during $A$, the early part of the test, and $B$, the late part of the test

25. Map showing distribution of iron and chloride in water in the Piney Point aquifer, Virginia

\section{Tables}

1. Groundwater-withdrawal rates from all aquifers in the Atlantic Coastal Plain in Virginia during 2002 and 2009, and from the Piney Point aquifer during 2004 and 2009.

2. Estimates of transmissivity and storativity of the Piney Point aquifer in Virginia and an adjacent part of Maryland, using aquifer tests, 1972-2011.

3. Summary of well specific capacities in the Piney Point aquifer in Virginia and an adjacent part of Maryland.

4. Estimates of the transmissivities and hydraulic conductivities of geologic units composing the Piney Point aquifer, using aquifer testing at the groundwater research station in York County, Virginia, March 2015. 


\section{Conversion Factors}

U.S. customary units to International System of Units

\begin{tabular}{|c|c|c|}
\hline Multiply & By & To obtain \\
\hline \multicolumn{3}{|c|}{ Length } \\
\hline inch (in.) & 2.54 & centimeter $(\mathrm{cm})$ \\
\hline inch (in.) & 25.4 & millimeter $(\mathrm{mm})$ \\
\hline foot (ft) & 0.3048 & meter $(\mathrm{m})$ \\
\hline mile (mi) & 1.609 & kilometer (km) \\
\hline \multicolumn{3}{|c|}{ Area } \\
\hline square mile $\left(\mathrm{mi}^{2}\right)$ & 259.0 & hectare (ha) \\
\hline square mile $\left(\mathrm{mi}^{2}\right)$ & 2.590 & square kilometer $\left(\mathrm{km}^{2}\right)$ \\
\hline \multicolumn{3}{|c|}{ Flow rate } \\
\hline inch per year (in/yr) & 2.54 & centimeter per year $(\mathrm{cm} / \mathrm{yr})$ \\
\hline foot per year (ft/yr) & 0.3048 & meter per year (m/yr) \\
\hline gallon per minute (gal/min) & 0.06309 & liter per second $(\mathrm{L} / \mathrm{s})$ \\
\hline million gallons per day (Mgal/d) & 0.04381 & cubic meter per second $\left(\mathrm{m}^{3} / \mathrm{s}\right)$ \\
\hline \multicolumn{3}{|c|}{ Aquifer hydraulic properties } \\
\hline foot per minute ( $\mathrm{ft} / \mathrm{min})$ & 0.3048 & meter per minute (m/min) \\
\hline foot squared per day $\left(\mathrm{ft}^{2} / \mathrm{d}\right)$ & 0.09290 & meter squared per day $\left(\mathrm{m}^{2} / \mathrm{d}\right)$ \\
\hline gallon per minute per foot (gal/min/ft) & 0.20699 & liter per second per meter $(\mathrm{L} / \mathrm{s} / \mathrm{m})$ \\
\hline
\end{tabular}

\section{Datum}

Vertical coordinate information is referenced to the National Geodetic Vertical Datum of 1929 (NGVD 29).

Horizontal coordinate information is referenced to the North American Datum of 1927 (NAD 27). Altitude, as used in this report, refers to distance above the vertical datum.

\section{Supplemental Information}

Concentrations of chemical constituents in water are given in milligrams per liter (mg/L). 


\title{
Hydrogeologic Framework and Hydrologic Conditions of the Piney Point Aquifer in Virginia
}

\author{
By E. Randolph McFarland
}

\section{Abstract}

The Piney Point aquifer in Virginia is newly described and delineated as being composed of six geologic units, in a study conducted by the U.S. Geological Survey in cooperation with the Virginia Department of Environmental Quality (VA DEQ). The eastward-dipping geologic units include, in stratigraphically ascending order, the

- sand of the Nanjemoy Formation Woodstock Member,

- interbedded limestone and sand of the Piney Point Formation,

- silty and clayey sand of the Gosport Formation equivalent sediments,

- silty sand of the Oligocene-age sediments,

- silty fine-grained sand of the Old Church Formation, and

- silty sand of the Calvert Formation, Newport News unit and basal Plum Point Member.

Identification of geologic units is based on typical sediment lithologies of geologic formations. Fine-grained sediments that compose confining units positioned immediately above and below the Piney Point aquifer are also described.

The Piney Point aquifer is one of several confined aquifers within the Virginia Coastal Plain and includes a highly porous and solution-channeled indurated limestone within the Piney Point Formation from which withdrawals are made. The limestone is relatively continuous laterally across central parts of the Northern Neck, Middle Peninsula, and YorkJames Peninsula. Other geologic units are of variable extent. The configurations of most of the geologic units are further affected by newly identified faults that are aligned radially from the Chesapeake Bay impact crater and create constrictions or barriers to groundwater flow. Some geologic units are also truncated beneath the lower Rappahannock River by a resurge channel associated with the impact crater.

Groundwater withdrawals from the Piney Point aquifer increased from approximately 1 million gallons per day (Mgal/d) during 1900 to $7.35 \mathrm{Mgal} / \mathrm{d}$ during 2004. As a result, a water-level cone of depression in James City and northern York Counties was estimated to be as low as 70 feet (ft) below the National Geodetic Vertical Datum of 1929 (NGVD 29) by
2005. Withdrawals decreased to $5.01 \mathrm{Mgal} / \mathrm{d}$ by 2009 as withdrawals were shifted toward other sources, and by 2015 water levels had recovered to approximately $50 \mathrm{ft}$ below NGVD 29 .

The mean estimated transmissivity of the Piney Point aquifer in York and James City Counties is 16,300 feet squared per day $\left(\mathrm{ft}^{2} / \mathrm{d}\right)$, but farther north it is only $925 \mathrm{ft}^{2} / \mathrm{d}$. The mean well specific capacity in York and James City Counties is 11.4 gallons per minute per foot $(\mathrm{gal} / \mathrm{min} / \mathrm{ft})$. Farther north in Virginia, mean specific capacity is only $2.26 \mathrm{gal} / \mathrm{min} / \mathrm{ft}$, and in Maryland it is $0.99 \mathrm{gal} / \mathrm{min} / \mathrm{ft}$. The northward decrease in specific capacity probably reflects the northward decrease in transmissivity, which results from poor development of the solution-channeled limestone.

An aquifer test in northern York County induced vertical leakage to the solution-channeled limestone from overlying silty sand and a change in response of the aquifer to pumping from a single layer to two layers. Transmissivity of the limestone of approximately $19,800 \mathrm{ft}^{2} / \mathrm{d}$ was distinguished from the silty sand of approximately $2,500 \mathrm{ft}^{2} / \mathrm{d}$.

Most of the water in the Piney Point aquifer is slightly alkaline with moderate concentrations primarily of sodium and bicarbonate that are slightly undersaturated with respect to calcite. Iron concentrations are generally less than 0.3 milligrams per liter $(\mathrm{mg} / \mathrm{L})$. Mixing of freshwater with seawater has elevated chloride concentrations to the southeast to as much as $7,120 \mathrm{mg} / \mathrm{L}$.

Information on the Piney Point aquifer can benefit waterresource management in siting production wells, predicting likely well yield, and anticipating water-level response to withdrawals. Models that vertically discretize individual geologic units can potentially be used to evaluate groundwater flow in greater detail by representing lateral flow and vertical leakage among the geologic units.

Because groundwater withdrawals are made primarily from the limestone and sand of the Piney Point Formation, the VA DEQ has considered regarding the limestone and sand singly as a regulated aquifer apart from the other geologic units. Under current policy in Virginia, if only the limestone and sand were regarded as a regulated aquifer, a greater amount of drawdown would be allowed than is allowed for the Piney Point aquifer consisting of six geologic units. Some production wells intercept multiple geologic units, and the units can undergo water-level decline and vertical leakage induced by pumping from the limestone and sand. Whether the other geologic units are to be regarded as regulated aquifers is an additional consideration for the VA DEQ. 


\section{Introduction}

The Atlantic Coastal Plain Physiographic Province (Coastal Plain) stretches from Cape Cod, Massachusetts southward to the Gulf of Mexico and offshore to the Continental Shelf. In the eastern part of Virginia, the Coastal Plain occupies an area of approximately 13,000 square miles ( $\mathrm{mi}^{2}$, fig. 1). Groundwater in the Virginia Coastal Plain is a heavily used resource. The rate of groundwater withdrawal is estimated to have been close to zero during the late 1800 s but increased continuously during the 20th century. Since 2000, withdrawal rates for Coastal Plain aquifers in Virginia have been maintained at approximately 130 million gallons per day (Mgal/d) (Masterson and others, 2016). As a result, groundwater levels have declined by as much as 200 feet (ft) near major withdrawal centers, and flow gradients have been altered from a previously seaward direction to a landward direction, creating the potential for saltwater intrusion. Continued withdrawal is expected to further water-level declines and intrusion potential, and thereby limit continued use of the resource.

In order to manage the groundwater resource, the Virginia Department of Environmental Quality (VA DEQ) regulates groundwater withdrawals. Withdrawals within the Virginia Coastal Plain of 300,000 gallons or more during any month must be approved under the VA DEQ Groundwater Withdrawal Permitting Program. Groundwater users are required to submit withdrawal-related information needed to evaluate the potential effects of the withdrawals on the aquifer system. In order to provide a valid context within which to make resource-management decisions, the VA DEQ has also maintained a sound scientific understanding of Virginia Coastal Plain geology and hydrology through a cooperative program of hydrogeologic investigation with the U.S. Geological Survey (USGS). Advancements made by recent studies include discovery of the Chesapeake Bay impact crater (Powars and Bruce, 1999), revision of the hydrogeologic framework (McFarland and Bruce, 2006), digital model simulation of groundwater flow (Heywood and Pope, 2009), characterization of groundwater chemical quality (McFarland, 2010), detailed analysis of the Potomac aquifer (McFarland, 2013), and development of a strategy to monitor the movement of saltwater (McFarland, 2015).

In addition to the management efforts, improved information on the Piney Point aquifer is needed to effectively plan for a sustainable water supply. The Piney Point aquifer supplies urban and suburban areas from large municipal wells that produce as much as 400 gallons per minute (gal/min). Widespread rural areas are supplied by smaller commercial and domestic wells that produce $10-50 \mathrm{gal} / \mathrm{min}$. The productive part of the aquifer, however, is limited to a solution-channeled limestone in which most water-supply wells are completed. Moreover, large withdrawals from the productive limestone are geographically concentrated within a relatively small area centered on James City County. A resulting water-level cone of depression has been estimated at times to be deeper than $80 \mathrm{ft}$ below sea level (Heywood and Pope, 2009). Water demands from the Piney Point aquifer are expected to expand as a result of ongoing development along the Interstate 64 corridor (plate 1).

The Piney Point aquifer is one of several confined aquifers of intermediate thickness and depth within the Virginia Coastal Plain (fig. 2). The Piney Point aquifer occupies much of the Coastal Plain in Virginia and adjacent parts of Maryland and North Carolina (fig. 1). The aquifer is a composite, however, of several geologic units that have different lateral extents (fig. 3). Although the geologic units are stratigraphically and lithologically distinct, they have not been individually described and delineated in a hydrologic context. Of greatest importance, the extent, continuity, and other hydrologic aspects of the productive limestone are poorly known. Moreover, withdrawals, water levels, hydraulic properties, and flow interaction of the Piney Point aquifer have not been comprehensively documented.

To address the information needs, a study of the Piney Point aquifer was undertaken by the USGS in cooperation with the VA DEQ. Aquifer sediments were described, and other hydrologic aspects were characterized, by different study components completed during 2009, 2013, and 2015.

\section{Purpose and Scope}

The Piney Point aquifer is characterized to address information needs for water-resource management in the Virginia Coastal Plain. The focus is geographically constrained to the area surrounding the productive limestone (fig. 1), designated here as the study area, in which withdrawals from the Piney Point aquifer are made. Although the Piney Point aquifer subcrops along major river valleys that cross its westernmost margin, within the designated study area, the aquifer is entirely confined.

A hydrogeologic framework of the Piney Point aquifer is presented. Extents, compositions, configurations, and geologic relations of six geologic units that compose the Piney Point aquifer are described and are illustrated by photographs of sediment lithologies, structural-contour maps, and hydrogeologic sections. Structural features of the Piney Point aquifer are also described.

Hydrologic conditions of the Piney Point aquifer are described. Groundwater withdrawals in the Virginia Coastal Plain during 1900-2009 are summarized to distinguish among large regulated withdrawals and small unregulated withdrawals from the Piney Point aquifer and other aquifers. Spatial and temporal water-level trends in the Piney Point aquifer are summarized regionally for 1906-2015, within the cone of depression centered on James City County for 2008-09, and on the York-James Peninsula for March-September 2015. Aquifertest estimates of transmissivity and storativity of the Piney Point aquifer are presented and are summarized and compared to well specific capacities to determine spatial trends. Results of an aquifer test conducted by the VA DEQ in York County also are presented and analyzed to determine transmissivi- 


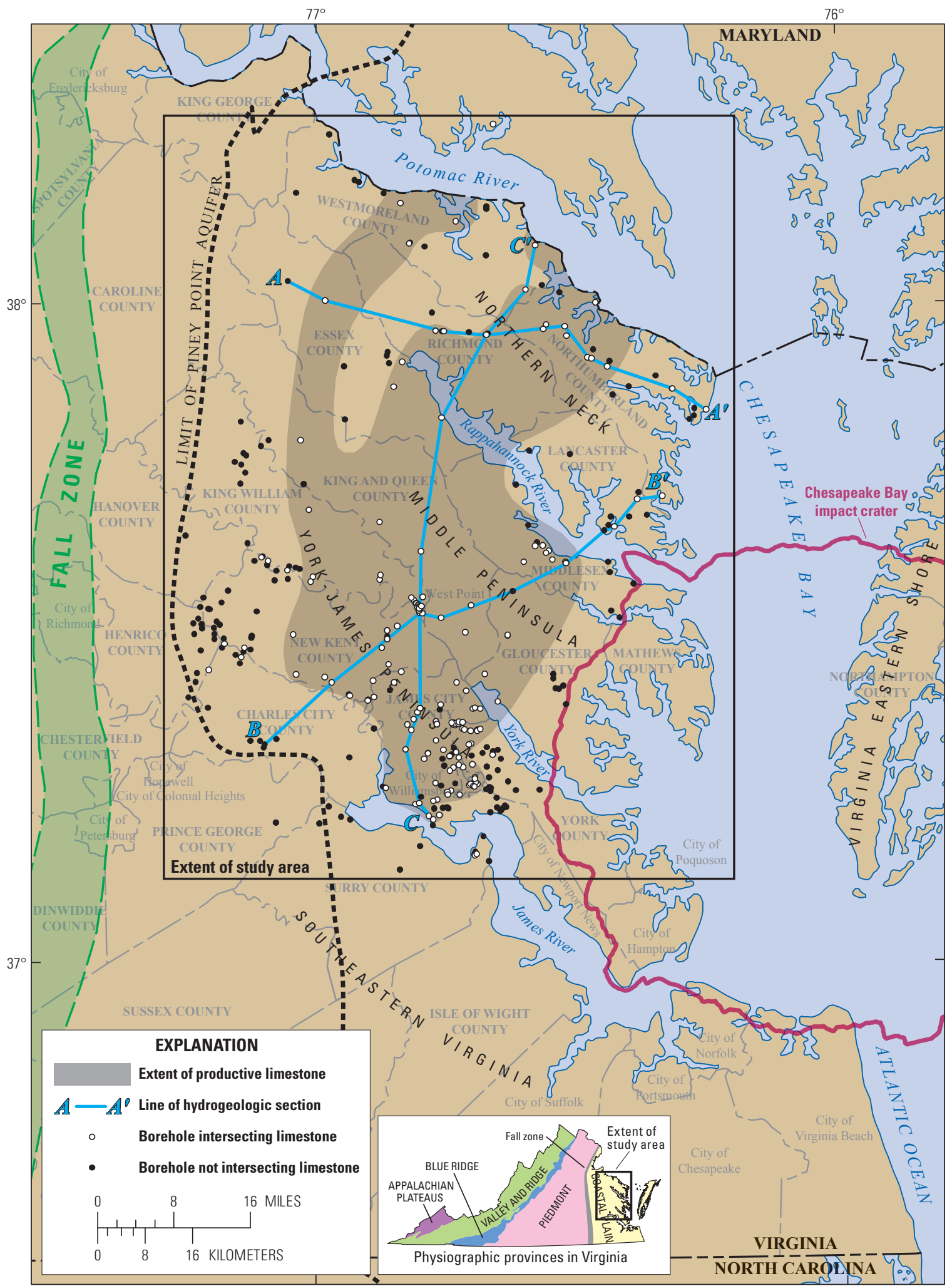

Base from U.S. Geological Survey, 1973 State of Virginia, 1:500,000

Figure 1. Locations of boreholes, lines of hydrogeologic section, and extent of the Piney Point aquifer and productive limestone in Virginia. (Hydrogeologic sections are shown on plate 2.) 


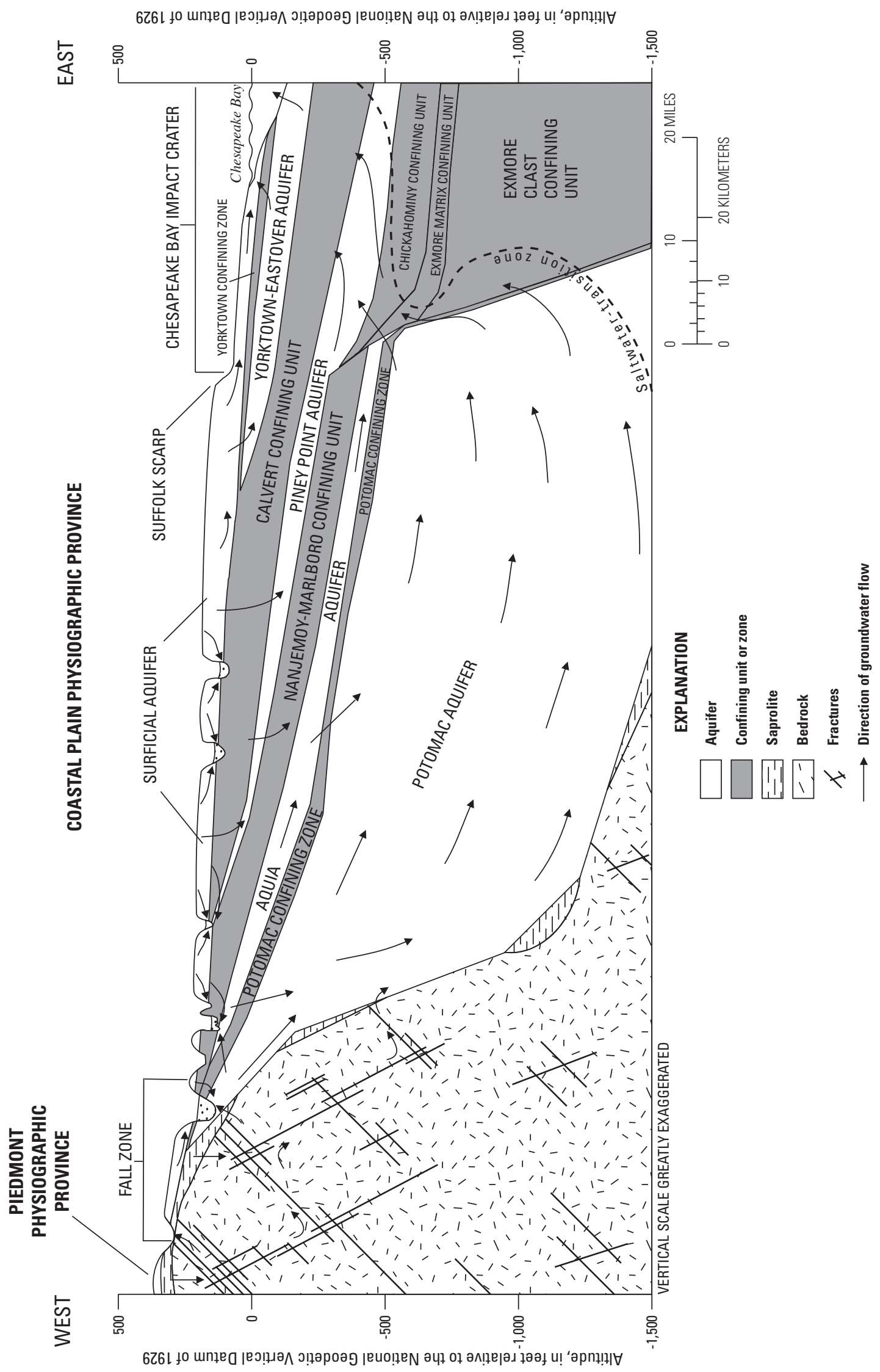

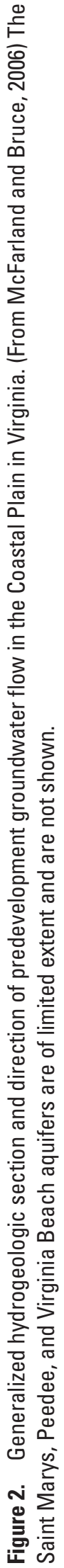




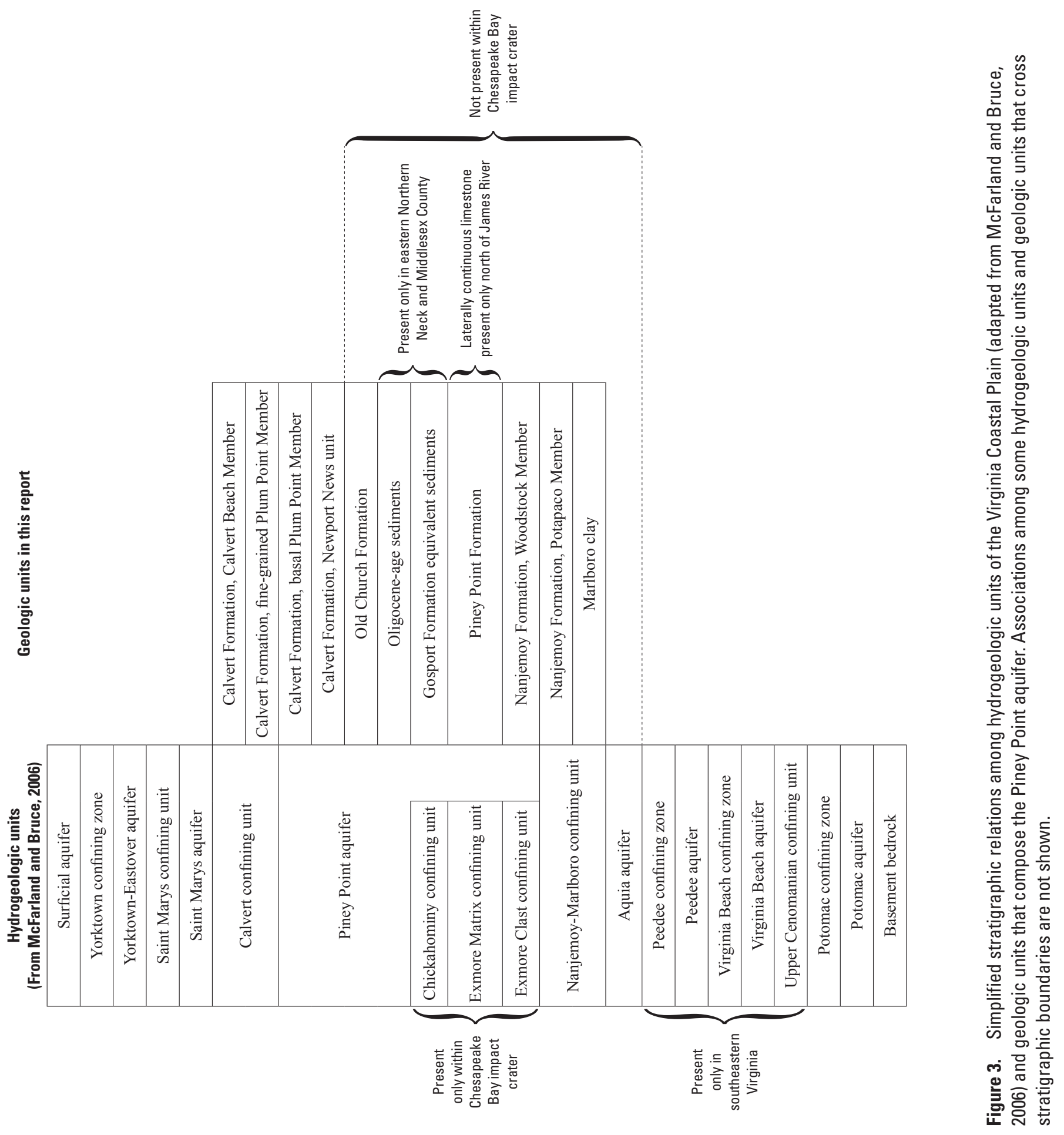


ties and hydraulic conductivities among, and flow interaction between, geologic units that compose the Piney Point aquifer.

The relevance of the above information to water-resource management is discussed. Applications of data and concepts to aid characterization of the aquifer are described. Additionally, implications for regulation of the Piney Point aquifer are examined.

\section{Description of the Study Area}

Eastern Virginia is encompassed by the Atlantic Coastal Plain Physiographic Province (Coastal Plain) (fig. 1). Primary urban centers include the cities of Fredericksburg and Richmond along the western margin, and several cities and counties to the east and south. The remainder of the Virginia Coastal Plain is mostly rural and fairly evenly divided between cropland and forest. Land-surface altitudes range from more than $300 \mathrm{ft}$ above sea level across some western uplands to sea level along the Atlantic coast. Rolling terrain and deeply incised stream valleys are present to the northwest, and gently rolling-to-level terrain, broad stream valleys, and extensive wetlands are present to the east and south. Primary rivers include the Potomac, Rappahannock, York, and James Rivers (fig. 1), which receive flow from dense and extensive networks of tributaries that extend across their entire drainage basins. These rivers collectively drain to the east and southeast into the Chesapeake Bay and become estuarine upon entering the Virginia Coastal Plain. Distinct landmasses defined by the estuarine rivers include, from north to south, the Northern Neck, Middle Peninsula, York-James Peninsula, and Southeastern Virginia (fig. 1). Chesapeake Bay separates these parts of the Virginia Coastal Plain to the west from the Virginia Eastern Shore to the east.

\section{Geologic Setting}

The Coastal Plain is underlain by a seaward-thickening wedge of regionally extensive, generally eastward-dipping strata of unconsolidated to partly consolidated sediments of Cretaceous, Paleogene, Neogene, and Quaternary age that unconformably overlie a basement of consolidated bedrock (fig. 2). The sediment wedge extends from Cape Cod, Massachusetts, southward to the Gulf of Mexico and offshore to the Continental Shelf. Sediment thickness in Virginia ranges from $0 \mathrm{ft}$ at its western margin to more than $6,000 \mathrm{ft}$ along the Atlantic coast. The sediments were deposited by seaward progradation of fluvial plains and deltas along the North American continental margin, followed by a series of transgressions and regressions by the Atlantic Ocean in response to changes in sea level. Fluvial strata primarily of Cretaceous age are overlain by marine strata of Paleogene and Neogene age, which are overlain in turn by terrace and flood-plain deposits primarily of Quaternary age.

Coastal Plain sediments in Virginia near the mouth of the present-day Chesapeake Bay were affected during the
Eocene Epoch by the impact of an asteroid or comet (Powars and Bruce, 1999). The buried Chesapeake Bay impact crater is greater than 50 miles (mi) in diameter and extends across a large part of the southeastern Virginia Coastal Plain (fig. 1). The crater formed within the preexisting sediments and contains unique impact-related materials as deep as basement bedrock. Subsequent deposition has buried crater-fill sediments approximately 1,000 ft below the present-day land surface.

The Piedmont Physiographic Province (Piedmont) lies to the west of the Coastal Plain (figs. 1 and 2) and is underlain by igneous and metamorphic bedrock of late Proterozoic and early Paleozoic age, along with fault-bounded structural basins containing sedimentary and igneous bedrock of Triassic and Jurassic age. The transitional part of the Coastal Plain adjacent to the Piedmont is designated as the Fall Zone, a belt several miles wide through which streams have eroded Coastal Plain sediments to expose Piedmont bedrock in the valley floors (Mixon and others, 1989). From the Fall Zone, the Piedmont bedrock slopes eastward beneath the sediment wedge to constitute the basement that underlies the Coastal Plain.

\section{Groundwater Conditions}

Virginia Coastal Plain sediments form a series of hydrogeologic units (fig. 3) (McFarland and Bruce, 2006). Permeable sediments, through which most groundwater flows, are designated as aquifers, and less permeable sediments that restrict flow are designated as confining units or zones. None of the hydrogeologic units span the entire Virginia Coastal Plain. A complex history of sediment deposition has produced numerous lateral variations in sediment composition. Consequently, the positions of hydrogeologic-unit margins are divergent, and their aerial distribution has a complex overlapping configuration. In particular, major discontinuities are present along the margin of the Chesapeake Bay impact crater (fig. 2).

Groundwater in the Virginia Coastal Plain is present in pores between the sediment grains. Precipitation that infiltrates the land surface and percolates to the water table either flows relatively short distances and discharges to nearby streams or leaks downward to recharge deeper confined aquifers (fig. 2). Flow through the confined aquifers is primarily lateral in the down-dip direction to the east and toward major withdrawal centers and discharge areas along large rivers and the Atlantic coast. Dense saline water at the transition zone between freshwater and saltwater causes the confined groundwater to discharge by upward leakage across intervening confining units and zones. In addition, stagnant saltwater within sediments filling the Chesapeake Bay impact crater has been theorized to cause a lateral divergence of flow to either side of the crater (McFarland, 2010).

Groundwater withdrawal in the Virginia Coastal Plain increased continuously during the past century and totaled approximately $130 \mathrm{Mgal} / \mathrm{d}$ for the past decade (Masterson and others, 2016). An estimated 200,000 small and unregulated withdrawals widely span the Virginia Coastal Plain to supply primarily individual domestic use (Pope and others, 2008) and 
probably result in localized water-level declines. Most large withdrawals are regulated by the VA DEQ. Regional waterlevel cones of depression as deep as $150 \mathrm{ft}$ below sea level are centered on the largest individual withdrawals that supply industrial facilities at the cities of Franklin and West Point (fig. 1), where all but the deepest part of the aquifer system contains freshwater. As a result, the hydraulic gradient across the Virginia Coastal Plain has been regionally redirected landward and approximately doubled from pre-pumping conditions. Farther east and closer to saltwater, many additional large withdrawals supply public drinking water and diverse other uses and have an additive effect that contributes to the landward hydraulic gradient. Current (2017) region-wide rates of water-level decline vary between approximately 1 and 2 feet per year. In addition, removal of withdrawn water from aquifer storage has resulted in sediment compaction and widespread land subsidence (Eggleston and Pope, 2013).

\section{Methods of Investigation}

Extents, compositions, configurations, and geologic relations of the six geologic units that compose the Piney Point aquifer in Virginia were determined. Data were compiled from records on file at the USGS Virginia Water Science Center that contain drillers', geologists', and geophysical logs of 366 boreholes within and in proximity to the productive limestone part of the Piney Point aquifer. Geophysical logs of 165 boreholes were interpreted to distinguish geologic relations and determine extents and altitudes among geologic units that compose the Piney Point aquifer. Stratigraphic correlation of the geologic units among boreholes was supported by construction of three hydrogeologic sections. The sections were oriented to intercept 29 boreholes with the highest quality data, including descriptions of sediment core or drill cuttings. The geologic units were further delineated by construction of seven structural-contour maps that represent the altitudes and configurations of their top surfaces, along with that of the Nanjemoy Formation Potapaco Member, which forms the base of the Piney Point aquifer. Alignments of faults that intercept the geologic units and a resurge channel associated with the Chesapeake Bay impact crater that truncate some geologic units were interpreted from stratigraphic correlation and structure-contour mapping.

Petrographic analyses of the productive limestone part of the Piney Point aquifer were provided by John T. Haynes of James Madison University, Department of Geology and Environmental Science. Sediment descriptions from drillers' logs and from geologists' logs of drill cuttings and sediment cores were examined to determine the presence or absence of the productive limestone within each borehole and to estimate the lateral extent of the productive limestone.

Annual rates of groundwater withdrawals in the Virginia Coastal Plain during 1900-2009 were obtained from a groundwater model of the North Atlantic Coastal Plain recently developed by USGS (Masterson and others, 2016). Data were summarized to distinguish between withdrawals from the Piney Point aquifer and those from other aquifers. Large industrial, municipal, and commercial withdrawals that are regulated by the VA DEQ were distinguished from estimates of unregulated domestic withdrawals.

Water-level measurements for the Piney Point aquifer were obtained from two sources. Firstly, the USGS National Water Information System (NWIS) provided region-wide long-term discrete water levels measured during 1906-2015 in 19 wells and continuously measured water levels during March-September 2015 in 4 wells located on the York-James Peninsula. Second, continuously measured water levels during 2008-09 in 10 production wells within the cone of depression (Heywood and Pope, 2009) centered on James City County were obtained from the James City Service Authority (JCSA). Seasonal high and low static water levels were estimated from these data by graphical analysis. Water-level measurements from both sources were summarized to determine spatial and temporal trends. For comparison to water levels on the YorkJames Peninsula, continuously measured rates of withdrawal from two production wells during March 6-8, 2015, were obtained from the City of Newport News Waterworks. Daily rainfall during March 1, 2015-September 23, 2015, was downloaded on September 23, 2015, from the Weather Underground Web site for weather station KVAWILLI12.

Hydraulic properties of the Piney Point aquifer were estimated from 14 aquifer tests conducted during 1972-2011 in Virginia and an adjacent part of Maryland. Estimates of aquifer transmissivity and storativity were compiled from time series water-level measurements and allied aquifer-test data on file at the USGS Virginia Water Science Center, and from other published sources. Transmissivity values were summarized to determine spatial trends. For comparison, specific capacities were compiled from the USGS NWIS records for 53 wells completed in the Piney Point aquifer in Virginia and from a published source (Drummond, 1984) of 123 wells in Maryland.

Transmissivities and hydraulic conductivities among, and flow interaction between, geologic units that compose the Piney Point aquifer were determined by using an aquifer test conducted by the VA DEQ in York County during March 17-19, 2015. Water levels were measured at 1-second intervals during test antecedent, drawdown, and recovery periods. Drawdown and recovery data were adjusted for antecedent water-level trends using (1) continuously measured tide stages compiled from the USGS NWIS of the estuarine James River at USGS gaging station 02042222 in Charles City County and (2) continuously measured barometric pressure downloaded on September 23, 2015, from the Weather Underground Web sites for weather stations KVAWILLI19, KVAWILLI20, and KVAWILLI21. Early test response of the productive limestone was distinguished from late test response of the combined geologic units on the basis of a two-layer aquifer conceptual model and using the graphical aquifer-test analysis method of Cooper and Jacob (1946). 


\section{Hydrogeologic Framework of the Piney Point Aquifer in Virginia}

The Piney Point aquifer spans much of the Coastal Plain in Virginia and adjacent parts of Maryland and North Carolina (fig. 1). Although the Piney Point aquifer subcrops along major river valleys that cross its westernmost margin, the aquifer is entirely confined within the designated study area that surrounds the productive limestone from which withdrawals from the aquifer are made (see section "Introduction"). The study area spans the Northern Neck, Middle Peninsula, and York-James Peninsula in Virginia and part of Maryland near the Potomac River (fig. 1; plate 1).

The Piney Point aquifer is one of several aquifers of intermediate thickness and depth (fig. 2). It generally consists of marine, medium- to coarse-grained, variably fossiliferous and calcified quartz, glauconite, and phosphate sand. These sediments were deposited across the Atlantic Continental Shelf between approximately 11 and 49 million years ago during parts of the Eocene, Oligocene, and Miocene Epochs (McFarland and Bruce, 2006).

The Piney Point aquifer is positioned above silty and clayey fine- to medium-grained glauconite and quartz sand and clay of the Nanjemoy-Marlboro confining unit across most of its extent except within the Chesapeake Bay impact crater, where it is above the clay of the Chickahominy confining unit (fig. 2). It is positioned below the silty fine-grained quartz sand of the Calvert confining unit across most of its extent, except to the southwest where it is below the clay and clayey finegrained quartz sand of the Saint Marys confining unit.

\section{Previous Studies}

For more than a century, the Piney Point aquifer has been designated with increasing specificity. Early hydrologic studies of the Virginia Coastal Plain generally described an aquifer consisting of sediments of the Pamunkey and (or) Chesapeake Groups or their equivalents, of which individual geologic formations that compose the Piney Point aquifer are only parts (Darton, 1896; Sanford, 1913; Cederstrom, 1939, 1945, 1946, 1968; Geraghty and Miller, Consulting Ground-Water Geologists, 1967; Virginia State Water Control Board, 1973; Siudyla and others, 1977, 1981; Ellison and Masiello, 1979; Newton and Siudyla, 1979; Wigglesworth and others, 1984). Subsequently, several closely timed studies designated the Chickahominy-Piney Point aquifer to include sediments of the Piney Point Formation and associated formations (Hamilton and Larson, 1988; Laczniak and Meng, 1988; Meng and Harsh, 1988; Harsh and Laczniak, 1990). Similar designation was made for equivalent sediments in adjacent states during approximately the same period, including the Piney Point aquifer in Maryland (Vroblesky and Fleck, 1991) and the Castle Hayne aquifer in North Carolina (Winner and Coble, 1996).

Designation by previous studies of the ChickahominyPiney Point aquifer in Virginia was based on sediments that are lithologically similar to those of the Piney Point Formation, are thought to be of late Eocene age, and were geologically designated at the time as the Chickahominy Formation. Following the discovery of the Chesapeake Bay impact crater, sediments of late Eocene age in the Virginia Coastal Plain were reclassified (Powars and Bruce, 1999; Powars, 2000). The Chickahominy Formation currently (2017) is geologically recognized as a clay associated with the impact crater and has been hydrologically designated as the Chickahominy confining unit (fig. 3 left side) (McFarland and Bruce, 2006). Hence, inclusion of the Chickahominy Formation as part of the Piney Point aquifer has been superseded.

Some previous studies included sediments as part of the Chickahominy-Piney Point aquifer generally south of the James River that are now recognized as composing several geologic formations ranging in age from Late Cretaceous through late Miocene (Powars, 2000). Accordingly, these sediments have been re-designated as composing several other hydrogeologic units and are no longer considered part of the Piney Point aquifer (McFarland and Bruce, 2006).

Because of their vertical proximity, sediments of several individual geologic formations were considered by previous studies to be closely connected hydraulically and thereby were designated as a single Piney Point aquifer (Hamilton and Larson, 1988; Laczniak and Meng, 1988; Meng and Harsh, 1988; Harsh and Laczniak, 1990; McFarland and Bruce, 2006; McFarland, 2010). The sediments were assumed to function as a continuous medium through which water moves essentially uninterrupted at local and regional scales. Groundwater withdrawal, however, is primarily from a productive solutionchanneled limestone and interbedded sand that compose the Piney Point Formation.

\section{Geologic Units}

Lithologies and other aspects are individually described for the six geologic units that compose the Piney Point aquifer. Descriptions are geographically constrained to the designated study area surrounding the productive limestone from which withdrawals from the Piney Point aquifer are made. Finegrained sediments of confining units that immediately overlie and underlie the aquifer are also described.

The geologic units are presented in stratigraphically ascending order. Descriptions include sediment geologic relations; texture; mineralogic composition; color based on the Munsell soil color classification system (Munsell Color, 1998); borehole resistivity-log signature; and geologic-unit extents, top-surface altitudes, and configurations.

The geologic units are based on interpretation undertaken during 2013 of drillers', geologists', and geophysical logs of 366 boreholes located within the study area (fig. 1; plate 1); logs are on file at the USGS Virginia and West Virginia Water Science Center. Geologic relations among, and altitudes of, the geologic units were determined from geophysical logs of 165 of the boreholes and digitally tabulated (Appendix 1; McFarland, 2017). Hydrogeologic sections illustrate the stratigraphic 
correlation of the geologic units among 29 borehole resistivity logs (plate 2).

Altitudes were not tabulated for all geologic units at every borehole (Appendix 1; McFarland, 2017). Many boreholes lack geophysical logs and were generally used only to determine the presence of limestone of the Piney Point Formation on the basis of drillers' logs (see section "Piney Point Formation"). Typically in these instances, only the top-surface altitude of the Piney Point Formation is tabulated if the limestone is present. Additionally, among boreholes having geophysical logs, not all are deep enough to intercept all geologic units. The quality of parts of some geophysical logs precludes the interpretation of some geologic-unit altitudes. Two of the geologic units are present only at a relatively small number of boreholes in the northeastern part of the study area.

A series of structural-contour maps delineate top-surface altitudes and configurations of the geologic units, along with the underlying fine-grained sediments that form the base of the Piney Point aquifer. Top surfaces are contoured only to the extent of boreholes used in this study. Most geologic units span westward beyond the boreholes and are approximated by the generalized western limit of the Piney Point aquifer (McFarland and Bruce, 2006). Two of the geologic units are constrained to the far northeast and are represented by separate western limits. At eastward locations, most of the geologic units were either excavated by, or have not been preserved within, the Chesapeake Bay impact crater. Borehole data along the impact crater, however, are not adequate to delineate these margins, which are likely highly complex.

The geologic units are designated here in a hydrologic context and are based primarily on litho-stratigraphic correlation. By contrast, formally recognized geologic formations represent specific intervals of time. Although geologic formations can exhibit a single typical lithology, sediment composition within a formation commonly varies as a result of changing depositional environments or in proximity to formation contacts where burrowing or other forms of sediment reworking have occurred. Interpretation of borehole geophysical logs cannot solely provide a reliable basis to determine formation contacts but can discern differences in sediment lithology. Moreover, differences in sediment lithology that affect their hydraulic properties are of primary importance for characterizing groundwater systems.

Accordingly, the geologic units are designated primarily on the basis of distinct sediment lithologies that are generally typical of their corresponding geologic formations and have assigned their names. Stratigraphic contacts among the geologic units, however, are not everywhere identical to those among the formally recognized geologic formations. Where known or suspected, differences from recognized formations are noted among individual descriptions of the geologic units.

\section{Nanjemoy Formation Potapaco Member}

Within the study area, fine-grained sediments of the Potapaco Member of the Nanjemoy Formation underlie and form the base of the Piney Point aquifer. The Nanjemoy Formation Potapaco Member along with the deeper Marlboro Clay are together hydrologically designated as the Nanjemoy-Marlboro confining unit (fig. 3, left side) (McFarland and Bruce, 2006). Most of the Piney Point aquifer outside the study area is also underlain by the Nanjemoy-Marlboro confining unit, which is as thick as several tens of feet or more at depths as much as several hundred feet (fig. 2). The Nanjemoy-Marlboro confining unit functions hydraulically as a continuous medium that regionally impedes horizontal flow but allows relatively slow, vertical groundwater movement as leakage between overlying and underlying aquifers.

The Nanjemoy Formation Potapaco Member is composed of early Eocene-age, marine, silty and clayey, fine- to mediumgrained glauconite and quartz sand (figs. 4 and 5). Sediment core and drill cuttings exhibit colors varying among greenish black (10G 2.5/1; Munsell Color, 1998), very dark gray (5Y 3/1), dark olive gray (5Y 3/2), greenish gray (10Y 5/1), and dark greenish gray (5GY $3 / 1$ and $10 \mathrm{GY} 4 / 1)$. Borehole resistivity logs generally exhibit a relatively flat signature typical of fine-grained sediments with some variation resulting from differences in silt and (or) clay content (figs. 4 and 5, plate 2).

The top surface of the Nanjemoy Formation Potapaco Member, and therefore the base of the Piney Point aquifer, dips eastward (fig. 6; plate 2, sections $A-A^{\prime}$ and $B-B^{\prime}$ ). The top-surface altitude within the study area ranges from $22 \mathrm{ft}$ at borehole 53K 21 in New Kent County to $-516 \mathrm{ft}$ at borehole 60L 21 in Northumberland County. The configuration of the top surface is further affected by faults (see section "Faults").

Exclusive of the Chesapeake Bay impact crater, sediments of the Nanjemoy Formation Potapaco Member span the entire study area and beyond. Top-surface altitude contours, however, are drawn for this study only as far as the extent of boreholes located within the study area. The Nanjemoy Formation Potapaco Member is absent in several boreholes in Gloucester and Middlesex Counties in proximity to the impact crater (fig. 6) and is truncated in the same area by a resurge channel associated with the impact crater (plate 2, section $B-B^{\prime}$ ) (see section "Impact-Crater Resurge Channel"). The Nanjemoy Formation Potapaco Member originally spanned at least part of the area of the impact crater but was excavated during the impact event (Powars and Bruce, 1999). Disrupted clasts of the Nanjemoy Formation Potapaco Member are common throughout sediments that now fill the impact crater.

\section{Nanjemoy Formation Woodstock Member}

Within the study area, coarse-grained sediments of the Woodstock Member of the Nanjemoy Formation form the lowermost part of the Piney Point aquifer (fig. 3, right side). The Nanjemoy Formation Woodstock Member is composed of early Eocene-age, marine, variably shelly and pebbly, medium- to coarse-grained quartz and glauconite sand (figs. 4 and 5). Sediment core and drill cuttings exhibit colors varying among greenish gray (10Y 5/1), light greenish 


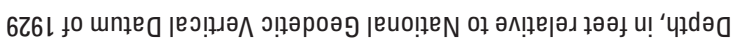

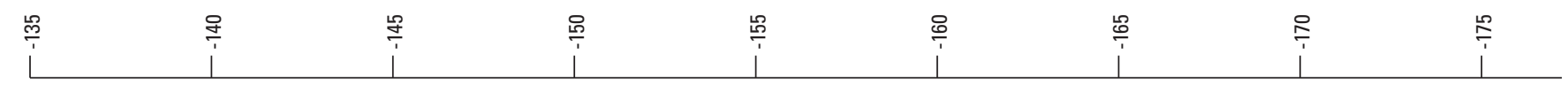

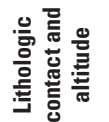

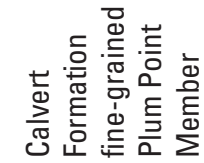

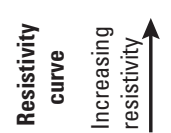

을

产
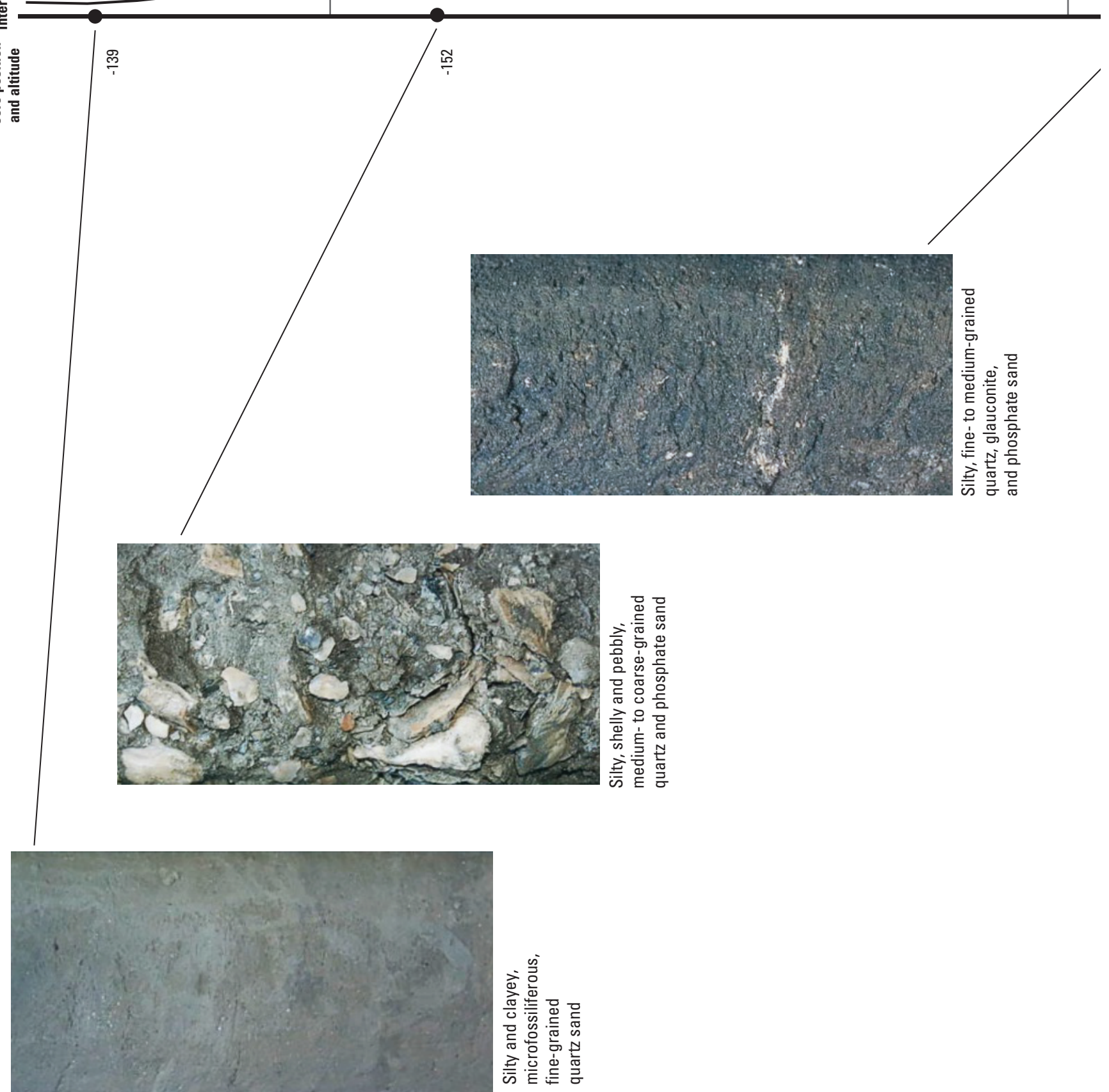


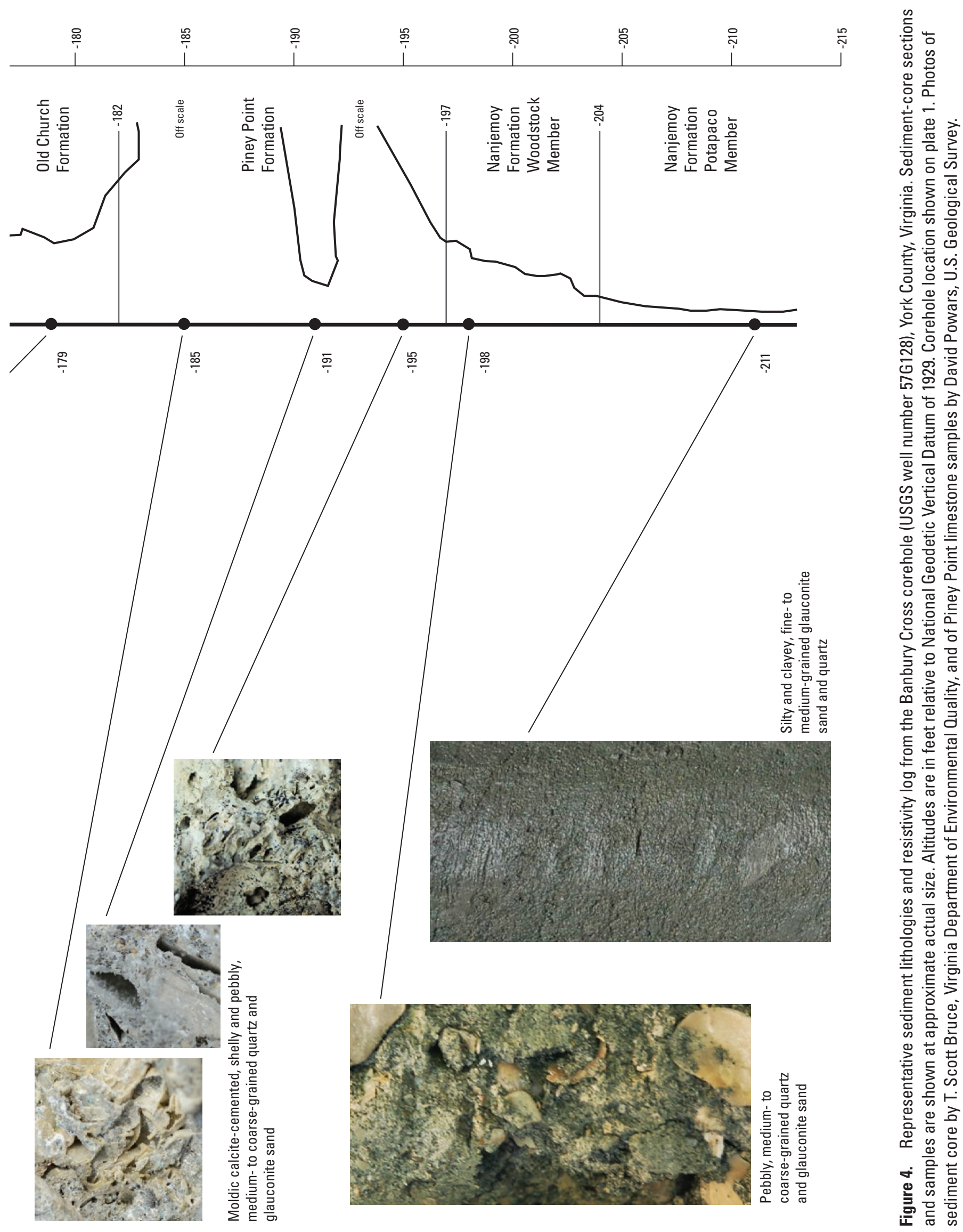




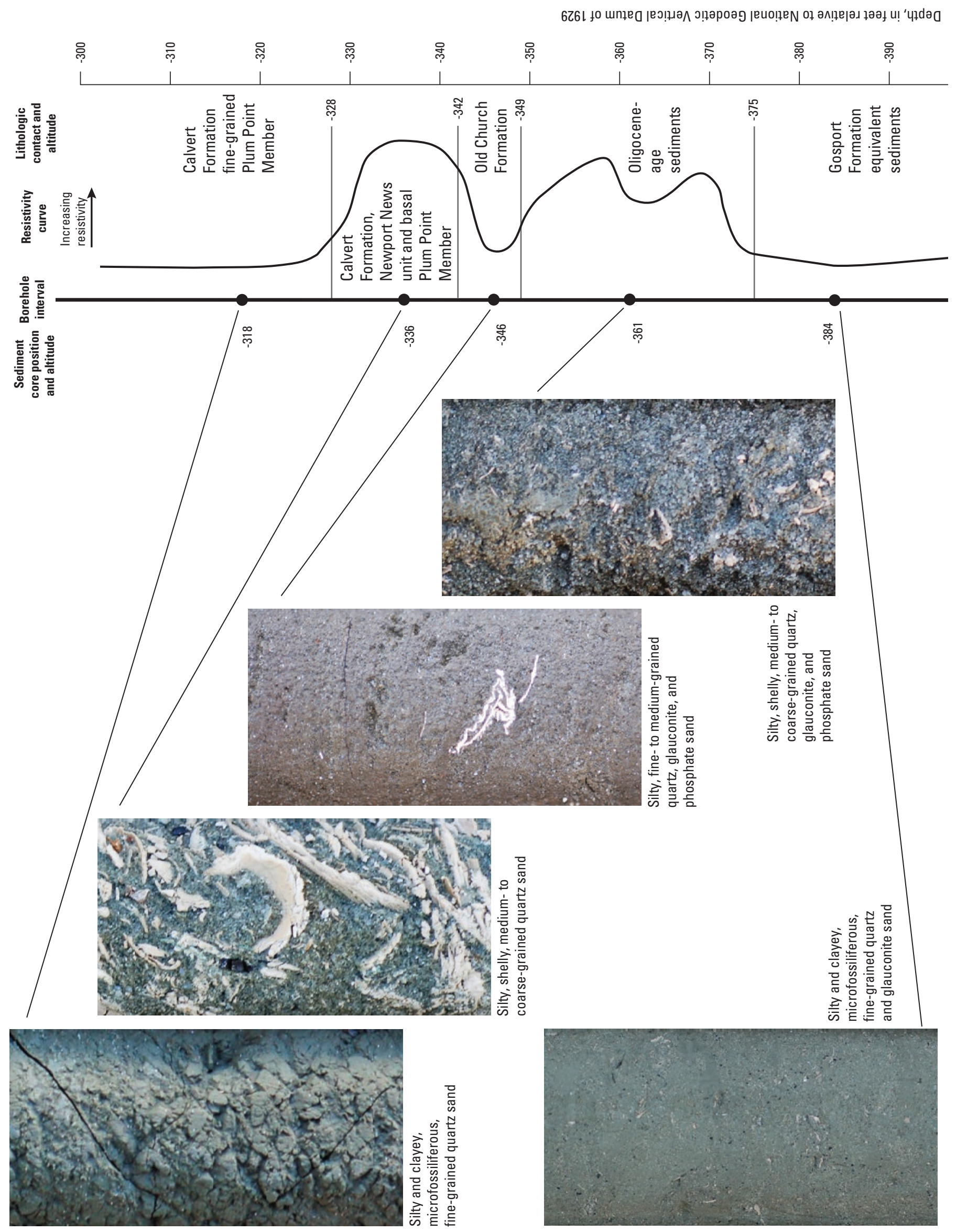



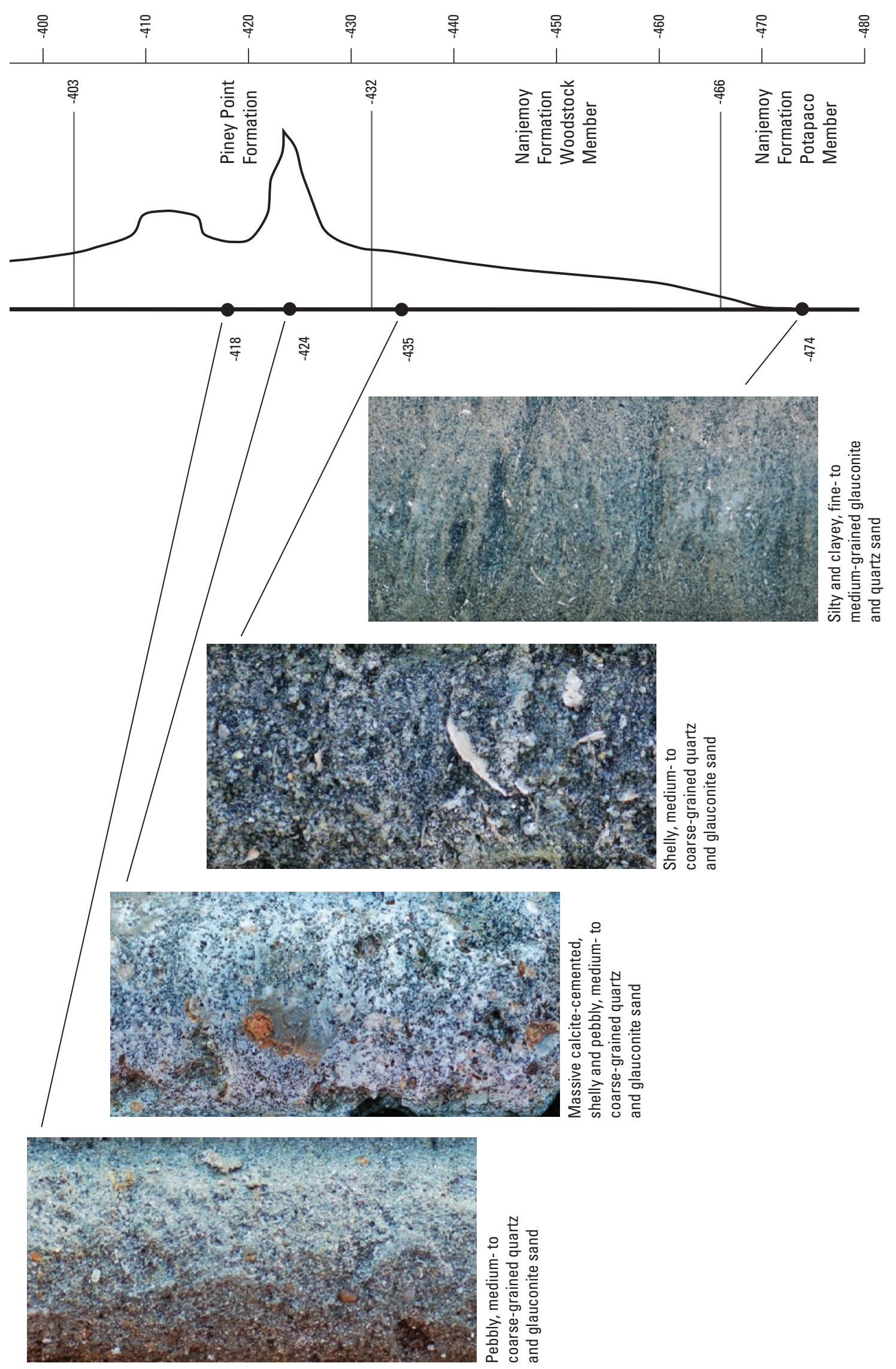


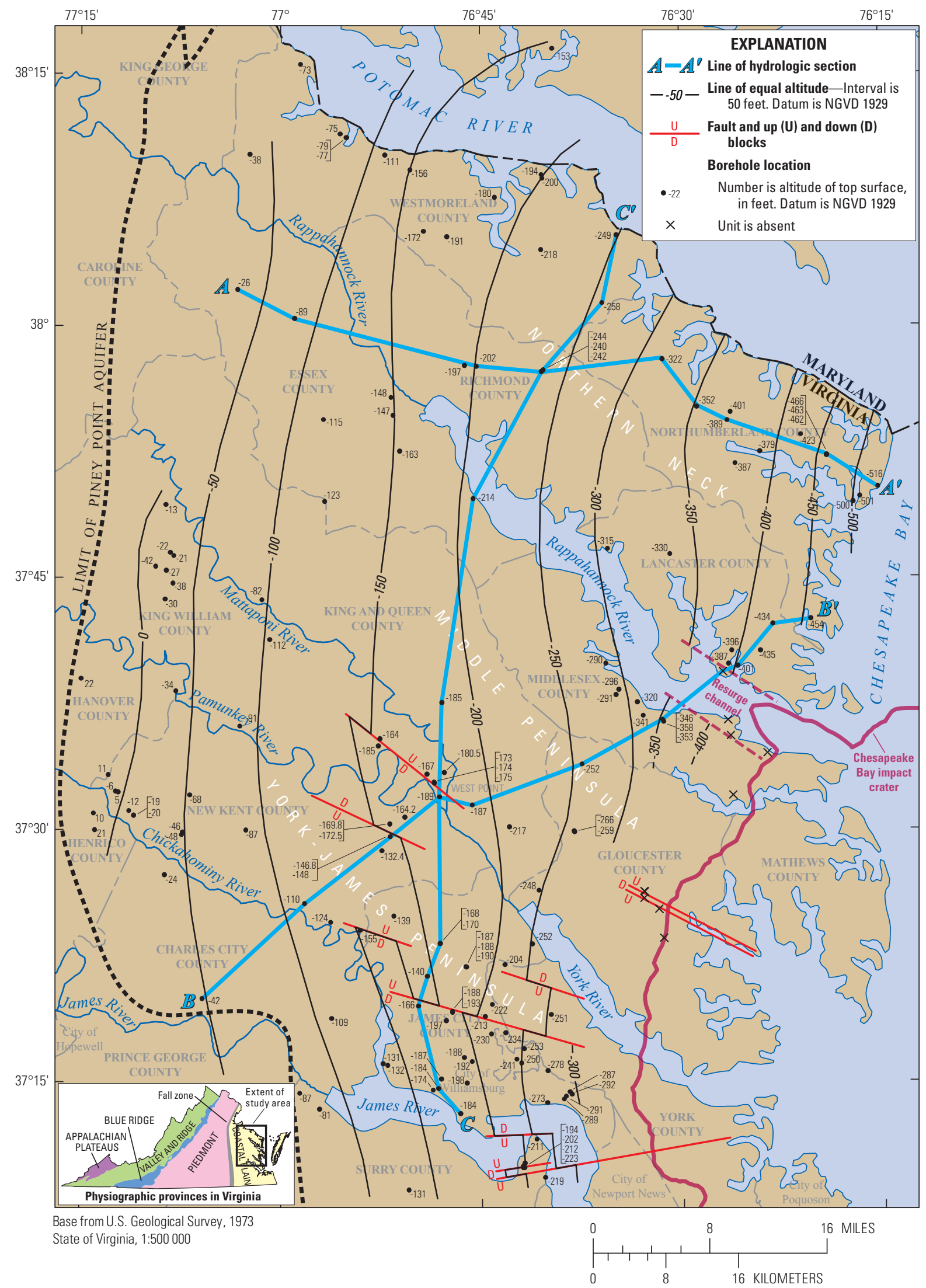

Figure 6. Altitude and configuration of the top surface of the Nanjemoy Formation Potapaco Member across the Northern Neck, upper Middle Peninsula, and upper York-James Peninsula in Virginia. 
gray (10GY 7/1), light brownish gray (10YR 6/2), and light olive (10Y 5/4). Borehole resistivity logs generally exhibit an upward increasing signature that indicates a coarseningupward texture (figs. 4 and 5; plate 2). Some sediments included here possibly are overlying sand of the lowermost part of the Piney Point Formation that is not interbedded with limestone (see section "Piney Point Formation") and is contiguous with the Nanjemoy Formation Woodstock Member.

The top surface of the Nanjemoy Formation Woodstock Member dips eastward (fig. 7; plate 2, sections $A-A^{\prime}$ and $\left.B-B^{\prime}\right)$. Top-surface altitude within the study area ranges from $48 \mathrm{ft}$ at borehole 53K 21 in New Kent County to $-493 \mathrm{ft}$ at borehole 60L 21 in Northumberland County. The thickness of the Nanjemoy Formation Woodstock Member ranges from 0 to more than $30 \mathrm{ft}$ but in most boreholes is between 10 and $20 \mathrm{ft}$ (plate 2). The configuration of the Nanjemoy Formation Woodstock Member is further affected by faults (see section "Faults").

Exclusive of the Chesapeake Bay impact crater, sediments of the Nanjemoy Formation Woodstock Member span most of the study area. The Nanjemoy Formation Woodstock Member is absent in several boreholes in Gloucester and Middlesex Counties in proximity to the impact crater (fig. 7) and is truncated in the same area by a resurge channel associated with the impact crater (plate 2, section $B-B^{\prime}$ ) (see section "Impact-Crater Resurge Channel"). The Nanjemoy Formation Woodstock Member originally spanned at least part of the area of the impact crater but was excavated during the impact event (Powars and Bruce, 1999).

The Nanjemoy Formation Woodstock Member is also absent in borehole 54G 10 in Charles City County (fig. 7) where it pinches out southeastward (plate 2, section $B-B^{\prime}$ ). At borehole 54G 10, the Piney Point aquifer is composed of only the Calvert Formation, Newport News unit and basal Plum Point Member. The Nanjemoy Formation Woodstock Member is also absent in several boreholes to the north in eastern Westmoreland County and Maryland, and to the south in Surry County. Continuity of the Nanjemoy Formation Woodstock Member to the north and south of the study area is uncertain.

\section{Piney Point Formation}

Within the study area, coarse-grained sediments of the Piney Point Formation form the next to lowest part of the Piney Point aquifer (fig. 3, right side), from which most groundwater from the aquifer is withdrawn. The Piney Point Formation is composed of middle Eocene-age, marine, variably shelly, pebbly, and calcite-cemented, medium- to coarsegrained quartz and glauconite sand (figs. 4 and 5). Sediment core and drill cuttings exhibit colors ranging from greenish gray (10Y 5/1) and light bluish gray (5B 7/1 and 10B 7/1) to yellow $(2.5 \mathrm{Y} 7 / 6)$ and olive yellow (2.5Y 6/6). Borehole resistivity logs exhibit an elevated signature typical of coarsegrained sediments with some variation resulting from differences in sand texture and (or) degree of cementation (figs. 4 and 5; plate 2). Resistivity on some logs extends off the scale.
The top surface of the Piney Point Formation dips eastward (fig. 8; plate 2, sections $A-A^{\prime}$ and $B-B^{\prime}$ ). Top-surface altitude within the study area ranges from $53 \mathrm{ft}$ at borehole 53H 13 in Henrico County to $-479 \mathrm{ft}$ at borehole 60L 21 in Northumberland County. Thickness of the Piney Point Formation ranges from 0 to nearly $50 \mathrm{ft}$, but in most boreholes is between 20 and $40 \mathrm{ft}$ (plate 2). The configuration of the Piney Point Formation is further affected by faults (see section "Faults").

Exclusive of the Chesapeake Bay impact crater, sediments of the Piney Point Formation span most of the study area. The Piney Point Formation is absent in several boreholes in Gloucester and Middlesex Counties in proximity to the impact crater (fig. 8) and is truncated in the same area by a resurge channel associated with the impact crater (plate 2, section $B-B$ ') (see section "Impact-Crater Resurge Channel"). The Piney Point Formation originally spanned at least part of the area of the impact crater but was excavated during the impact event (Powars and Bruce, 1999). Disrupted clasts of the Piney Point Formation, including limestone, are common throughout sediments that now fill the impact crater.

The Piney Point Formation is also absent in several boreholes in northwestern Westmoreland and Essex Counties (fig. 8) where it pinches out westward (plate 2, section $A-A$ ). Here the Piney Point aquifer is composed of only the Calvert Formation, Newport News unit and basal Plum Point Member, and the Nanjemoy Formation Woodstock Member. The Piney Point Formation also is absent in borehole 54G 10 in Charles City County where it pinches out southeastward (plate 2, section $B-B^{\prime}$ ). At borehole $54 \mathrm{G} 10$, the Piney Point aquifer is composed of only the Calvert Formation, Newport News unit and basal Plum Point Member.

\section{Composition of Limestone}

Unique to the Piney Point Formation, calcite cementation that is well developed forms substantial intervals of indurated limestone. Cementation also can be present in other geologic units but is generally isolated in single beds, commonly referred to as "ledges." Limestone in the Piney Point Formation exhibits either a highly porous solution-channeled moldic structure (fig. 4, fig. $9 \mathrm{~A}$, left side) or a low-porosity massive structure (fig. 5 , fig. $9 \mathrm{~A}$, right side). Production wells completed in moldic limestone yield as much as $400 \mathrm{gal} / \mathrm{min}$; massive limestone probably accounts for other wells having considerably lower yields. The limestone is commonly interbedded with uncemented sand (fig. 9B). Where limestone intervals are sufficiently thick and structurally competent, some production wells have been completed below their casings as open boreholes in the limestone, commonly referred to as "barefoot" wells. By contrast, where cementation has not developed, limestone is absent from the Piney Point Formation, which consists entirely of uncemented sand in which wells must be screened. Some uncemented sand of the lowermost part of the Piney Point Formation that is not interbedded with limestone possibly is included in the underlying Nanje- 


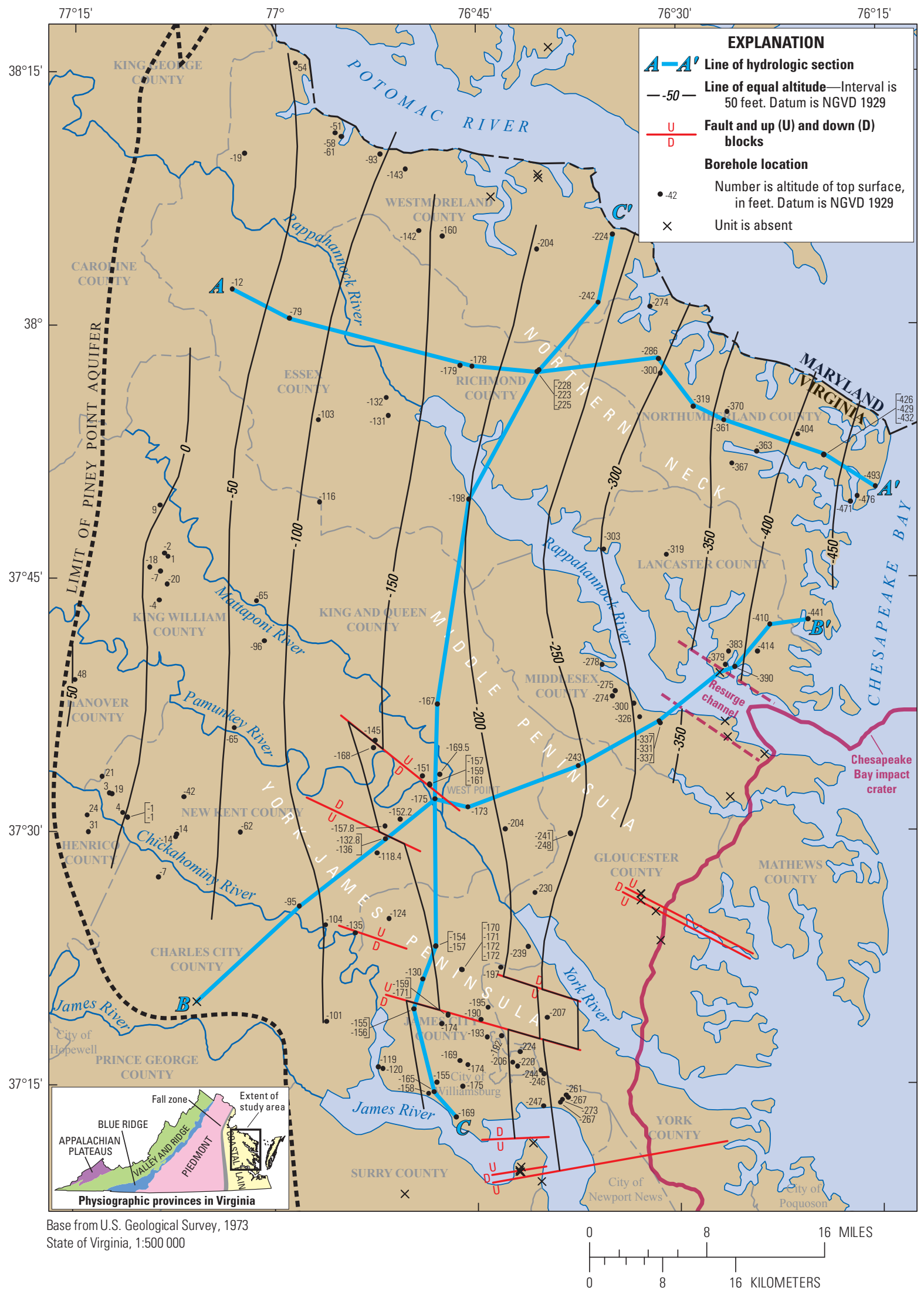

Figure 7. Altitude and configuration of the top surface of the Nanjemoy Formation Woodstock Member across the Northern Neck, upper Middle Peninsula, and upper York-James Peninsula in Virginia. 


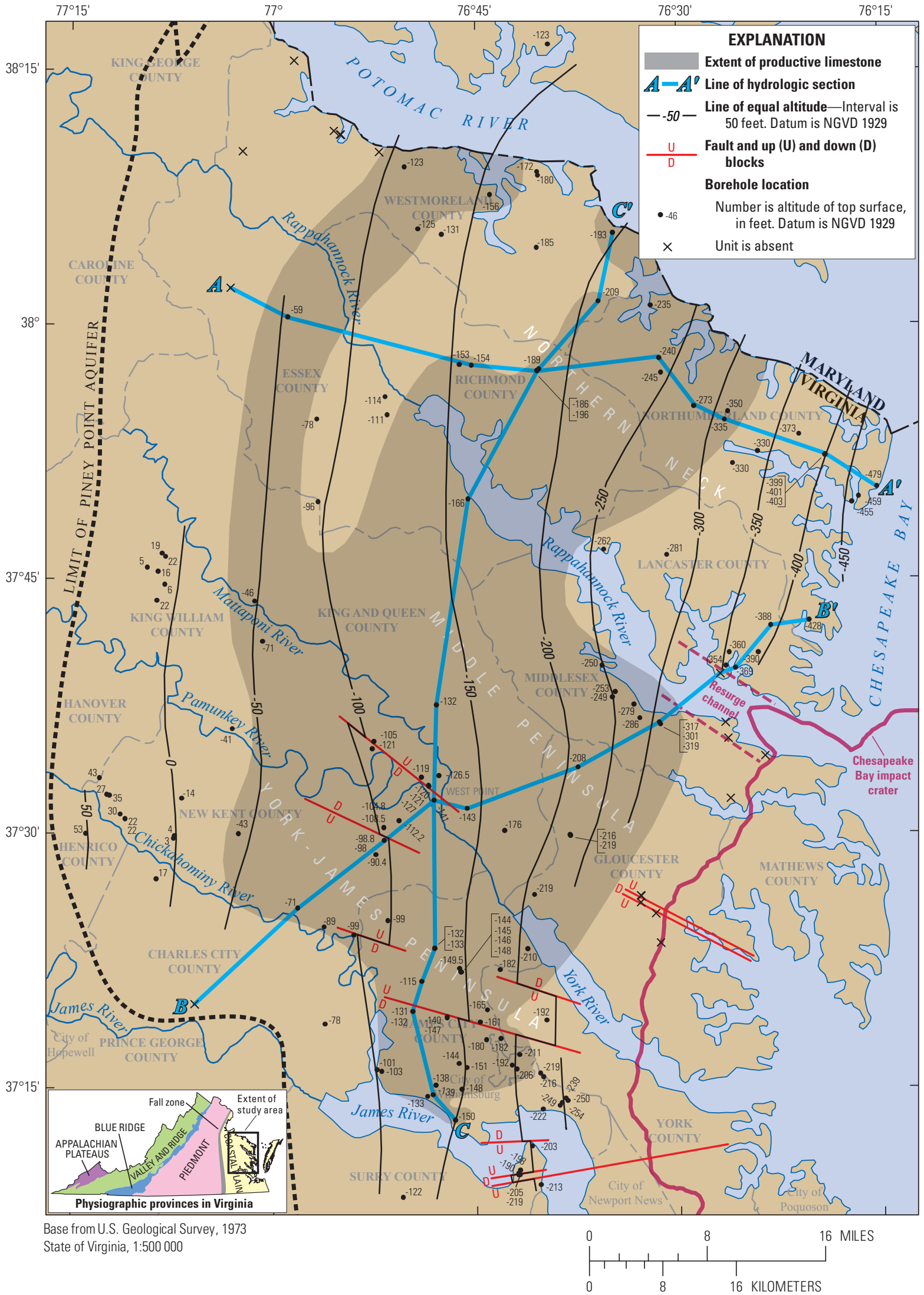

Figure 8. Altitude and configuration of the top surface of the Piney Point Formation across the Northern Neck, upper Middle Peninsula, and upper York-James Peninsula in Virginia. 
$\boldsymbol{A}$

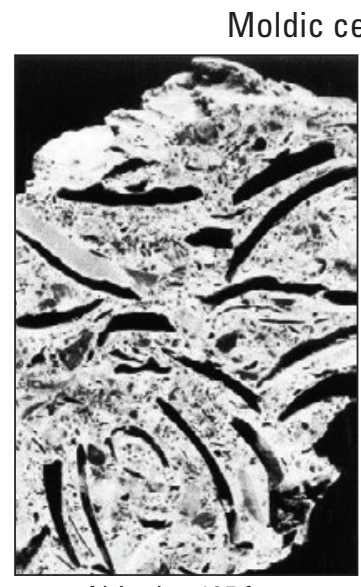

Altitude: -195 feet

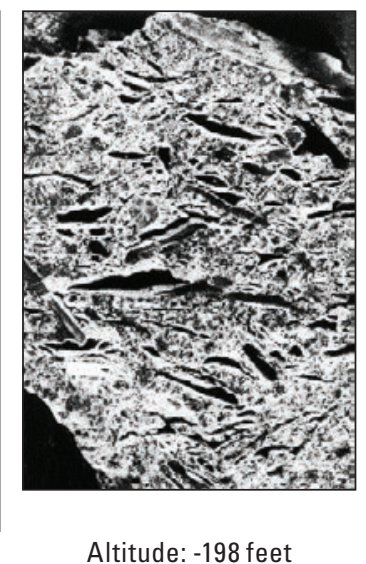

Altitude: -198 feet

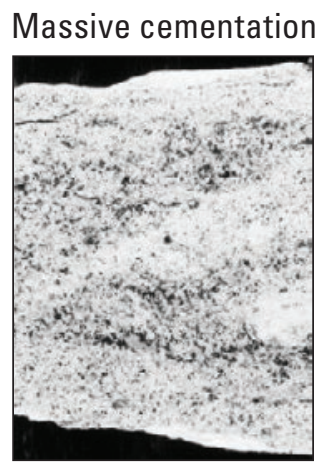

Altitude: -196 feet

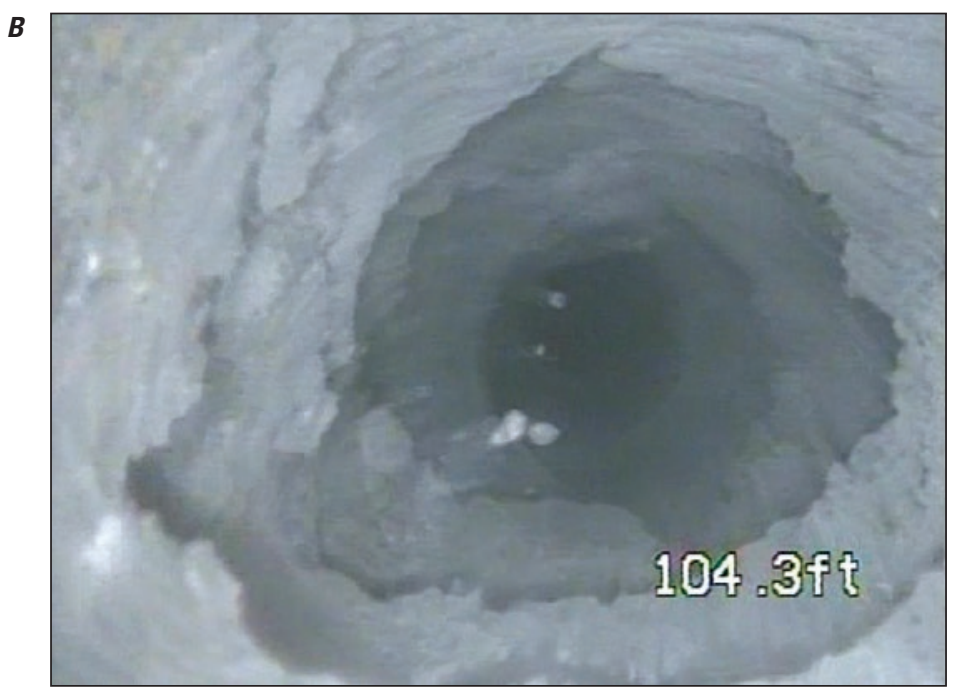

Figure 9. Representative examples of limestone of the Piney Point Formation in Virginia. $A$, Contrasting cementation among slabbed samples from Haynesville borehole 57M 7, Richmond County, Virginia (from Mixon and others, 1989). Examples are shown at approximately actual size. $B$, Photograph from video log of open-hole "barefoot" borehole 55H 30, New Kent County, Virginia. View is downward from altitude -92 feet relative to the National Geodetic Vertical Datum of 1929. Depth below land surface is shown on the photo. Borehole diameter is approximately 4 inches. Drilled limestone ledges alternate with beds of unconsolidated sand to form a counterclockwise corkscrew pattern along the borehole wall. Video logging performed by the Virginia Department of Environmental Quality. Borehole locations are shown on plate 1. moy Formation Woodstock Member (see section "Nanjemoy Formation Woodstock Member"). Conversely, some overlying sand of the lowermost part of the Old Church Formation possibly is included in the Piney Point Formation (see section "Old Church Formation").

Petrographic analyses of limestone of the Piney Point Formation were performed by John Haynes at James Madison University, Department of Geology and Environmental Science. Thin sections were fabricated of limestone samples collected at altitudes from $-185 \mathrm{ft}$ to $-192 \mathrm{ft}$ in the Banbury Cross corehole (USGS well number 57G128; plate 1; Appendix 1; McFarland, 2017) from which a continuous sediment core was obtained by the VA DEQ during 2014. Examination of hand specimens and thin sections produced the following descrip- tion of the limestone (J.T. Haynes, James Madison University, written commun., 2016):

Textures of hand samples are medium to very coarse grained, with many shell fragments reaching or exceeding 1 inch (in.) in the long dimension. Thin sections exhibit impure limestones including bioclastic grainstones and packstones, with very minor areas of patchy wackestones. Non-carbonate framework grains and cements are variable but compose less than 50 percent of the sample. Framework grains consist of various aluminosilicate and phosphate minerals subordinate to abundant calcareous bioclasts. 
Principal framework grains are pelecypod fragments (70 to 75 percent of the framework grain population), monocrystalline quartz (5 to 10 percent), glauconite and collophane (5 to 10 percent), ostacode fragments ( 1 to 3 percent), polycrystalline quartz including some that are extensively fractured ( 1 to 3 percent), and bioclastic debris including bryozoans, calcareous algae, echinoderms, gastropods, and forams (1 to 3 percent). A few large bioclasts are broken in one or more places, probably as a result of reworking by currents subsequent to death of the organism and disarticulation. Some small bioclasts are also fragmental, but unbroken and nearly whole forams, gastropods, and bryozoans are present as well. Quartz, glauconite, and collophane grains are subangular to rounded, indicating moderate to extensive transport and reworking in the marine environment. Packing of quartz, glauconite, and collophane grains is minimal, and many grains appear to be matrix supported rather than grain supported. Minimal compaction possibly was followed by relatively early cementation.

Ferroan and non-ferroan calcite and dolomite were differentiated in thin section by staining using the standard procedure of Dickson (1965). Most framework grains are cemented by equant to sub-equant sparry non-ferroan calcite or by isopachous non-ferroan calcite. Equant to sub-equant sparry calcite has also partly to completely replaced the original shell structure of much of the pelecypod bioclastic debris. The matrix consists of micrite and a few patchy areas with a small percentage of aluminosilicate clay minerals (based on the brown color of these regions). This matrix of mixed carbonate and likely sparse aluminosilicate minerals acts as a cement. Other secondary cement minerals include pyrite as cubes and framboids that partly to nearly completely replace some glauconite grains. Pyrite is abundant to numerous as small matrix-supported grains in micrite, and as variably sized grains in some large biomoldic pores that developed as pelecypod fragments were dissolved or destroyed.

Porosity is predominantly biomoldic and relatively abundant. Most large pores are partly to completely dissolved or destroyed pelecypod fragments. Some biomoldic pores are rimmed with crusts of isopachous non-ferroan calcite. Some of the distinctive reticulate pores of the original stereomic microstructure in a few echinoderm fragments have been filled by glauconite. Many glauconite grains also exhibit sparse to abundant grain moldic porosity. Minor fracture porosity is also present. A few collophane grains have complex internal structure, including fractures that have been reduced - and in some grains completely filled-by glauconite. A few glauconite grains likewise have fractures that are now reduced by collophane. In some collophane grains, the fracture pattern gives the appearance of a micro-septarian nodule despite the small sand size of the grains.

\section{Extent of Limestone}

The presence of limestone within the Piney Point Formation largely determines the productivity of wells in the Piney Point aquifer. The lateral extent of the limestone, however, has been only approximately known on the basis of anecdotal experience and not delineated systematically. Moreover, the limestone is not distinguishable from uncemented sand based solely on borehole geophysical logs.

To address the above, the lateral extent of limestone in the Piney Point Formation was estimated on the basis of sediment descriptions. Drillers' logs, and geologists' logs of drill cuttings and sediment core, were examined to determine the presence or absence of limestone across corresponding intervals within each borehole within the study area (fig. 1; plate 1). An area was then delineated to represent where the limestone is relatively continuous laterally. A belt approximately 10 mi wide spans northwestern Northumberland County and southeastern Richmond and Essex Counties, and broadens to nearly $30 \mathrm{mi}$ southward across King and Queen County, Middlesex County, eastern King William and New Kent Counties, and western Gloucester County. Farther southward, laterally continuous limestone narrows to approximately $10 \mathrm{mi}$ across James City County, northernmost York County, and the City of Williamsburg. Laterally continuous limestone does not extend south of the James River.

From the main area of laterally continuous limestone, a second narrow belt approximately $5 \mathrm{mi}$ wide extends to the northwest across parts of Westmoreland, Richmond, Essex, and King and Queen Counties (fig. 1; plate 1). Delineation of this additional area, however, is based on only five boreholes that indicate the presence of limestone. Lateral continuity is less certain than for the main area.

The Piney Point Formation within the delineated areas consists mostly of limestone interbedded with uncemented sand (fig. 9B). Sediment descriptions from most boreholes within the delineated areas indicate the presence of limestone, but a minority of boreholes indicate that it is absent where cementation has not developed. Conversely, outside the delineated areas the Piney Point Formation consists mostly of uncemented sand. Most boreholes outside the delineated areas indicate that the limestone is absent, but a minority of boreholes indicate it is present at relatively isolated locations where cementation has developed. In addition, the number and density of boreholes varies and is generally smaller to the north. Given greater borehole coverage, continuous limestone would possibly have been delineated differently.

Within the delineated areas of laterally continuous limestone, the maximum altitude of the Piney Point Formation is approximately - $40 \mathrm{ft}$ (fig. 8). Hence, the limestone is entirely 
in the subsurface and does not crop out. The Piney Point Formation in Virginia is stratigraphically correlative to the Castle Hayne Formation in North Carolina (Winner and Coble, 1996). Limestone of the Castle Hayne Formation is extensively developed but is not laterally continuous with that of the Piney Point Formation in Virginia. Deposition of carbonate sediments either did not take place or was not preserved across the intervening Norfolk arch.

Limestone of the Castle Hayne Formation in North Carolina was deposited in a tropical marine environment (Baum, 1980). Limestone of the Piney Point Formation in Virginia also was probably deposited in similarly warm conditions. By contrast, farther north in Maryland the Piney Point Formation is described as a glauconitic sand (Andreasen and others, 2013). Limestone that dominates the productive part of the Piney Point aquifer in Virginia possibly is poorly developed across much of Maryland. Cold ocean temperatures north of Virginia during the Eocene Epoch possibly precluded deposition of carbonate sediments.

\section{Gosport Formation Equivalent Sediments}

Fine-grained sediments that are equivalent in age to the Gosport Formation form an intermediate part of the Piney Point aquifer (fig. 3, right side). On the basis of microfossil analysis (L.E. Edwards, U.S. Geological Survey, written commun., 2007), the presence of sediments of late middle Eocene age that are equivalent to the Gosport Formation in Georgia was determined in the Surprise Hill core (borehole 60L 22) in Northumberland County (plate 1). The Surprise Hill core is the first known presence of sediments of this age in the Virginia Coastal Plain outside of the Chesapeake Bay impact crater.

Gosport Formation equivalent sediments are composed of middle Eocene-age, marine, silty and clayey, variably microfossiliferous and pebbly, fine- to medium-grained quartz and glauconite sand (fig. 5). The Surprise Hill core exhibits a fairly uniform color of dark greenish gray (10Y 4/1). Borehole resistivity logs exhibit a uniformly flat signature typical of fine-grained sediments but with a distinctive broad U-shaped profile (fig. 5; plate 2).

The top surface of the Gosport Formation equivalent sediments dips eastward (fig. 10; plate 2, sections $A-A^{\prime}$ and $B-B^{\prime}$ ). The top-surface altitude within the study area ranges from $-274 \mathrm{ft}$ at borehole $58 \mathrm{~L} 7$ in Lancaster County to $-431 \mathrm{ft}$ at well 60L 21 in Northumberland County. Thickness of the Gosport Formation equivalent sediments ranges from 0 to approximately $50 \mathrm{ft}$, but in most boreholes is approximately $30 \mathrm{ft}$ (plate 2).

Gosport Formation equivalent sediments span only the most northeastern part of the study area on the eastern Northern Neck and in Middlesex County (fig. 10). The distinctive U-shaped profile exhibited by the resistivity log from the Surprise Hill corehole (borehole 60L 22) was correlated to resistivity logs from 21 other boreholes to infer the presence of Gosport Formation equivalent sediments. This signature does not appear on resistivity logs from boreholes located to the west where Gosport Formation equivalent sediments pinch out (plate 2, sections $A-A^{\prime}$ and $B-B^{\prime}$ ).

Gosport Formation equivalent sediments are also absent in several boreholes to the south in Gloucester and Middlesex Counties in proximity to the Chesapeake Bay impact crater (fig. 10) and are truncated by a resurge channel associated with the impact crater (plate 2, section $B-B$ ') (see section "ImpactCrater Resurge Channel"). Gosport Formation equivalent sediments possibly originally spanned at least part of the area of the impact crater but were excavated during the impact event.

Where Gosport Formation equivalent sediments are present, the Piney Point aquifer differs from elsewhere. Total thickness of the Piney Point aquifer is substantially increased (plate 2, sections $A-A^{\prime}$ and $B-B^{\prime}$ ). Moreover, the fine-grained sediments create a large vertical separation between coarsergrained underlying and overlying sediments that compose other parts of the aquifer. The Piney Point aquifer is thereby effectively divided vertically into distinct upper and lower aquifers. Conversely, where Gosport Formation equivalent sediments are absent across most of the study area, coarsegrained sediments that compose different parts of the Piney Point aquifer are in closer vertical proximity or direct contact.

\section{Oligocene-Age Sediments}

Coarse-grained sediments of Oligocene age form an intermediate part of the Piney Point aquifer (fig. 3, right side). On the basis of microfossil analysis (L.E. Edwards, U.S. Geological Survey, written commun., 2007), the presence of sediments of Oligocene age was determined in the Surprise Hill core (borehole 60L 22) in Northumberland County (plate 1). Oligocene-age sediments are composed of marine, silty, shelly, medium- to coarse-grained quartz, glauconite, and phosphate sand (fig. 5). The Surprise Hill sediment core and drill cuttings from borehole 59K 36 in Lancaster County (plate 1) exhibit colors ranging from greenish gray (5GY $5 / 1)$ to dark olive gray (5Y 3/2) and black (5Y 2.5/1 and 5Y 2.5/2). Borehole resistivity logs exhibit an elevated signature typical of coarsegrained sediments with some variation resulting from differences in sand texture and silt content. Some overlying sand of the lowermost part of the Old Church Formation possibly is included with the Oligocene-age sediments (see section "Old Church Formation"). Conversely, some Oligocene-age sediments possibly are included with the overlying Calvert Formation, Newport News unit and basal Plum Point Member (see section "Calvert Formation, Newport News unit and basal Plum Point Member").

The top surface of the Oligocene-age sediments dips eastward (fig. 11; plate 2, sections $A-A^{\prime}$ and $B-B^{\prime}$ ). The topsurface altitude within the study area ranges from $-266 \mathrm{ft}$ at borehole 58L 7 in Lancaster County to $-421 \mathrm{ft}$ at well 60L 21 in Northumberland County. The thickness of the Oligoceneage sediments ranges from 0 to more than $20 \mathrm{ft}$, but in most boreholes, it is approximately $10 \mathrm{ft}$ (plate 2).

Oligocene-age sediments span only the most northeastern part of the study area on the eastern Northern Neck and in 


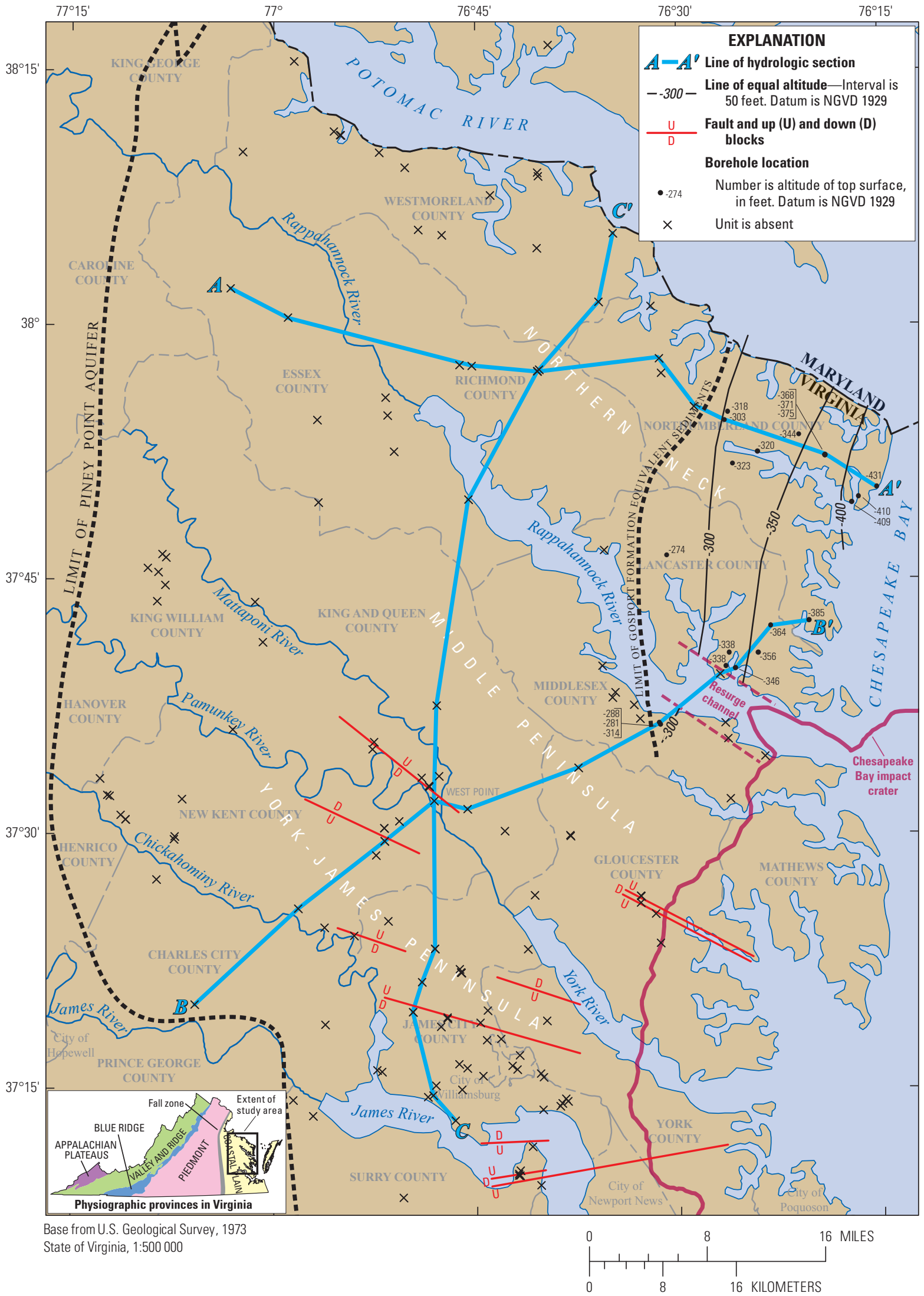

Figure 10. Altitude and configuration of the top surface of sediments equivalent to the Gosport Formation across the Northern Neck, upper Middle Peninsula, and upper York-James Peninsula in Virginia. 


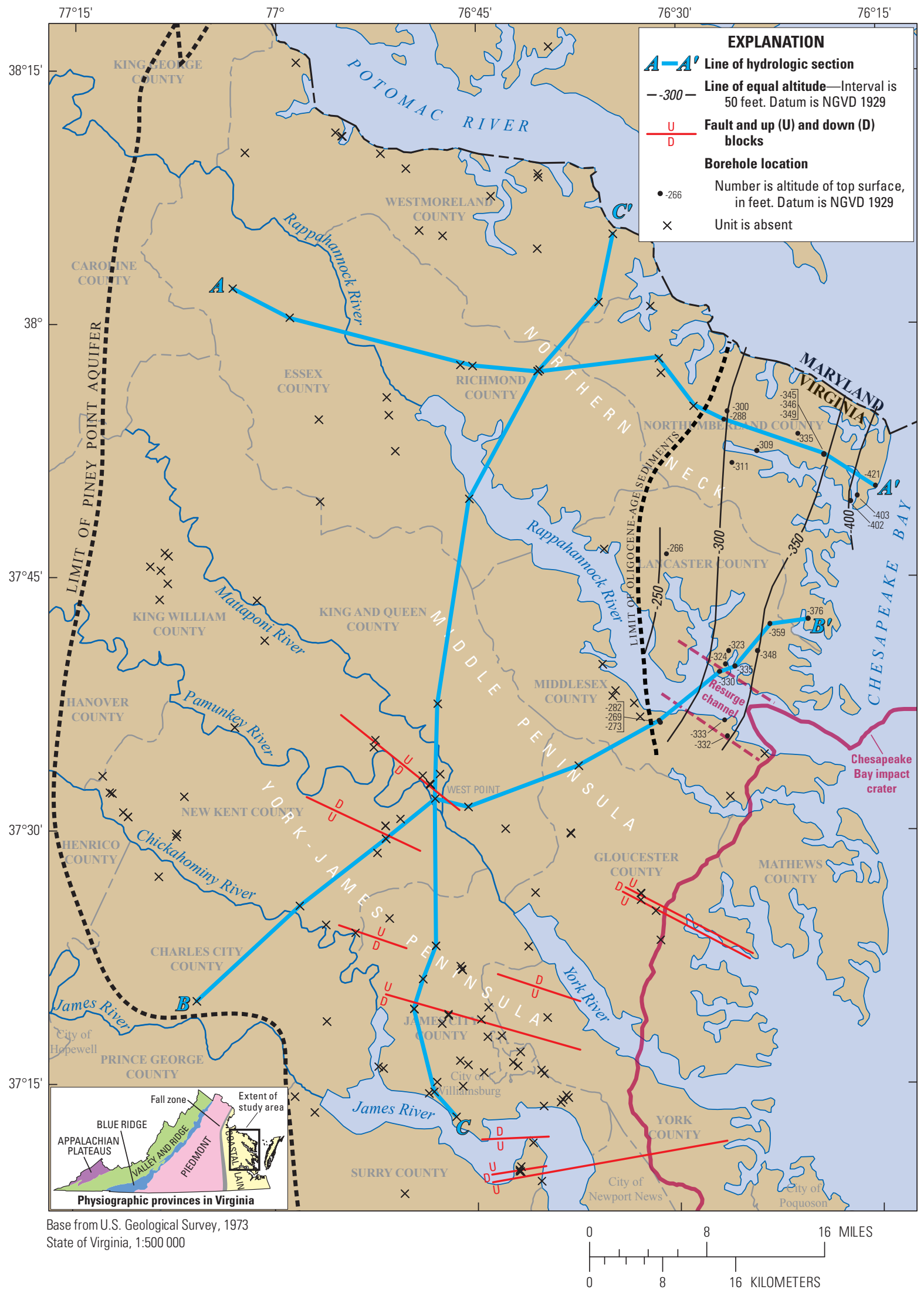

Figure 11. Altitude and configuration of the top surface of Oligocene-age sediments across the Northern Neck, upper Middle Peninsula, and upper York-James Peninsula in Virginia. 
Middlesex County (fig. 11). The corresponding interval on the resistivity log from the Surprise Hill corehole was correlated to resistivity logs from 23 other boreholes to infer the presence of Oligocene-age sediments. These intervals generally coincide with those of underlying Gosport Formation equivalent sediments, which have the same extent. The intervals do not correlate with resistivity logs from boreholes located to the west where Oligocene-age sediments pinch out (plate 2, sections $A-A^{\prime}$ and $B-B^{\prime}$ ).

Oligocene-age sediments are absent in several boreholes to the south in Gloucester and Middlesex Counties in proximity to the Chesapeake Bay impact crater (fig. 11). These sediments were deposited more recently than the impact event, however, so could not have been excavated during the impact event. If Oligocene-age sediments originally spanned part of the area of the impact crater, they possibly were not preserved. Alternatively, some part of Oligocene-age sediments that do span the area of the impact crater possibly is included here with the Calvert Formation, Newport News unit and basal Plum Point Member (see section "Calvert Formation, Newport News unit and basal Plum Point Member"). In addition, unlike underlying Gosport Formation equivalent sediments and deeper geologic units, Oligocene-age sediments are not truncated by a resurge channel associated with the impact crater (plate 2, section $B-B^{\prime}$ ) (see section "Impact-Crater Resurge Channel").

\section{Old Church Formation}

Within the study area, fine-grained sediments of the Old Church Formation form the next to highest part of the Piney Point aquifer (fig. 3, right side). The Old Church Formation is composed of late Oligocene-age, marine, silty, variably shelly and pebbly, fine-to-medium grained quartz, glauconite, and phosphate sand (figs. 4 and 5). Sediment core and drill cuttings exhibit a fairly uniform color of dark olive gray $(5 Y 3 / 2)$ to black (5Y 2.5/2). Borehole resistivity logs exhibit a uniformly flat signature typical of fine-grained sediments (figs. 4 and 5; plate 2). Some coarser-grained sand of the lowermost part of the Old Church Formation possibly is included with the underlying Oligocene-age sediments (see section "OligoceneAge Sediments"). Conversely, other coarser-grained sand of the uppermost part of the Old Church Formation possibly is included with the overlying Calvert Formation, Newport News unit and basal Plum Point Member (see section "Calvert Formation, Newport News unit and basal Plum Point Member").

The top surface of the Old Church Formation dips eastward (fig. 12; plate 2, sections $A-A^{\prime}$ and $B-B^{\prime}$ ). The top-surface altitude within the study area ranges from $50 \mathrm{ft}$ at borehole 53J 23 in Hanover County to $-405 \mathrm{ft}$ at borehole 60L 21 in Northumberland County. The thickness of the Old Church Formation ranges from 0 to nearly $20 \mathrm{ft}$, but in most boreholes is less than $10 \mathrm{ft}$ (plate 2). The configuration of the Old Church Formation is further affected by faults (see section "Faults").

Exclusive of the Chesapeake Bay impact crater, sediments of the Old Church Formation span most of the study area. Across most of the Piney Point aquifer, the fine-grained sediments create a relatively thin vertical separation between coarser-grained underlying and overlying sediments that compose other parts of the aquifer.

Fine-grained sediments of the Old Church Formation are absent in several boreholes in Gloucester and Middlesex Counties in proximity to the Chesapeake Bay impact crater (fig. 12). The Old Church Formation was deposited more recently than the impact event, however, so could not have been excavated during the impact event. If fine-grained sediments of the Old Church Formation originally spanned part of the area of the impact crater they were not preserved. Conversely, some coarser-grained sand of the Old Church Formation that does span the area of the impact crater possibly is included with the overlying Calvert Formation, Newport News unit and basal Plum Point Member (see section "Calvert Formation, Newport News unit and basal Plum Point Member"). In addition, like the underlying Oligocene-age sediments and unlike deeper geologic units, fine-grained sediments of the Old Church Formation are not truncated by a resurge channel associated with the impact crater (plate 2, section $B-B^{\prime}$ ) (see section "Impact-Crater Resurge Channel").

The Old Church Formation is also absent in several boreholes in northwestern Westmoreland and Essex Counties (fig. 12) where it pinches out westward (plate 2, section $A-A^{\prime}$ ). Here the Piney Point aquifer is composed of only the Calvert Formation, Newport News unit and basal Plum Point Member, and the Nanjemoy Formation Woodstock Member. Likewise, the Old Church Formation is absent in several boreholes in western New Kent and Charles City Counties (fig. 12) where it pinches out southeastward (plate 2, section $B-B^{\prime}$ ). Here the Piney Point aquifer is composed of only the Calvert Formation, Newport News unit and basal Plum Point Member.

\section{Calvert Formation, Newport News Unit and Basal Plum Point Member}

Coarse-grained sediments of the Calvert Formation Newport News unit and basal part of the Plum Point Member form the uppermost part of the Piney Point aquifer (fig. 3, right side). The early Miocene-age Newport News unit of the Calvert Formation is stratigraphically distinct from and lower than the middle Miocene-age Plum Point Member (Powars and Bruce, 1999). In a hydrologic context, however, the Newport News unit within the study area exhibits a similar lithology and is contiguous with directly overlying sediments of the basal part of the Plum Point Member. Accordingly, both parts of the Calvert Formation are designated here as a single geologic unit composing the uppermost part of the Piney Point aquifer. Some Oligocene-age sediments (see section "Oligocene-Age Sediments") and (or) coarser-grained sand of the Old Church Formation (see section "Old Church Formation") in proximity to the Chesapeake Bay impact crater possibly are included. The remainder of the Plum Point Member overlying its basal part consists of fine-grained sediments that are not 


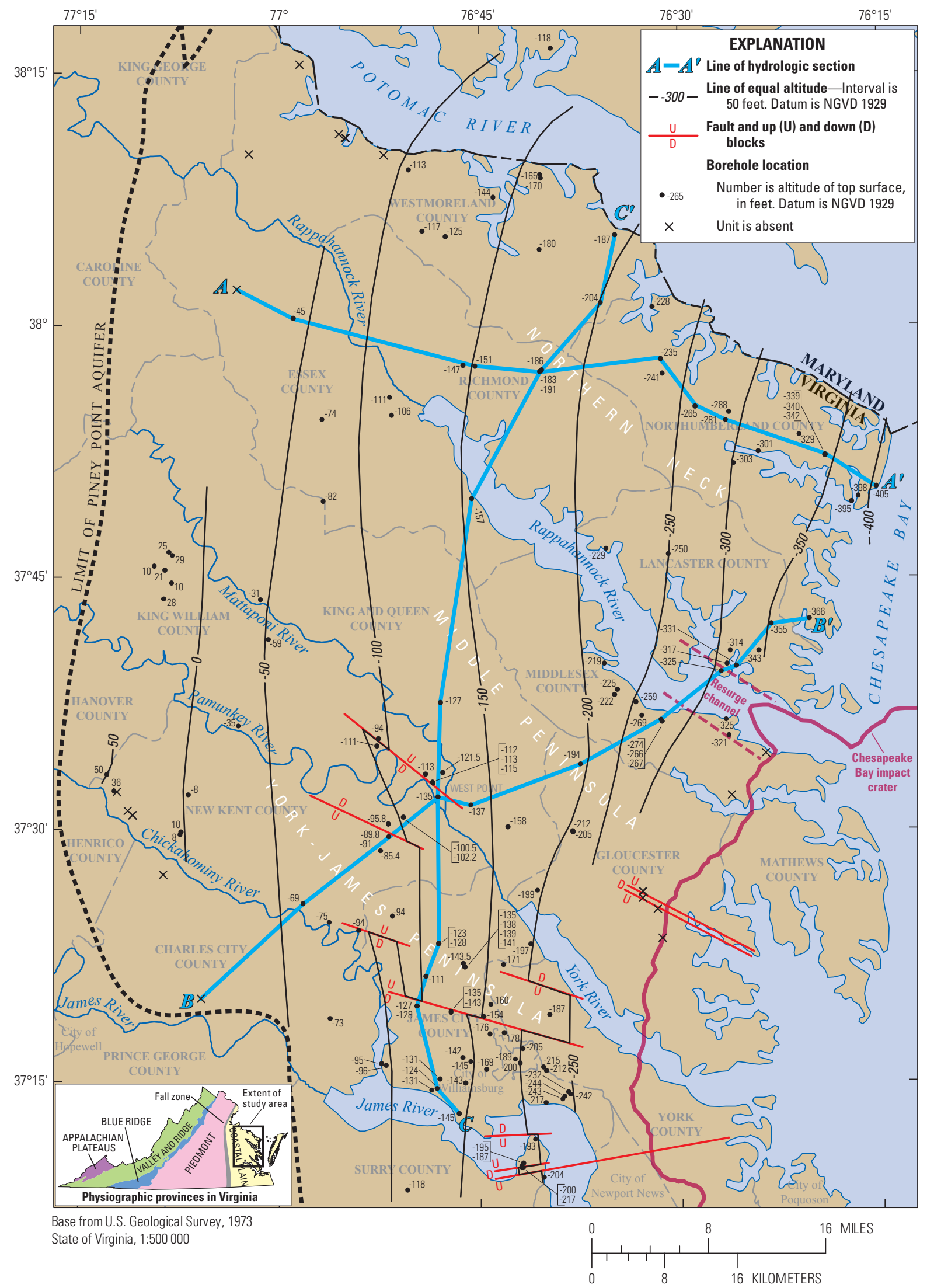

Figure 12. Altitude and configuration of the top surface of the Old Church Formation across the Northern Neck, upper Middle Peninsula, and upper York-James Peninsula in Virginia. 
part of the Piney Point aquifer, but instead partly compose the Calvert confining unit (see section "Calvert Formation FineGrained Plum Point Member").

The Calvert Formation, Newport News unit and basal Plum Point Member are composed of early and middle Miocene-age, marine, silty, variably shelly and pebbly, mediumto coarse-grained quartz and phosphate sand (figs. 4 and 5). Sediment core and drill cuttings exhibit colors ranging from greenish gray (5GY 5/1 and $10 \mathrm{Y} 5 / 1)$ and dark greenish gray (10Y 3/2) to olive (5Y 5/3, $5 \mathrm{Y} 4 / 3$, and $5 \mathrm{Y} 4 / 4)$, olive brown $(2.5 \mathrm{Y} 4 / 3)$, olive gray $(5 \mathrm{Y} 4 / 2)$, dark olive gray $(5 \mathrm{Y} 3 / 2)$, very dark grayish brown (2.5Y 3/2), and black 5Y 2.5/2. Borehole resistivity logs exhibit an elevated signature typical of coarsegrained sediments with some variation resulting from differences in sand texture and silt content.

The top surface of the Calvert Formation, Newport News unit and basal Plum Point Member dips eastward (fig. 13; plate 2 , sections $A-A^{\prime}$ and $\left.B-B^{\prime}\right)$. The top-surface altitude within the study area ranges from $60 \mathrm{ft}$ at borehole 53J 23 in Hanover County to $-405 \mathrm{ft}$ at borehole 59J 11 in Middlesex County. The thickness of the Calvert Formation, Newport News unit and basal Plum Point Member ranges from less than $20 \mathrm{ft}$ to more than $40 \mathrm{ft}$, but in most boreholes is approximately $20 \mathrm{ft}$ (plate 2). The configuration of the Calvert Formation, Newport News unit and basal Plum Point Member is further affected by faults (see section "Faults").

The Calvert Formation, Newport News unit and basal Plum Point Member uniquely spans the entire study area and beyond (fig. 13). The top-surface altitude contours, however, are drawn for this study only as far as the extent of boreholes located within the study area. Where other geologic units that compose the Piney Point aquifer are present, the Calvert Formation, Newport News unit and basal Plum Point Member forms the uppermost part of the aquifer. In several boreholes in northwestern Westmoreland and Essex Counties, however, the Piney Point aquifer is composed of only the Calvert Formation, Newport News unit and basal Plum Point Member, along with the Nanjemoy Formation Woodstock Member, because other geologic units have pinched out (plate 2, section $A-A^{\prime}$ ). Likewise, in several boreholes in western New Kent and Charles City Counties, the Piney Point aquifer is entirely composed of the Calvert Formation, Newport News unit and basal Plum Point Member (fig. 13) where all other geologic units have pinched out (plate 2, section $B-B^{\prime}$ ).

More broadly the Calvert Formation, Newport News unit and basal Plum Point Member entirely composes much of the Piney Point aquifer outside of the study area, including across the Chesapeake Bay impact crater (figs. 1 and 2). The Calvert Formation, Newport News unit and basal Plum Point Member was deposited more recently than the impact event so was not excavated during the impact event. Also like the underlying Old Church Formation and Oligocene-age sediments, and unlike deeper geologic units, the Calvert Formation, Newport News unit and basal Plum Point Member is not truncated by a resurge channel associated with the impact crater (plate 2, section $B-B$ ) (see section "Impact-Crater Resurge Channel").

\section{Fine-Grained Calvert Formation Plum Point Member}

Within the study area, fine-grained sediments of the Plum Point Member of the Calvert Formation overlie the Piney Point aquifer. These sediments are distinct from the coarsergrained basal part of the Plum Point Member that along with the Newport News unit forms the uppermost part of the Piney Point aquifer. The fine-grained Plum Point Member and the overlying Calvert Beach Member of the Calvert Formation are together hydrologically designated as the Calvert confining unit (fig. 3, left side) (McFarland and Bruce, 2006). Most of the Piney Point aquifer outside of the study area is also overlain by the Calvert confining unit, which is as thick as a few hundred feet at depths of as much as several hundred feet (fig. 2). The Calvert confining unit functions hydraulically as a continuous medium that regionally impedes horizontal flow but allows relatively slow, vertical groundwater movement as leakage between overlying and underlying aquifers.

The Calvert Formation fine-grained Plum Point Member is composed of middle Miocene-age, marine, silty and clayey, microfossiliferous, fine-grained quartz sand (figs. 4 and 5). Shells are generally scattered, but foraminifera and diatoms are commonly abundant. Pervasive jointing, small-scale fractures, and a crumbly structure possibly enhance vertical leakage relative to other confining-unit sediments. Sediment core and drill cuttings exhibit colors, including mostly dark olive gray (5Y 3/2) and olive gray (5Y 4/2 and 5/2) but also dark gray $(5 \mathrm{Y} 4 / 1)$, gray $(5 \mathrm{Y} 5 / 1)$, dark grayish brown $(2.5 \mathrm{Y} 4 / 2)$, grayish brown (2.5Y 5/2) and dark greenish gray (5GY 4/1). Borehole resistivity logs generally exhibit a relatively flat signature typical of fine-grained sediments (figs. 4 and 5; plate 2) with some moderate and generally isolated peaks resulting from interbedded shells.

Sediments of the fine-grained Calvert Formation Plum Point Member span the entire study area and beyond. Together with the Calvert Beach Member, the configuration of the Calvert confining unit has been previously mapped across the entire Virginia Coastal Plain (McFarland and Bruce, 2006) and is not duplicated here.

\section{Structural Configuration}

All geologic units that compose the Piney Point aquifer dip to the east (see section "Geologic Units"). Only the Calvert Formation, Newport News unit and basal Plum Point Member that forms the uppermost part of the Piney Point aquifer spans the entire study area. In proximity to the Chesapeake Bay impact crater, underlying geologic units were either excavated during the impact event or have not been preserved. In addition, the Nanjemoy Formation Woodstock Member, Piney Point Formation, and Old Church Formation pinch out to the northwest in Westmoreland and Essex Counties (plate 2, section $A-A^{\prime}$ ) and (or) to the southwest in New Kent and Charles City Counties (plate 2 section $B-B^{\prime}$ ). Gosport Forma- 


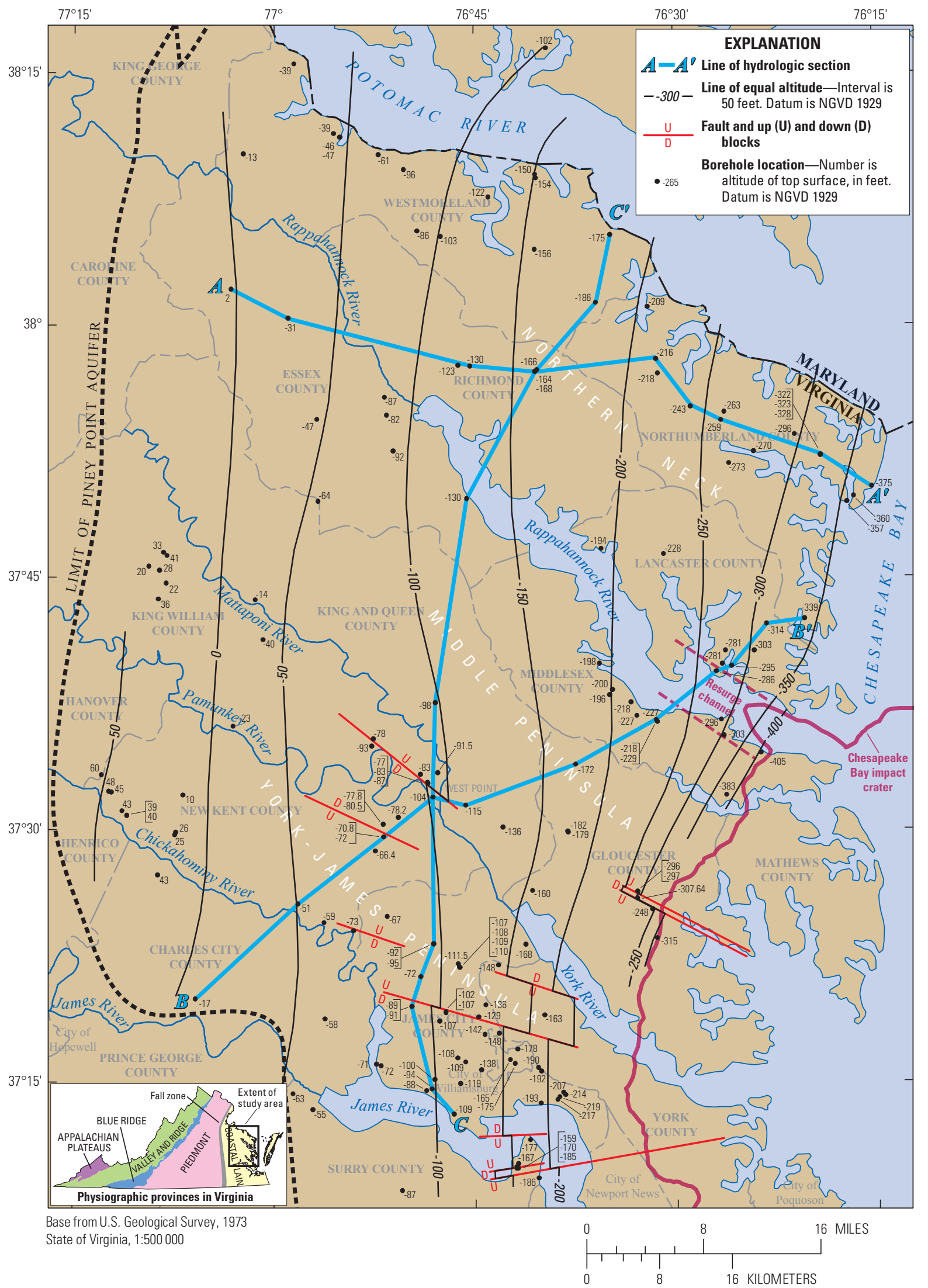

Figure 13. Altitude and configuration of the top surface of the Calvert Formation, Newport News unit and basal Plum Point Member across the Northern Neck, upper Middle Peninsula, and upper York-James Peninsula in Virginia. 
tion equivalent sediments and Oligocene-age sediments are limited to the northeast on the Northern Neck and in Middlesex County, and pinch out to the west. The configurations of most of the geologic units are further affected by faults and by a resurge channel associated with the impact crater.

\section{Faults}

Altitudes of most of the geologic units within the study area are offset by a series of faults (figs. 6-8, 12, and 13; plate 2). Faults have not been recognized, however, across the limited area spanned by the Gosport Formation equivalent sediments and the Oligocene-age sediments (figs. 10 and 11).

Alignments of high-angle to vertical faults that intercept the geologic units were interpreted from borehole geophysical logs and associated stratigraphic correlation and structure-contour mapping. The faults are inferred to account for localized vertical displacements of geologic-unit top surfaces of $30 \mathrm{ft}$ or more among closely spaced boreholes. These displacements contrast sharply with the broadly uniform configurations of the geologic-unit top surfaces exhibited regionally. Potentially many more faults are present but have not been recognized because of sparse borehole data and inadequate spatial control.

Within the study area, three relatively long faults that extend into the Chesapeake Bay impact crater were previously delineated (McFarland and Bruce, 2006). Two of the previously delineated faults are in Gloucester County and form a closely spaced parallel pair (figs. 6-8, 12, and 13). These faults vertically displace sediments that compose the Potomac aquifer by more than $500 \mathrm{ft}$ and have been theorized to form a deep narrow graben associated with the impact crater. The Piney Point aquifer here is composed solely of the Calvert Formation, Newport News unit and basal Plum Point Member because all other geologic units were either excavated during the impact event or have not been preserved (see section "Geologic Units"). The top surface of the Calvert Formation, Newport News unit and basal Plum Point Member is vertically offset across these faults by more than $50 \mathrm{ft}$ (fig. 13).

The other previously delineated fault was originally mapped from southern York County westward across the city of Newport News and beneath the James River (McFarland and Bruce, 2006). On the basis of interpretation of additional borehole geophysical logs for this study, this fault extends farther west across northeastern Surry County (figs. 6-8, 12, and 13) and is closely associated with two newly delineated faults.

For this study, seven relatively short faults were newly delineated across the York-James Peninsula and southward beneath the James River and across northeastern Surry County (figs. 6-8, 12, and 13; plate 2). The newly delineated faults form sets that define distinct structures and appear to be related to some geomorphic features. The two northernmost faults in King William and New Kent Counties form a graben aligned with the Pamunkey River upstream from the town of West Point. Large river meanders developed within, and appear to be constrained by, the graben. Outside the southeastern end of the graben is also an abrupt southward turn in the Mattaponi River, resulting in its confluence with the Pamunkey River and forming the York River at West Point within the southeastern end of the graben.

Farther south in New Kent and James City Counties, a complex horst-like structure is aligned with the downstream part of the Chickahominy River and extends southeastward into northwestern York County (figs. 6-8 and 10-13). This structure is bounded on the northeast by two fault segments that together form a scissor fault, and on the southwest by another fault downthrown to the southwest. Similar to the West Point graben, this structure coincides with meanders of the Chickahominy River, along with its abrupt southward turn toward the confluence with the James River. Farthest south across northeastern Surry County, two newly delineated faults, along with extension of the previously delineated fault, define another horst flanked to the south by a narrow graben. This structure coincides with a large meander and peninsula of the James River.

These fault-bounded structures possibly control alignment of river meanders and confluences. The three previously delineated faults extend upward from the Potomac aquifer and are theorized to be rooted in basement bedrock (McFarland and Bruce, 2006). Faults that were newly delineated for this study possibly are also rooted in bedrock. In addition, the combined array of faults is aligned radially from the Chesapeake Bay impact crater and possibly reflects an outer disruption zone that has been theorized to make up part of a broad regional impact structure (Powars and Bruce, 1999; Powars, 2000). The extent and configuration of such a disruption zone is not known in detail, but possibly consists of a radial network of horsts and grabens. Because of sparse borehole data, the structures delineated for this study probably only partially represent the disruption zone, which potentially is considerably larger and more complex. If movement along disruptionzone faults has persisted from the impact event to the present, the faults likely extend to land surface and possibly have influenced topography and drainage.

The faults probably have hydraulic effects on the Piney Point aquifer. Sediment intergranular structure possibly is disrupted by movement to result in locally poor sorting, compaction, and a decrease in hydraulic conductivity along fault planes. Additionally, within the indurated limestone of the Piney Point Formation, faulting may have created discrete fractures that are either open and enhance groundwater flow or lined with fault gouge to impede flow. Faults also create local-scale irregularities in the lateral continuity of the limestone. The Piney Point Formation is partially to completely dislocated vertically along faults (plate 2 , sections $B-B^{\prime}$ and $C-C^{\prime}$ ). Lateral flow constrictions or barriers result where the limestone abuts, and is truncated by, adjacent geologic units. Such constrictions or barriers have been observed to affect groundwater flow as no-flow boundaries (see section "AquiferComponent Test"). 


\section{Impact-Crater Resurge Channel}

A resurge channel associated with the Chesapeake Bay impact crater is interpreted, on the basis of borehole geophysical logs and associated stratigraphic correlation and structure-contour mapping, to underlie the lower Rappahannock River. Some of the geologic units that compose the Piney Point aquifer are truncated by the resurge channel (see section "Geologic Units").

In borehole 59K 36 in Lancaster County (plate 1), only the Calvert Formation, Newport News unit and basal Plum Point Member, Old Church Formation, and Oligocene-age sediments that form the upper to intermediate parts of the Piney Point aquifer are present (figs. 11-13; plate 2, section $B-B^{\prime}$ ). These sediments are underlain by clay of the Chickahominy confining unit and poorly sorted sediments of the Exmore matrix confining unit, determined on the basis of drill cuttings and a geophysical log generated by the VA DEQ. Lower parts of the Piney Point aquifer, including the Gosport Formation equivalent sediments, Piney Point Formation, and the Nanjemoy Formation Woodstock Member, are absent in borehole 59K 36 along with the Nanjemoy Formation Potapaco Member that underlies and forms the base of the aquifer (figs. 6-8, and 10; plate 2, section $B-B^{\prime}$ ). Similarly, on the basis of interpretation of geophysical logs of boreholes 59J 5 and 59J 13 in Middlesex County (plate 1), only the upper to intermediate parts of the Piney Point aquifer are present, and the lower parts are replaced by the Chickahominy confining unit. By contrast, geophysical logs of other nearby boreholes in Gloucester and Middlesex Counties indicate that most or all of the geologic units that compose the Piney Point aquifer are present, and that the Chickahominy and Exmore matrix confining units are absent.

Sediments of the Exmore matrix and Chickahominy confining units fill the Chesapeake Bay impact crater (fig. 2; fig. 3, left side) and have been previously described in detail (McFarland and Bruce, 2006). The impact initially created a powerful outward surge of water and disrupted sediment during excavation of the 50-mi-wide crater cavity (Powars and Bruce, 1999). Subsequently, the surrounding region was subjected to a violent inward resurge of water and excavated sediment that partly filled the crater cavity with the Exmore matrix confining unit. Remnants of the resurge are theorized to still be present outside the crater cavity across an outer disruption zone (see section "Faults"). Clay of the Chickahominy confining unit was then slowly deposited within the remaining unfilled part of the crater cavity during subsequent millennia.

Sediments of the Exmore matrix and Chickahominy confining units intercepted by boreholes $59 \mathrm{~K} 36,59 \mathrm{~J} 5$, and 59J 13 are outside the crater cavity but possibly fill a resurge channel associated with the impact crater. The nearby northwestern boundary of the crater cavity exhibits an outward protrusion (plate 1) that coincides with a complex network of horsts and grabens collectively termed the Rappahannock Canyon (Poag and others, 2004). Compression ridges in basement bedrock and numerous faults within the Exmore matrix and Chickahominy confining units and older sediments were interpreted from seismic surveys near the mouth of the present-day Rappahannock River. The Rappahannock Canyon possibly focused the resurge of water and disrupted sediment into the crater cavity and was subsequently covered by clay of the Chickahominy confining unit.

Accordingly, for this study, a resurge channel was interpreted to extend from the crater cavity upstream beneath the present-day Rappahannock River (figs. 6-8, and 10; plate 2, section $B-B^{\prime}$ ). Sediments of the Exmore matrix and Chickahominy confining units are preserved within the resurge channel outside the crater cavity. Conversely, the Gosport Formation equivalent sediments, Piney Point Formation, Nanjemoy Formation Woodstock Member, and Nanjemoy Formation Potapaco Member originally present outside the crater cavity were scoured away by resurge along the channel. These sediments remain preserved, however, at relatively short distances outside the channel.

The extent and configuration of the resurge channel cannot be known in detail without additional information from boreholes and (or) seismic surveys. Channel width is constrained by nearby boreholes in which the Chickahominy and Exmore matrix confining units are absent, but the width is only approximated for this study as being the same as the present-day Rappahannock River. The channel extends upstream at least as far as borehole 59K 36 and possibly farther. Depth of the resurge channel also is unknown, although horsts and grabens making up the Rappahannock Canyon are interpreted as being seated in basement bedrock (Poag and others, 2004). Relatedly, the boundaries and internal structure of the resurge channel likely consists of complex arrays of faults but are unknown. Whether the alignment of the present-day Rappahannock River may have been influenced by the resurge channel is also unknown. 


\section{Hydrologic Conditions of the Piney Point Aquifer in Virginia}

Spatial and temporal trends in withdrawal from the Piney Point aquifer are summarized. Regional water-level trends, a cone of depression, and interactions among water levels on the York-James peninsula are also described. Transmissivity, storativity, and horizontal hydraulic conductivity of the Piney Point aquifer are estimated using a series of aquifer tests. The hydrochemical composition of the Piney Point aquifer is summarized and analyzed to examine limestone solution channeling and distributions of the concentrations of iron and chloride. Lastly, considerations are offered regarding various aspects of managing the Piney Point aquifer as a water resource.

\section{Groundwater Withdrawals}

Withdrawals from the Piney Point aquifer were summarized for this study during 2015. Groundwater-withdrawal data for all aquifers within the entire Virginia Coastal Plain for the period 1900-2009 were obtained from a study by the USGS of the North Atlantic Coastal Plain (Masterson and others, 2016), which encompasses Atlantic coast states from New York southward into North Carolina. Groundwater-withdrawal data are composed of separately determined rates of regulated reported withdrawals and unregulated unreported withdrawals.

Groundwater users in Virginia withdrawing 300,000 gallons or more during any month are required by law to report withdrawal rates to the VA DEQ (Code of Virginia, Title 62.1, Chapter 25). Reported withdrawals summarized here for 1980-2009 consist of yearly mean daily rates for industrial, municipal, and commercial uses. For the period prior to 1980, reported withdrawals are based on rates previously compiled for a Regional Aquifer System Analysis (RASA) study of the Virginia Coastal Plain conducted by the USGS (Harsh and Laczniak, 1990). Withdrawal rates for recent periods are considered more accurate than those for earlier periods. In addition, an unknown number of withdrawals are suspected of being subject to regulatory requirements but are not reported.

Groundwater users in Virginia withdrawing less than 300,000 gallons during any month are not required to report withdrawal rates. Unregulated withdrawals are generally for individual domestic use. Domestic withdrawals summarized for this study were broadly estimated on a decadal basis from U.S. Census population data and USGS water-use reports (Masterson and others, 2016). The distribution of withdrawals among individual aquifers within the Virginia Coastal Plain was determined using a previously documented method (Pope and others, 2008). Similar to reported withdrawals, the rates of domestic withdrawals are most uncertain for early periods. More specifically, early domestic withdrawals likely are underestimated because a greater proportion of the population relied on individual water sources during the 20th century.

\section{Temporal Trends}

During 1900-2009, withdrawals increased from all aquifers in the Virginia Coastal Plain and from the Piney Point aquifer individually. The total of withdrawals from all aquifers (fig. 14A) was approximately $20 \mathrm{Mgal} / \mathrm{d}$ during 1900; withdrawals were mostly from domestic wells. Total withdrawals peaked during 2002 at $146 \mathrm{Mgal} / \mathrm{d}$, then decreased to $133 \mathrm{Mgal} / \mathrm{d}$ in 2009 (table 1) as a result of a reduction in reported withdrawals from $107 \mathrm{Mgal} / \mathrm{d}$ to $94.2 \mathrm{Mgal} / \mathrm{d}$.

For the Piney Point aquifer (fig. 14B), approximately $1 \mathrm{Mgal} / \mathrm{d}$ was withdrawn during 1900; withdrawals were almost entirely from domestic wells. Withdrawals from the Piney Point aquifer peaked during 2004 at $7.35 \mathrm{Mgal} / \mathrm{d}$, most of which was reported (table 1). Withdrawals then decreased to $5.01 \mathrm{Mgal} / \mathrm{d}$ in 2009 as a result of a reduction in reported withdrawals from $4.97 \mathrm{Mgal} / \mathrm{d}$ to $2.63 \mathrm{Mgal} / \mathrm{d}$; the 2009 reported withdrawal value is similar to that of the domestic withdrawals, $2.38 \mathrm{Mgal} / \mathrm{d}$.

In addition to reported and domestic withdrawal, relatively small rates of withdrawal for agricultural irrigation during 1980-2009 were broadly estimated for the USGS North Atlantic Coastal Plain study (Masterson and others, 2016) on the basis of remote-sensing data and a soil water-balance model. Approximately $14 \mathrm{Mgal} / \mathrm{d}$ for agricultural irrigation was estimated for all aquifers in the Virginia Coastal Plain, and only $0.3 \mathrm{Mgal} / \mathrm{d}$ was estimated for the Piney Point aquifer. Actual irrigation withdrawals from the Piney Point aquifer, however, are likely to be even less. Estimation of the distribution of agricultural irrigation withdrawals among individual

Table 1. Groundwater-withdrawal rates from all aquifers in the Atlantic Coastal Plain in Virginia during 2002 and 2009, and from the Piney Point aquifer during 2004 and 2009.

\begin{tabular}{|c|c|c|}
\hline Withdrawal type & \multicolumn{2}{|c|}{$\begin{array}{c}\text { Withdrawals } \\
\text { (million gallons per } \\
\text { day) }\end{array}$} \\
\hline \multicolumn{3}{|l|}{ All aquifers } \\
\hline & 2002 & 2009 \\
\hline Total & 146 & 133 \\
\hline Domestic & 38.5 & 38.5 \\
\hline Reported & 107 & 94.2 \\
\hline \multicolumn{3}{|c|}{ Piney Point aquifer } \\
\hline & 2004 & 2009 \\
\hline Total & 7.35 & 5.01 \\
\hline Domestic & 2.38 & 2.38 \\
\hline Reported & 4.97 & 2.63 \\
\hline York-James Peninsula & 3.09 & 1.16 \\
\hline West Point & 1.77 & 1.34 \\
\hline Northern Neck and Middle Peninsula & 0.11 & 0.13 \\
\hline
\end{tabular}




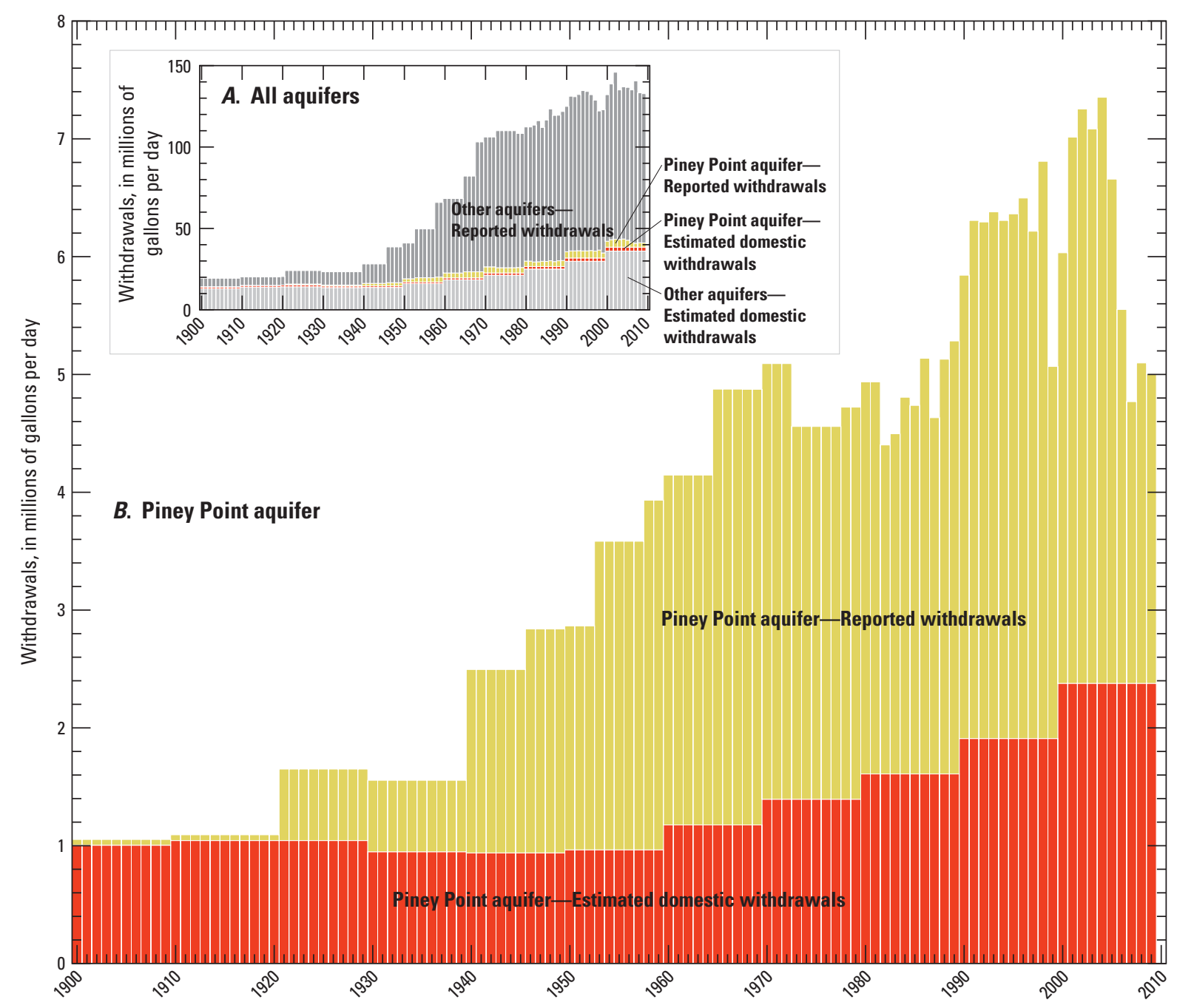

Figure 14. Reported and estimated domestic groundwater withdrawals during 1900-2009 from $A$, all aquifers in the Virginia Coastal Plain and $B$, the Piney Point aquifer.

aquifers was based on the distribution of reported withdrawals among the aquifers. As a result, withdrawals for agricultural irrigation from the surficial aquifer are probably underestimated because there are few reported withdrawals in the surficial aquifer. Likewise, withdrawals for agricultural irrigation from the Piney Point aquifer and other confined aquifers are probably overestimated because most reported withdrawals are for these aquifers.

\section{Spatial Distribution of Reported Withdrawals}

Additional information on individual withdrawal locations is unique to reported withdrawals. Accordingly, locations and rates of reported withdrawals from the Piney Point aquifer were differentiated among (1) the York-James Peninsula, (2) the town of West Point, and (3) the Northern Neck and Middle
Peninsula (fig. 15; table 1). Withdrawal locations and rates are further distinguished between the peak year 2004 (fig. 15A, table 1 center column) and the most recent year of data 2009 (fig. $15 B$, table 1 right column).

The largest reported withdrawals from the Piney Point aquifer are geographically concentrated on the York-James Peninsula and are mostly for municipal use to supply a large public drinking-water system. As a result, the York-James Peninsula has developed a water-level cone of depression in the Piney Point aquifer estimated at times to be deeper than $80 \mathrm{ft}$ below sea level (Heywood and Pope, 2009) (see section "Groundwater Levels"). Between 2004 and 2009, however, locations of withdrawals from the Piney Point aquifer on the York-James Peninsula became fewer (fig. 15), and the withdrawal rate decreased from $3.09 \mathrm{Mgal} / \mathrm{d}$ to $1.16 \mathrm{Mgal} / \mathrm{d}$ (table 1). During this period, reported municipal withdrawals 

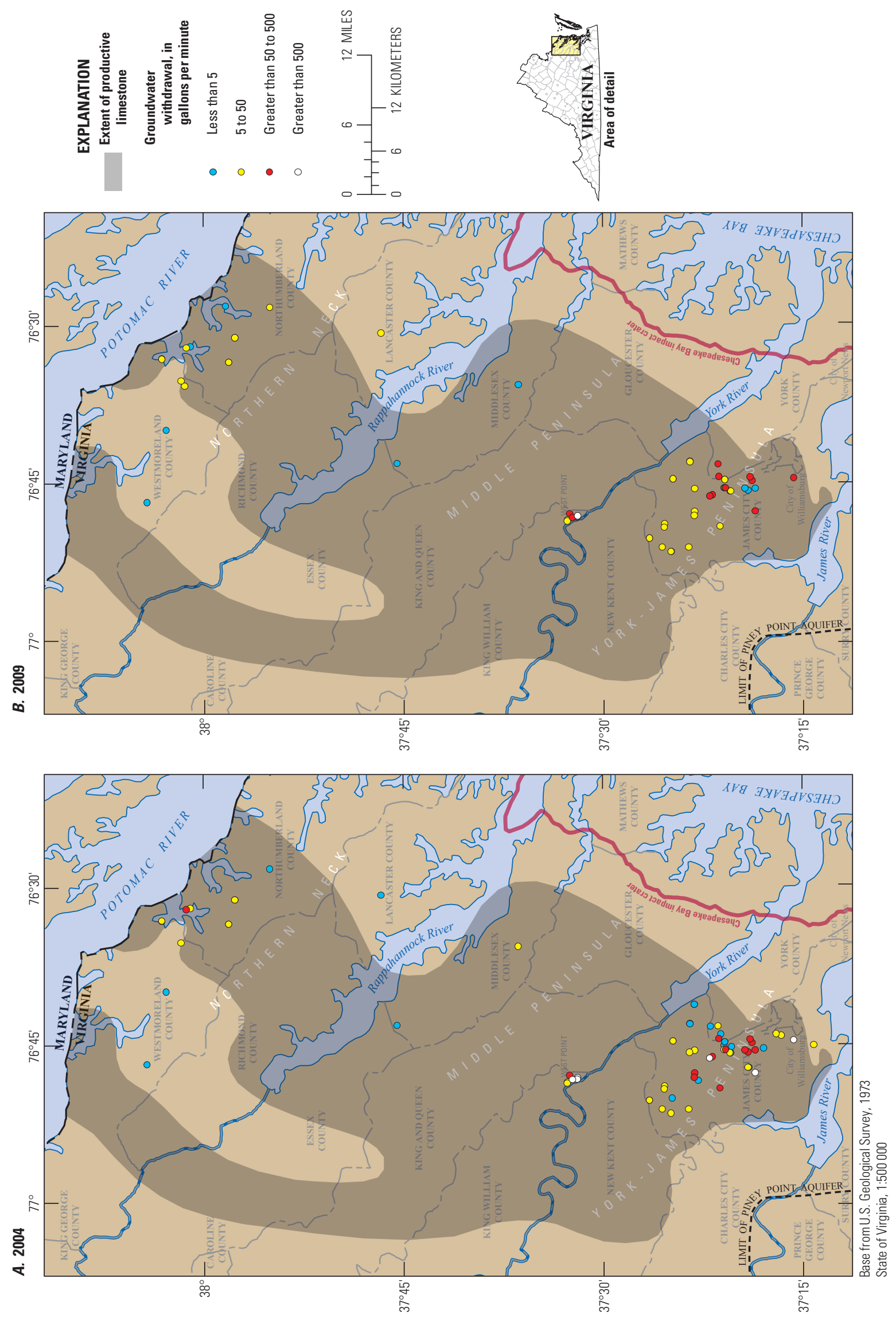

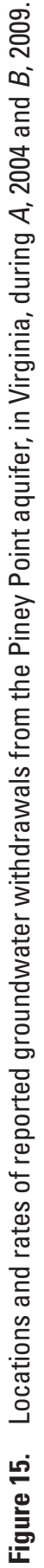


shifted from the Piney Point aquifer to withdrawals and treatment of deeper brackish groundwater from the Potomac aquifer.

In addition to the York-James Peninsula, reported withdrawals at the town of West Point for mostly industrial use also decreased between 2004 and 2009 from $1.77 \mathrm{Mgal} / \mathrm{d}$ to $1.34 \mathrm{Mgal} / \mathrm{d}$ (table 1). Other withdrawal data compiled for a separate study (McFarland, 2015) indicate further decreases by 2013 on the York-James Peninsula to $0.99 \mathrm{Mgal} / \mathrm{d}$ and at West Point to $0.76 \mathrm{Mgal} / \mathrm{d}$. By contrast, the number of withdrawal locations on the Northern Neck and Middle Peninsula increased slightly between 2004 and 2009 (fig. 15) as the withdrawal rate increased from $0.11 \mathrm{Mgal} / \mathrm{d}$ to $0.13 \mathrm{Mgal} / \mathrm{d}$ (table 1). This increase is mostly due to increasing demands for municipal use that supplies small but expanding community drinking-water systems.

In summary, both reported and domestic withdrawals from the Piney Point aquifer increased from 1900 to 2004, but by 2009 , reported withdrawals had decreased (fig. 14, table 1 ). A geographic shift in reported withdrawals, however, along with anticipated future increases in domestic withdrawals, indicates that the spatial distribution of withdrawals from the Piney Point aquifer is gradually broadening.

\section{Groundwater Levels}

Withdrawals from the Piney Point aquifer have resulted in water-level declines (see sections "Introduction" and "Groundwater Withdrawal"). Accordingly, trends in water levels in the Piney Point aquifer were analyzed at various spatial and temporal scales within the study area. Although the Piney Point aquifer subcrops along major river valleys that cross its westernmost margin, the aquifer is entirely confined within the designated study area surrounding the productive limestone in which withdrawals from the aquifer are made.

\section{Regional Water-Level Trends}

Long term trends in water levels in the Piney Point aquifer were evaluated during 2015. Historical water-level measurements in the Piney Point aquifer were compiled from the USGS NWIS database for Virginia. A previously documented method (McFarland, 2010) used well-construction data and the regional hydrogeologic framework (McFarland and Bruce, 2006) to identify 19 observation wells (1) that are open to Piney Point aquifer and (2) from which two or more water levels were measured 1 year or more apart. Yearly mean water levels calculated from individual water-level measurements in each well span the period from 1906 to 2015 (fig. 16).

Most of the observation wells are located in James City County (fig. 16B) where the largest withdrawal from the Piney Point aquifer is made, mostly for municipal use to supply a large public drinking-water system (see section "Groundwater Withdrawal"). Most of the water levels in these wells were measured during 1960-1995 (fig. 16A). Water levels continu- ously declined during this period from close to or above sea level to as deep as nearly -60 ft. Water levels in well 56H 29 measured after 1995 declined further until 2005, followed by partial recovery of approximately $14 \mathrm{ft}$ by 2015 . Water levels recovered as municipal withdrawals were shifted from the Piney Point aquifer to deeper brackish groundwater from the Potomac aquifer, which was then treated (see section "Groundwater Withdrawal").

Only five of the observation wells are located outside of the area of large withdrawals in James City County (fig. 16B). Water levels in these wells remained close to or above sea level, including levels in three of the wells measured as recently as 2015 (fig. 16A). Hence, water levels in the Piney Point aquifer generally declined less outside of James City County than inside.

\section{Water-Level Cone of Depression}

A model simulation of the entire Virginia Coastal Plain aquifer system (Heywood and Pope, 2009) estimated that withdrawal from the Piney Point aquifer had by 2003 resulted in a water-level cone of depression as low as $-80 \mathrm{ft}$ in James City and northern York Counties. The distribution of actual water levels, however, was not determined accurately enough to evaluate this simulation result. Water levels had been measured at an inadequate number of locations and with varying frequency.

Accordingly, an analysis was undertaken during 2009 to more accurately delineate the cone of depression in the Piney Point aquifer in James City and northern York Counties. Because of the paucity of observation-well data, water-level measurements from 10 active production wells in James City County (fig. 17D) were obtained from the James City Service Authority (JCSA) for the period from September 1, 2008, to August 31, 2009. All of the production wells are open to the part of the Piney Point aquifer composed of limestone in the Piney Point Formation (see section "Piney Point Formation"). The water levels were measured as part of JCSA's Supervisory Control and Data Acquisition (SCADA) system used to operate water production and distribution. Water levels in all of these active production wells exhibited short-term fluctuations of multiple tens of feet resulting from pump cycling. The wells were not pumped continuously and, upon cessation of pumping, water levels rapidly recovered to a stable baseline. Graphical analysis identified approximate seasonal low static water levels in each production well during September 2008 (fig. 17A) and August 2009 (fig. 17C), and a seasonal high static water level during May 2009 (fig. 17B).

The approximate seasonal static water levels in production wells were augmented with water levels in the only two nearby observations wells that were measured during the period (fig. 17D). Observation well 56H 29 is in James City County and is open to the limestone in the Piney Point Formation. Observation well 58F 53 is to the southeast in the City of Newport News approximately $8 \mathrm{mi}$ beyond the extent of the limestone; well 58F 53 is open to the part of the Piney 


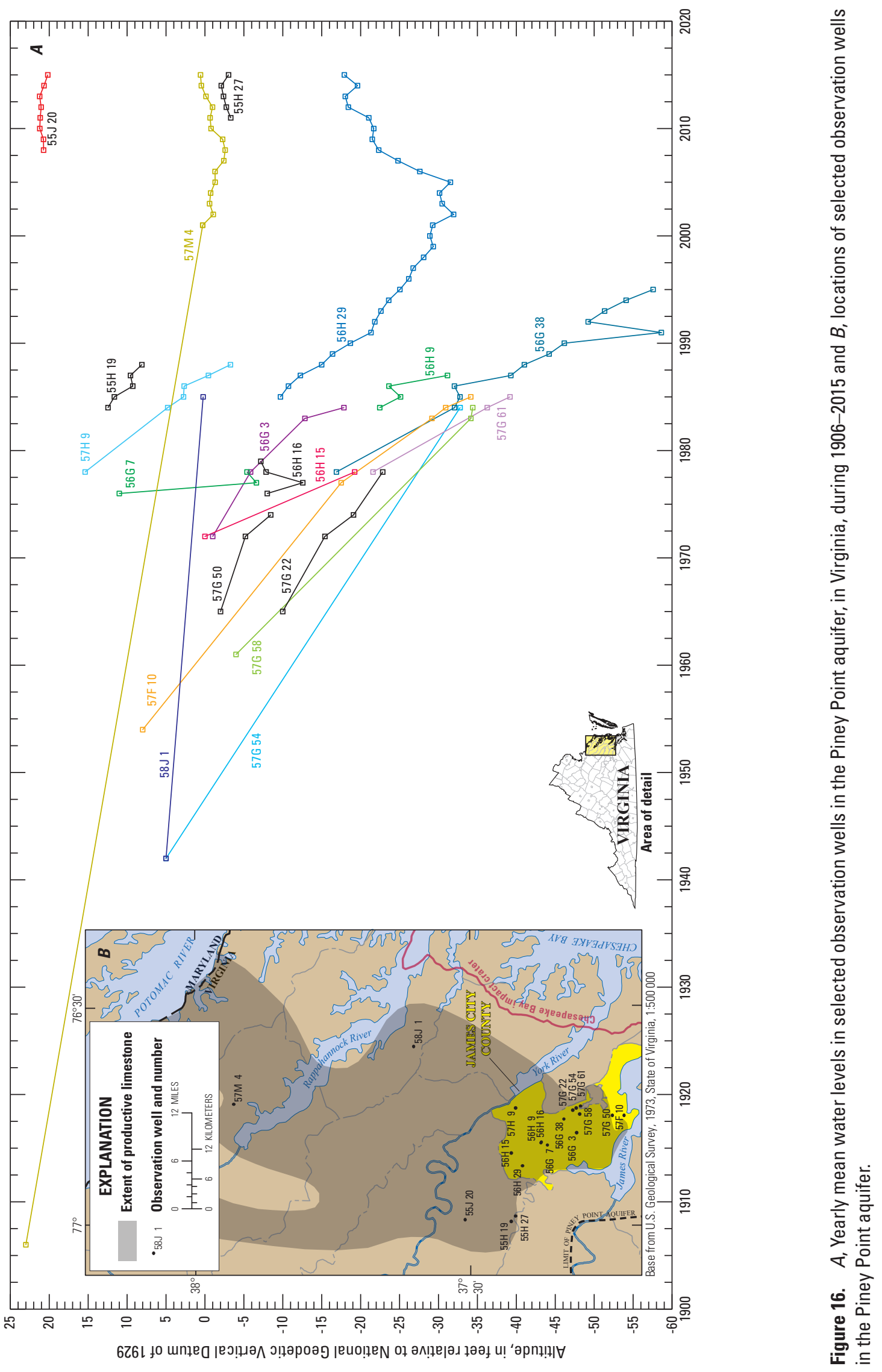



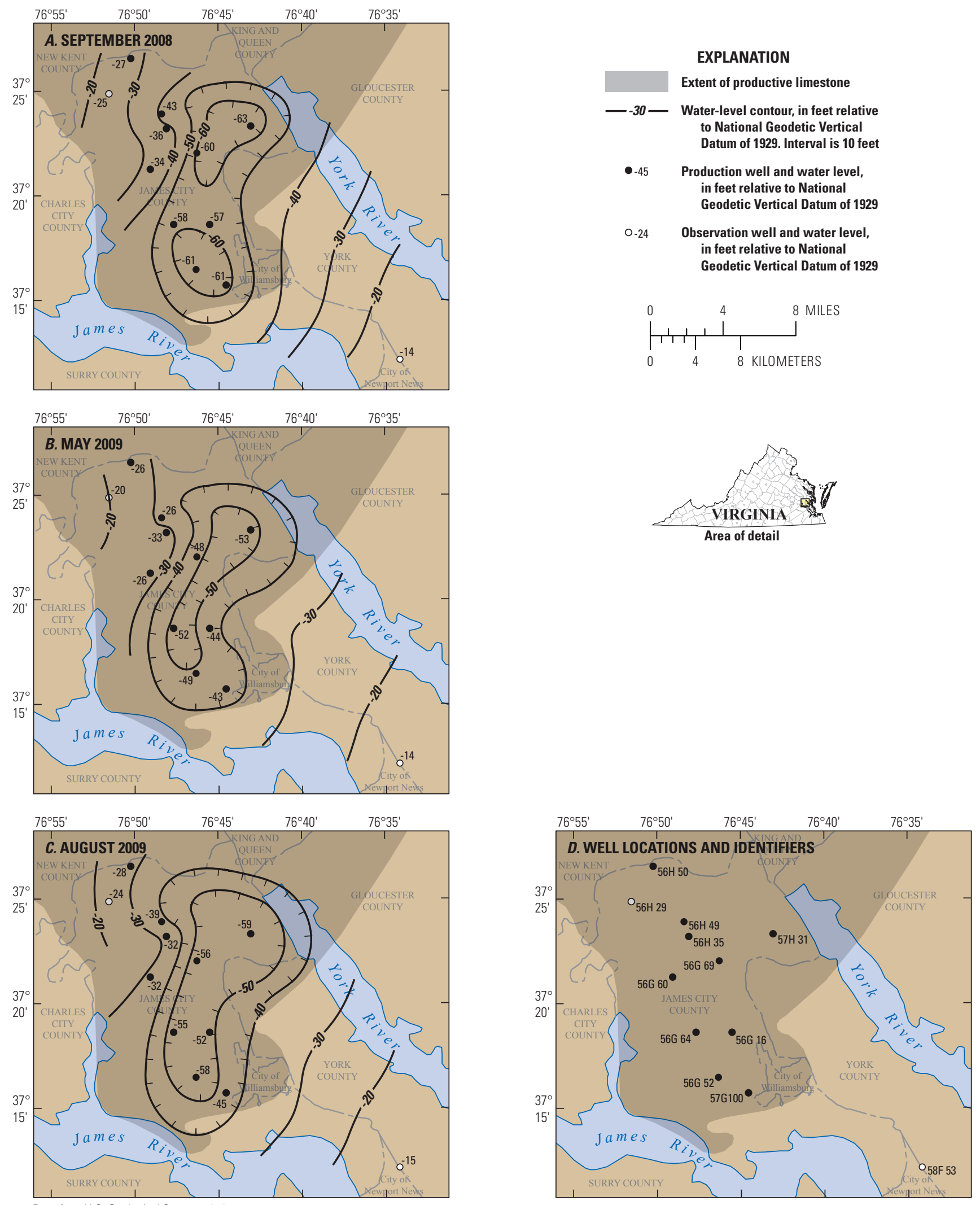

Base from U.S. Geological Survey, 1973

State of Virginia, 1:500 000

Figure 17. Estimated water levels in the Piney Point aquifer during $A$, September 2008, $B$, May 2009, and $C$, August 2009, and $D$, production- and observation-well locations. 
Point aquifer composed of silty sand in the Calvert Formation, Newport News unit and basal Plum Point Member (see section "Calvert Formation, Newport News unit and basal Plum Point Member").

Contour maps constructed from the approximate seasonal static water levels confirm the presence of a cone of depression in the Piney Point aquifer in James City and northern York Counties during 2008-09 (fig. 17A-C). The cone of depression had an oblong bi-lobate shape that was oriented with its long axis from northeastern James City County southward to the western part of the City of Williamsburg. Production well 57H 31 consistently had the lowest water levels. The lowest approximate seasonal static water level was -63 ft during September 2008. Likewise, the cone of depression was lowest at that time, based on water levels in the other wells. The water level in well 57H 31 recovered by $10 \mathrm{ft}$ to $-53 \mathrm{ft}$ by May 2009 when the cone of depression also partly recovered. The water level in well $57 \mathrm{H} 31$ then declined by $6 \mathrm{ft}$ to $-59 \mathrm{ft}$ by August 2009 as the cone of depression also declined. Fluctuation in the cone of depression resulted from a seasonal demand that usually occurs for the public drinkingwater system. The lowest part of, and the largest fluctuations in, the cone of depression during 2008-09 were at its center. By contrast, water levels on the higher flanks of the cone of depression to the northwest and southeast were relatively stable within a range of only 1 or $2 \mathrm{ft}$.

Water levels were measured in observation well 56H 29 from 1985 through 2015 (fig. 16A). The yearly mean water level in well 56H 29 declined steadily to its lowest point of approximately $-30 \mathrm{ft}$ during 2003-05, which is $5 \mathrm{ft}$ to $10 \mathrm{ft}$ lower than its approximate seasonal static water levels during 2008-09 (fig. 17A-C). On the basis of relations between water levels in observation well $56 \mathrm{H} 29$ and in the production wells during 2008-09, the center of the cone of depression in 2003-05 was possibly as low as $-70 \mathrm{ft}$. The yearly mean water level in well $56 \mathrm{H} 29$ recovered to approximately $-16 \mathrm{ft}$ by 2015 (fig. 16A). The center of the cone of depression probably also recovered by 2015 to approximately $-50 \mathrm{ft}$. Water levels have recovered since 2005 because municipal withdrawals were shifted from the Piney Point aquifer to deeper brackish groundwater from the Potomac aquifer, which was then treated (see section "Groundwater Withdrawal").

\section{Water-Level Interactions on the York-James Peninsula}

Interactions among water levels in the Piney Point aquifer on the York-James Peninsula during March-September 2015 were examined. Continuous water-level measurements were compiled from the USGS NWIS database for Virginia for observation wells cooperatively maintained by USGS and the VA DEQ in northern York County, southern New Kent County, and northern City of Newport News (fig. 18).

Observation wells include collocated wells 57G129 and 57 G130 in northern York County (fig. 18E) that were con- structed by the VA DEQ in early 2015 as part of a groundwater research station (see section "Aquifer-Component Test"). The research station is within the area of large groundwater withdrawals and the associated water-level cone of depression in James City and northern York Counties (see section "Water-Level Cone of Depression"). Well 57 G129 is open to the part of the Piney Point aquifer composed of limestone in the Piney Point Formation (see section "Piney Point Formation"). Well 57G130 is open to the overlying part of the Piney Point aquifer composed of silty sand of the Calvert Formation, Newport News unit and basal Plum Point Member (see section "Calvert Formation, Newport News Unit and Basal Plum Point Member"). Continuous water-level measurement in both wells began on March 3, 2015 (fig. 18A).

Water levels at the groundwater research station were augmented with water levels in the only two nearby observations wells that were continuously measured during the period (figs. $18 B$ and $C$ ). Both of these observation wells are outside the area of large groundwater withdrawals and the associated cone of depression (fig. 18E). Well 55H 27 is in southern New Kent County approximately $15 \mathrm{mi}$ west of the research station and is open to the limestone in the Piney Point Formation. Well 58F 53 is sited beyond the extent of the limestone in the northern part of the City of Newport News approximately $13 \mathrm{mi}$ southeast of the research station and is open to silty sand in the Calvert Formation, Newport News unit and basal Plum Point Member.

\section{Seasonal Water Demand}

Water levels in observation wells 57G129 and 57G130 at the groundwater research station were affected during much of March 2015 by aquifer testing, which is discussed later in this report (see section "Aquifer-Component Test"). Throughout most of March-September 2015, water levels in the two wells remained within several hundredths of a foot of each other and fluctuated daily by several tenths of feet (fig. 18A). Both wells also exhibited a seasonal trend during the period not affected by aquifer testing. Water levels recovered from approximately $-44 \mathrm{ft}$ in early March to $-42 \mathrm{ft}$ by May, then declined to approximately $-46.5 \mathrm{ft}$ by September for a total decline of approximately $4.5 \mathrm{ft}$. Partial water-level recoveries of approximately $1 \mathrm{ft}$, however, also took place at four times during the period.

Water levels in observation wells 55H 27 and 58F 53 during March-September 2015 (fig. 18B and C) differed in several respects from those in wells $57 \mathrm{G} 129$ and $57 \mathrm{G} 130$ at the groundwater research station. Water levels in well 55H 27 were approximately $41 \mathrm{ft}$ higher, and in well 58F 53 approximately $27 \mathrm{ft}$ higher, than at the research station. Daily waterlevel fluctuations in well 55H 27 were only approximately $0.1 \mathrm{ft}$ and were timed differently from water levels at the research station. Water levels in well 58F 53 fluctuated even less, by only a few hundredths of a foot over periods as long as a day or more. Water levels in wells 55H 27 and 58F 53 exhibited a seasonal trend that roughly coincided with the 

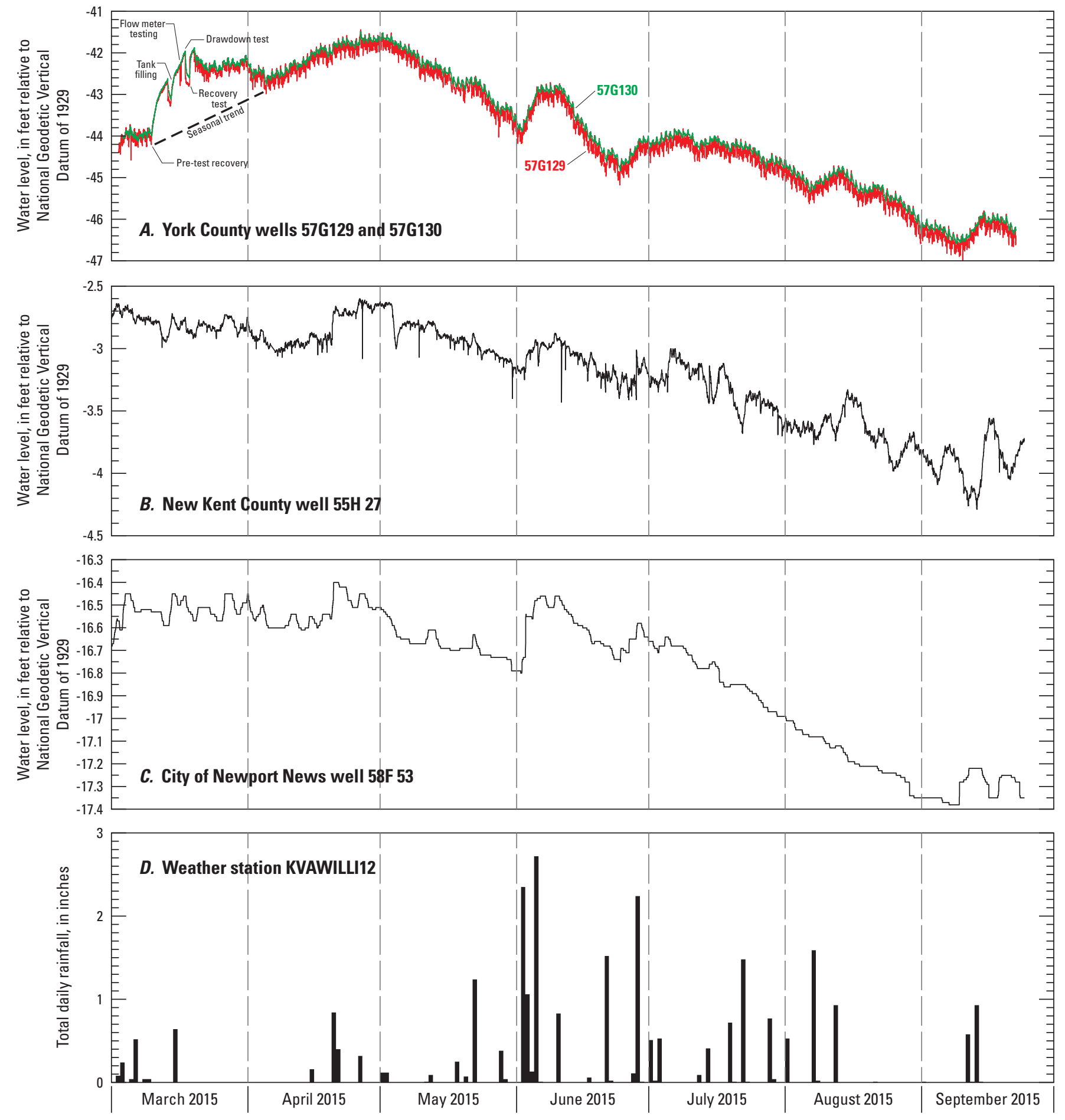

Figure 18. Water levels in continuously measured observation wells $A, 57 \mathrm{G} 129$ and $57 \mathrm{G} 130$ in York County, $B, 55 \mathrm{H} 27$ in New Kent County, and $C, 58 \mathrm{~F} 53$ in the City of Newport News, Virginia, during March-September 2015, $D$, total daily rainfall downloaded from Weather Underground weather station KVAWILLI12 on September 23, 2015, and E, locations of observation wells, selected production wells, weather station, and faults. 


\section{E. Weather station KVAWILLI12}

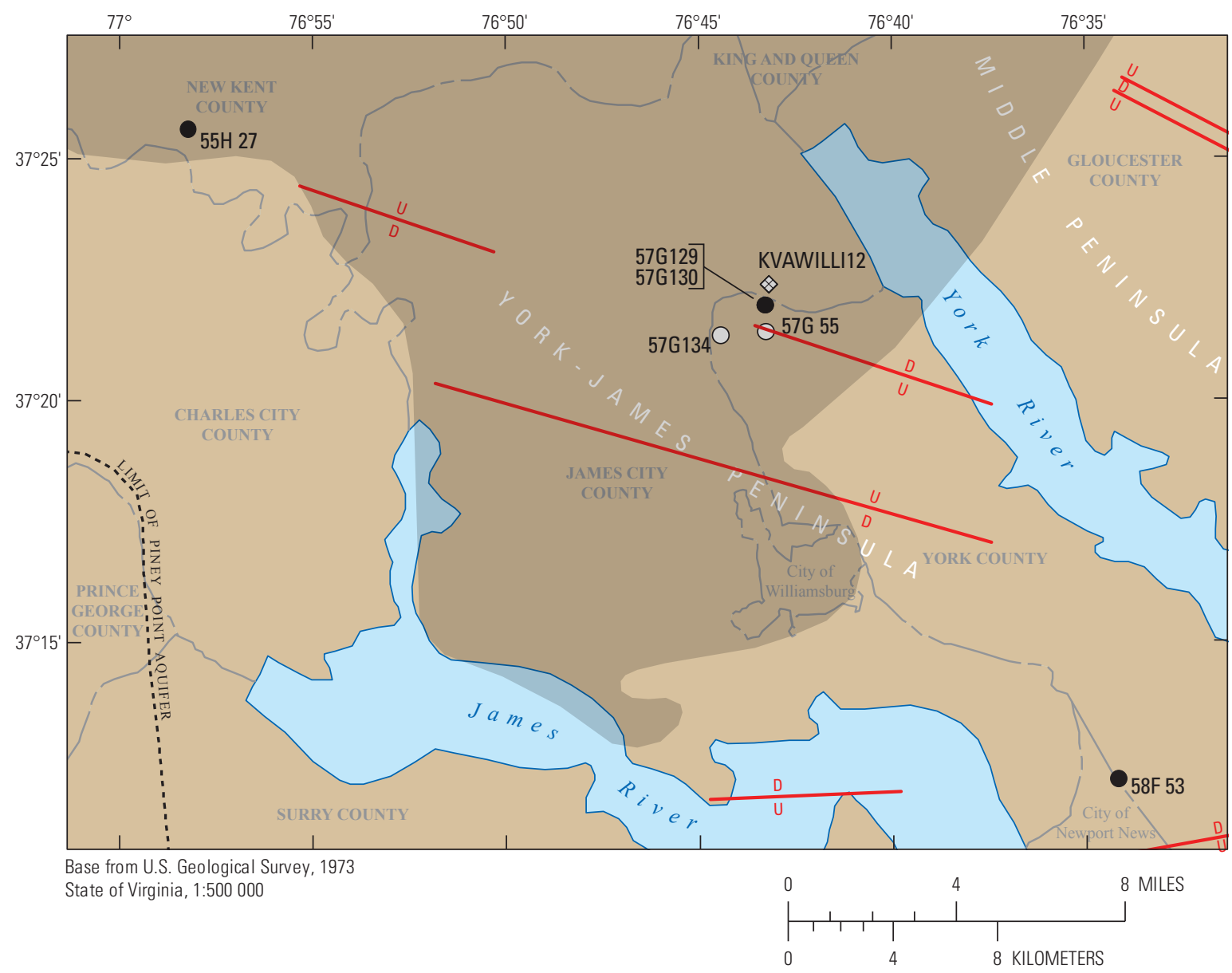

EXPLANATION

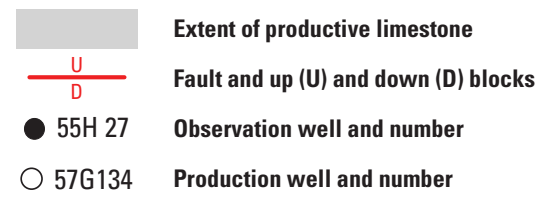

$\Leftrightarrow$ KVAWILLI12 Weather station and number

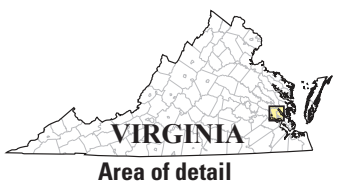

Figure 18. Water levels in continuously measured observation wells $A, 57 \mathrm{G} 129$ and $57 \mathrm{G} 130$ in York County, $B, 55 \mathrm{H} 27$ in New Kent County, and $C, 58 \mathrm{~F} 53$ in the City of Newport News, Virginia, during March-September 2015, $D$, total daily rainfall downloaded from Weather Underground weather station KVAWILLI12 on September 23, 2015, and $E$, locations of observation wells, selected production wells, weather station, and faults.-Continued 
research station but with a smaller overall decline of approximately $1 \mathrm{ft}$ to $1.5 \mathrm{ft}$. Partial water-level recoveries in wells $55 \mathrm{H} 27$ and 58F 53 took place 3 or 4 times during the period of overall decline, which is similar to the timing of recoveries and declines at the research station, but only of a few tenths of a foot.

The seasonal water-level trend during March-September 2015 indicates a continuation of the fluctuation in the cone of depression observed during 2008-09 that resulted from seasonal demand that usually occurs for the public drinkingwater system (see section "Water-Level Cone of Depression"). Relatively low water levels, and large water-level daily fluctuations and seasonal declines, in observation wells 57G129 and 57G130 at the groundwater research station (fig. 18A) reflect the locations of the wells toward the center of the cone of depression. Conversely, water levels in wells 55H 27 and $58 \mathrm{~F} 53$ sited outside of the cone of depression were higher and relatively stable (fig. $18 B$ and $C$ ).

\section{Water-Table Recharge}

Water levels in all four observation wells partially recovered at approximately the same times during the period of overall decline (fig. $18 A-C$ ). The water-level recoveries coincided with local rainfall events in early June, late June into early July, early August, and early September. Groundwater levels were augmented with daily rainfall totals during March-September 2015 (fig. 18D) that were downloaded on September 23, 2015, from the Web site wunderground.com for weather station KVAWILLI12 located approximately $0.5 \mathrm{mi}$ north of the groundwater research station (fig. 18E)

The Piney Point aquifer receives direct recharge only under unconfined conditions across its westernmost margin where it subcrops along major river valleys. The nearest subcrop area has been mapped between approximately $3 \mathrm{mi}$ to $30 \mathrm{mi}$ west of the observation wells (McFarland and Bruce, 2006). Conversely, the Piney Point aquifer is confined at the observation wells, where the altitude of the top surface is $-59 \mathrm{ft}$ at well $55 \mathrm{H} 27,-145 \mathrm{ft}$ at wells $57 \mathrm{G} 129$ and $57 \mathrm{G} 130$, and $-269 \mathrm{ft}$ at well $58 \mathrm{~F} 53$.

On the basis of confinement of the Piney Point aquifer at the observation wells, partial water-level recoveries in the observation wells during the period of overall decline did not result from direct recharge to the Piney Point aquifer during the rainfall events. Instead, water levels in the Piney Point aquifer rose in response to an increase in hydrostatic pressure produced by recharge at the water table, which is positioned in the surficial aquifer within a few tens of feet or less from land surface.

\section{Cyclic Pumping}

Other than the period that was affected by aquifer testing (see section "Aquifer-Component Test"), water levels in observation wells 57G129 and 57G130 at the groundwater research station fluctuated regularly during March-September 2015 generally three times daily by several tenths of feet (fig. 19A).
The water levels were affected by pumping from two nearby municipal-supply production wells, including well 57G 55 sited approximately $0.6 \mathrm{mi}$ to the south and well 57G134 approximately $1.3 \mathrm{mi}$ to the southwest (fig. $18 E$ ). Continuously measured withdrawal rates obtained from the City of Newport News Waterworks (R.E. Harris, City of Newport News, written commun., 2015) indicate that pumping was cycled at roughly 4-hour intervals at rates of approximately $200 \mathrm{gal} / \mathrm{min}$ in well $57 \mathrm{G} 55$ and $550 \mathrm{gal} / \mathrm{min}$ in well $57 \mathrm{G} 134$ (fig. $19 C$ and $D$ ). Alternating periods of water-level decline and recovery in the observation wells coincided closely with pumping of the production wells.

Vertical hydraulic gradients between observation wells $57 \mathrm{G} 129$ and $57 \mathrm{G} 130$ were calculated assuming that the water levels represent hydraulic head at the middle of each of the well open intervals. Water-level fluctuations in well 57G129 were approximately twice as large as those in well $57 \mathrm{G} 130$ and preceded those in well 57 G130 by 1-2 hours (fig. 19A). Water levels in 57G129 declined below those in 57G130 during decline and rose above them during recovery. As a result, the vertical hydraulic gradient between the two wells regularly reversed direction between downward (positive values) during pumping and upward (negative values) during recovery (fig. 19B). This relation was maintained throughout MarchSeptember 2015 other than when conditions were affected by aquifer testing.

Production wells 57G 55 and 57G134 are typical of municipal water-supply system wells in that they are operated on a regularly cycled multi-hour basis rather than continuously. Thus, throughout the area of large groundwater withdrawals from the Piney Point aquifer in James City and northern York Counties, vertical hydraulic gradients probably reverse frequently between limestone of the Piney Point Formation and overlying silty sand of the Calvert Formation, Newport News unit and basal Plum Point Member. Alternating periods of pumping among numerous production wells thereby create the potential for a zone of vertical leakage and mixing of water between the two geologic units. As a result, desirable sodium-bicarbonate water in the limestone can be mixed with undesirable water from the silty sand containing elevated concentrations of iron and hydrogen sulfide (see section "Iron").

\section{Hydraulic Properties}

Aquifer tests conducted in the Piney Point aquifer between 1972 and 2011 provide estimates of aquifer transmissivity and storativity. Transmissivity and storativity values, along with measurements of specific capacities for wells open to the Piney Point aquifer, indicate a northward downward trend in transmissivity that probably results from poor development of solution-channeled limestone of the Piney Point Formation.

A specialized aquifer test conducted in York County during 2015 indicated that the transmissivity and horizontal hydraulic conductivity of interbedded limestone and sand of the Piney Point Formation are nearly an order of magnitude 
A. Observation wells $57 \mathrm{G129}$ and $57 \mathrm{G130}$

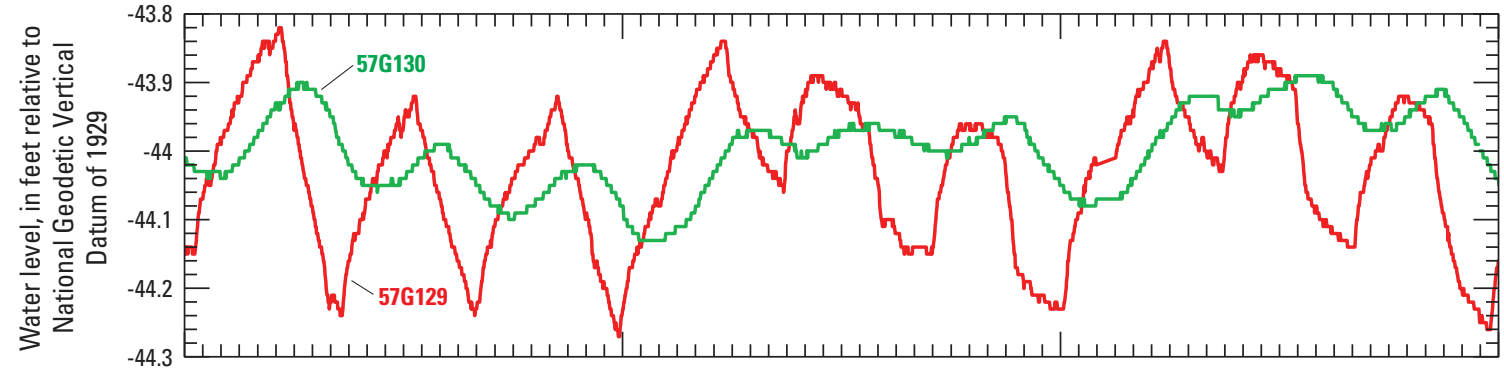

B. Vertical hydraulic gradient between 57 G129 and 57 G130

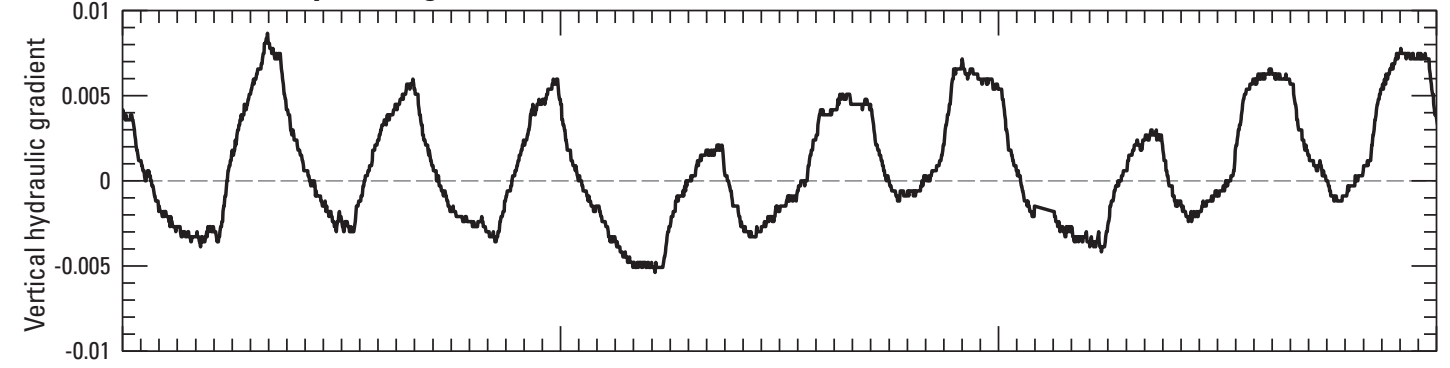

C. Withdrawal rate for $57 \mathrm{G} 55$
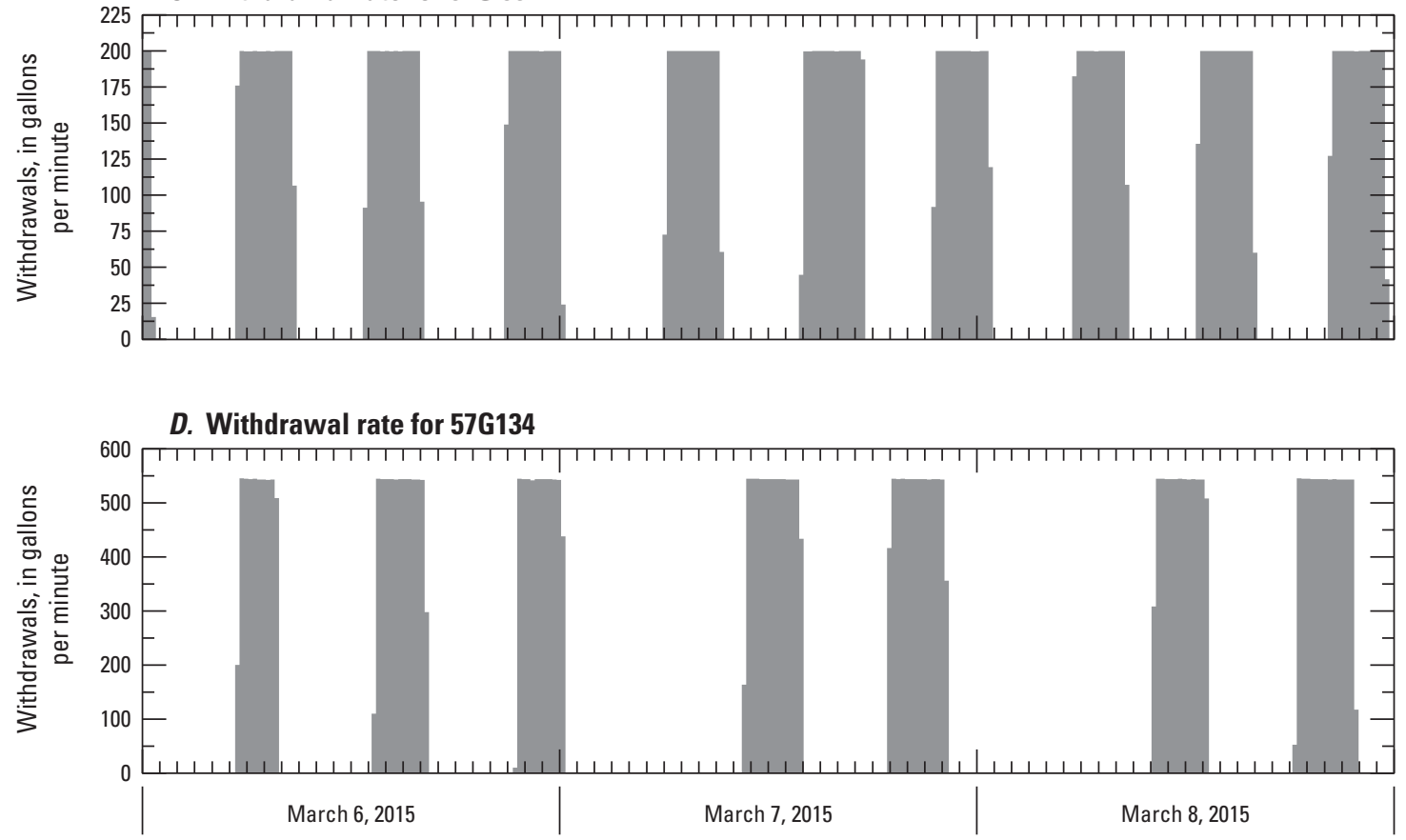

Figure 19. Hydrodynamic intractions in northern York County, Viginia, during March 6-8, 2015: $A$, water levels in observation wells $57 \mathrm{G} 129$ and $57 \mathrm{G} 130, B$, vertical hydraulic gradient between observation wells $57 \mathrm{G} 129$ and $57 \mathrm{G} 130$ (positive values are downward, and negative values are upward), $C$, groundwater-withdrawal rates for production well $57 G 55$, and $D$, groundwater-withdrawal rates for production well $57 G 134$. (Well locations shown in figure 17.) 
greater than that of overlying silty sand of the Calvert Formation, Newport News unit and basal Plum Point Member. In addition, pumping of the limestone and sand induces vertical leakage and water-level decline in the silty sand.

\section{Historical Aquifer Tests}

Results are summarized below for 14 aquifer tests conducted in the Piney Point aquifer in the Virginia Coastal Plain and an adjacent part of Maryland between 1972 and 2011. Estimates of aquifer transmissivity and storativity and allied information (table 2) were compiled during 2015. Information on the aquifer tests was obtained from three sources.

One source of information on aquifer tests in the Piney Point aquifer is groundwater-site data on file at the USGS Virginia Water Science Center. Records of wells open to the Piney Point aquifer contain time-series water-level data collected by drillers during five aquifer tests conducted between 1972 and 2011 (table 2). Four of the aquifer tests were conducted at wells in proximity to large groundwater withdrawals in York and James City Counties (fig. 20A). The location of the fifth aquifer test was conducted to the north in Northumberland County. Only a production well was used in four of the aquifer tests. The fifth test included a production well and two observation wells. For the five aquifer tests, pumping was conducted for either 24 hours or 48 hours at constant rates ranging from $50 \mathrm{gal} / \mathrm{min}$ to $350 \mathrm{gal} / \mathrm{min}$.

The transmissivity of the Piney Point aquifer was estimated using the method of Cooper and Jacob (1946) with USGS groundwater-site records from three aquifer tests containing measurements of water-level drawdown, recovery, and residual drawdown in production wells and observation wells. Estimates of transmissivity from another aquifer test were based only on drawdown in a production well. For the remaining aquifer test, only recovery and residual drawdown in a production well were used. Storativity of the Piney Point aquifer was estimated only from the aquifer test that included observation-well water levels during drawdown and recovery. Complete documentation of these aquifer-test analyses are on file at the USGS Virginia Water Science Center.

Another source of information on aquifer tests in the Piney Point aquifer is a series of four reports obtained from the VA DEQ and published by Russnow-Kane and Associates to document water-supply development of the Piney Point aquifer (Russnow-Kane and Associates, 1996a-c, 2010). Three of these aquifer tests were conducted during 1996 and the fourth during 2009 (table 2). All of the aquifer tests (1) were at wells sited in the area of large groundwater withdrawals in York and James City Counties (fig. 20A), (2) included one production well and one observation well, and (3) conducted pumping for 48 hours at constant rates ranging from $365 \mathrm{gal} / \mathrm{min}$ to $543 \mathrm{gal} / \mathrm{min}$. The transmissivity of the Piney Point aquifer was estimated using all of the aquifer tests with measurements of water-level drawdown and recovery in production wells and observation wells, and the method of Cooper and Jacob (Cooper and Jacob, 1946). Measurements from three of the aquifer tests also included residual drawdown in a production well. Storativity of the Piney Point aquifer was estimated using only one aquifer test with water-level drawdown and recovery in an observation well.

The third source of information on aquifer tests in the Piney Point aquifer is records published by the Maryland Geological Survey (Andreasen and others, 2012). Five aquifer tests at wells open to the Piney Point aquifer in the Maryland Coastal Plain (fig. 20A) were conducted between 1991 and 1998 (table 2). Each of the aquifer tests included only a production well and no observation wells. Pumping was conducted for 11-24 hours at constant rates of $44 \mathrm{gal} / \mathrm{min}$ to $77 \mathrm{gal} / \mathrm{min}$. The transmissivity of the Piney Point aquifer was estimated using the method of Cooper and Jacob (1946). Only water-level drawdowns were used from two aquifer tests, and only recoveries were used for another two aquifer tests. For the remaining aquifer test, both drawdown and recovery were used. Because none of the aquifer tests included observation wells, storativity of the Piney Point aquifer was not estimated.

In total, information on 14 aquifer tests was obtained from three sources. Wells used for nine of the aquifer tests were in proximity to large groundwater withdrawals in York and James City Counties (fig. 20A). These aquifer tests also produced the largest estimates of the transmissivity for the Piney Point aquifer, with a mean of 16,300 feet squared per day $\left(\mathrm{ft}^{2} / \mathrm{d}\right)$. Estimates of transmissivity from these aquifer tests also vary over a large range from $840 \mathrm{ft}^{2} / \mathrm{d}$ to $30,907 \mathrm{ft}^{2} / \mathrm{d}$. Three of these aquifer tests produced estimates of storativity ranging from $8.90 \times 10^{-6}$ to $1.98 \times 10^{-5}$.

The five remaining aquifer tests were conducted at locations farther north, including four in Maryland and one in northwestern Northumberland County, Va. (fig. 20A). These aquifer tests produced most of the small estimates of the transmissivity for the Piney Point aquifer, with a mean of $925 \mathrm{ft}^{2} / \mathrm{d}$. These estimates of transmissivity also vary over a narrower range than those for locations farther south, from $260 \mathrm{ft}^{2} / \mathrm{d}$ to $1,900 \mathrm{ft}^{2} / \mathrm{d}$. None of these aquifer tests produced estimates of storativity.

Generally large estimates of the transmissivity of the Piney Point aquifer in the area of large groundwater withdrawal in York and James City Counties contrast with smaller estimates in northwestern Northumberland County and Maryland. Transmissivity possibly decreases northward through Virginia into Maryland. The thickness of the Piney Point Formation from which most withdrawals are made, however, is relatively constant from south to north (plate 2 , section $C$ - $C^{\prime}$ ). Alternatively, solution-channeled limestone of the Piney Point Formation that dominates the productive part of the Piney Point aquifer to the south possibly is poorly developed to the north (see section "Extent of Limestone"). Southward and northward locations of the aquifer tests, however, are widely separated. No estimates of transmissivity are available for the intervening area that is more than $40 \mathrm{mi}$ wide. 
Table 2. Estimates of transmissivity and storativity of the Piney Point aquifer in Virginia and an adjacent part of Maryland, using aquifer tests, 1972-2011.

[nd, no data]

\begin{tabular}{|c|c|c|c|c|c|c|c|c|c|c|}
\hline $\begin{array}{c}\text { Well } \\
\text { number }\end{array}$ & $\begin{array}{l}\text { Test } \\
\text { year }\end{array}$ & Well type & $\begin{array}{c}\text { Flow rate } \\
\text { (gallons } \\
\text { per } \\
\text { minute) }\end{array}$ & $\begin{array}{c}\text { Duration } \\
\text { (hours) }\end{array}$ & $\begin{array}{c}\text { Distance } \\
\text { (feet) }\end{array}$ & $\begin{array}{l}\text { Transmissivity } \\
\text { drawdown } \\
\text { (feet squared } \\
\text { per day) }\end{array}$ & $\begin{array}{l}\text { Transmissivity } \\
\text { recovery } \\
\text { (feet squared } \\
\text { per day) }\end{array}$ & $\begin{array}{l}\text { Transmissivity } \\
\text { residual } \\
\text { (feet squared } \\
\text { per day) }\end{array}$ & $\begin{array}{l}\text { Storativity } \\
\text { drawdown }\end{array}$ & $\begin{array}{c}\text { Storativity } \\
\text { recovery }\end{array}$ \\
\hline \multicolumn{11}{|c|}{ Groundwater-site data on file at the U.S. Geological Survey Virginia Water Science Center } \\
\hline $56 \mathrm{G} 6$ & 1972 & Production & 132 & 24 & 0 & nd & 2,200 & 7,800 & nd & nd \\
\hline $57 \mathrm{G} 29$ & 1973 & Production & 316 & 24 & 0 & 3,800 & 10,000 & 9,100 & nd & nd \\
\hline $57 \mathrm{G} 55$ & 2011 & Production & 350 & 48 & 0 & 19,000 & 18,000 & 18,000 & nd & nd \\
\hline $57 \mathrm{G} 132$ & 2011 & Observation & 0 & 0 & 71 & 16,000 & 20,000 & 20,000 & $8.6 \mathrm{E}-05$ & 4.4E-05 \\
\hline $57 \mathrm{G} 133$ & 2011 & Observation & 0 & 0 & 1,140 & 24,000 & 27,000 & 26,000 & $2.5 \mathrm{E}-05$ & $2.3 \mathrm{E}-05$ \\
\hline $57 \mathrm{G} 131$ & 1986 & Production & 50 & 48 & 0 & 840 & nd & nd & nd & nd \\
\hline $58 \mathrm{M} 4$ & 1983 & Production & 130 & 48 & 0 & 1,900 & 800 & 820 & nd & nd \\
\hline \multicolumn{11}{|c|}{ Published reports provided by the Virginia Department of Environmental Quality } \\
\hline $56 \mathrm{G} 69^{1}$ & 1996 & Production & 395 & 48 & 0 & 13,027 & 17,424 & 15,151 & nd & nd \\
\hline $56 \mathrm{G} 29^{1}$ & 1996 & Observation & 0 & 0 & 32.5 & 13,275 & 13,939 & nd & nd & nd \\
\hline $56 \mathrm{G} 72^{2}$ & 1996 & Production & 393 & 48 & 0 & 10,668 & 15,410 & 15,410 & nd & nd \\
\hline $56 \mathrm{G} 15^{2}$ & 1996 & Observation & 0 & 0 & 36.4 & 17,555 & 15,410 & nd & nd & nd \\
\hline $56 \mathrm{G} 80^{3}$ & 2009 & Production & 543 & 48 & 0 & 25,213 & 29,480 & nd & nd & nd \\
\hline $56 \mathrm{G} 79^{3}$ & 2009 & Observation & 0 & 0 & 57 & 29,480 & 30,907 & nd & $1.98 \mathrm{E}-05$ & 8.90E-06 \\
\hline $57 \mathrm{G} 100^{4}$ & 1996 & Production & 365 & 48 & 0 & 13,703 & 16,305 & 15,334 & nd & nd \\
\hline $57 \mathrm{G} 26^{4}$ & 1996 & Observation & 0 & 0 & 30.5 & 12,152 & 12,152 & nd & nd & nd \\
\hline \multicolumn{11}{|c|}{ Maryland Geological Survey Open-File Report 12-02-20 } \\
\hline SM Cd 35 & 1991 & Production & 44 & 24 & 0 & nd & 260 & nd & nd & nd \\
\hline SM Ee 54 & 1992 & Production & 77 & 11 & 0 & nd & 860 & nd & nd & nd \\
\hline SM Ef 95 & 1998 & Production & 62 & 24 & 0 & 690 & 710 & nd & nd & nd \\
\hline SM Eg 36 & 1997 & Production & 70 & 23 & 0 & 970 & nd & nd & nd & nd \\
\hline SM Eg 37 & 1997 & Production & 70 & 23 & 0 & 1340 & nd & nd & nd & nd \\
\hline
\end{tabular}

${ }^{1}$ Russnow-Kane and Associates, 1996c, Report on the hydrogeologic framework and well construction activities at the Norge production well site, Chickahominy-Piney Point aquifer well lot W-24, 15 p.

${ }^{2}$ Russnow-Kane and Associates, 1996b, Report on the hydrogeologic framework and well construction activities at the Kristiansand production well site, Chickahominy-Piney Point aquifer well lot W-38, 15 p.

${ }^{3}$ Russnow-Kane and Associates, 2010, Report on the hydrogeologic framework and well construction activities at the Summerplace production well site, Chickahominy-Piney Point aquifer well lot W-44-1, 13 p.

${ }^{4}$ Russnow-Kane and Associates, 1996a, Report on the hydrogeologic framework and well construction activities at the Canterbury production well site, Chickahominy-Piney Point aquifer well lot W-22, 15 p. 

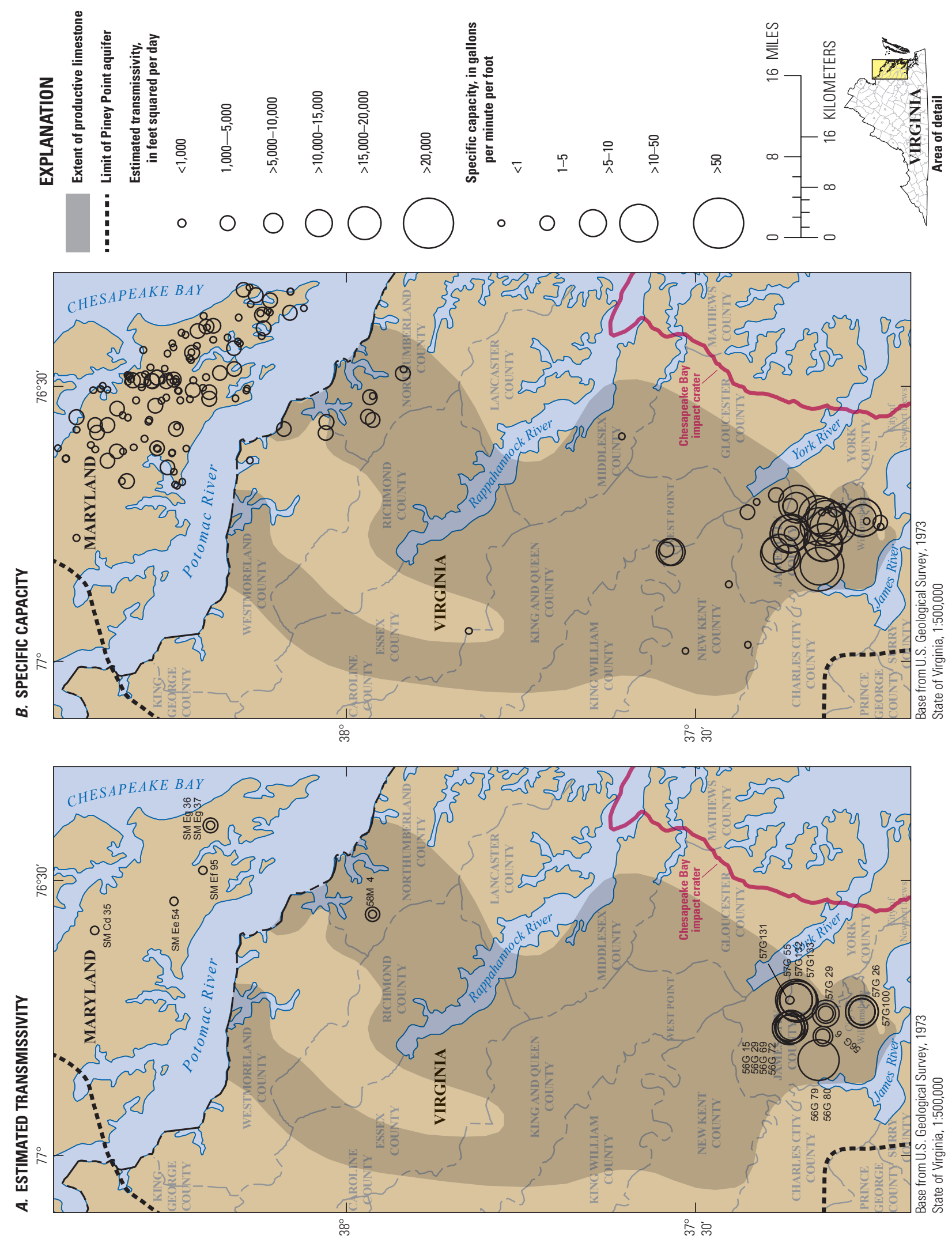

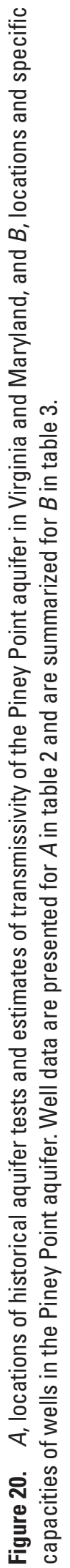




\section{Well Specific Capacity}

In order to further investigate a possible regional trend in the transmissivity of the Piney Point aquifer, measurements of the specific capacities of 176 wells were compiled (fig. 20B). Specific capacity is calculated as the pumping rate of a well divided by its total water-level drawdown. Specific capacity is partly affected by aquifer transmissivity but also by well efficiency. The efficiency of a well is the product of (1) the well diameter and length of screened interval, which jointly determine the surface area of the well screen, (2) the degree of well development, and (3) the age and condition of the well, which can be compromised over time by sediment clogging, chemical corrosion, and loss of structural integrity.

Measurements of well specific capacities were obtained from two sources - the USGS NWIS database and the Maryland Geological Survey (table 3). The USGS NWIS database contains specific capacities for 53 wells open to the Piney Point aquifer, which were identified using a previously documented method (McFarland, 2010) with well-construction data and the regional hydrogeologic framework (McFarland and Bruce, 2006). Records published by the Maryland Geological Survey (Drummond, 1984) contain specific capacities for 123 wells specified as open to the Piney Point aquifer.

Well specific capacities have been measured at a greater number of locations (fig. 20B) than those at which aquifer tests have been conducted (fig. 20A). Specific capacity was measured in 35 wells in the area of large groundwater withdrawals in York and James City Counties. Another 18 wells were measured farther north in Virginia at locations that span five counties in which no aquifer tests were conducted. Measurements of well specific capacity in Maryland have a high spatial density.

The largest specific capacities were measured in wells located in the area of large groundwater withdrawals in York and James City Counties (fig. 20B). These wells have a mean specific capacity of 11.4 gallons per minute per foot (gal/ $\mathrm{min} / \mathrm{ft}$ ) and a range of $0.19-72 \mathrm{gal} / \mathrm{min} / \mathrm{ft}$ (table 3). Specific capacities measured in wells located farther north in Virginia have a smaller mean of $2.26 \mathrm{gal} / \mathrm{min} / \mathrm{ft}$ and a smaller range of $0.12-7.57 \mathrm{gal} / \mathrm{min} / \mathrm{ft}$. Some of these wells have markedly small specific capacities at locations within only a few miles of the area of large groundwater withdrawals. The large number of wells located in Maryland have the smallest specific capacities, with a mean of $0.99 \mathrm{gal} / \mathrm{min} / \mathrm{ft}$ and a small range of $0.2-4 \mathrm{gal} / \mathrm{min} / \mathrm{ft}$.

Specific capacities of wells open to the Piney Point aquifer apparently decrease northward. This trend is probably unrelated to well efficiency. Among wells located in Virginia, specific capacity is not correlated with well-screen surface area (correlation coefficient 0.04 ). In addition, the mean screen surface area of $40.6 \mathrm{ft}^{2}$ among wells located in the area of large withdrawals is actually slightly less than the mean screen surface area $49.1 \mathrm{ft}^{2}$ for wells located farther north in Virginia. Well development, age, and condition which also affect well efficiency, are likely random and without a spatial trend.

Rather than well efficiency, the northward decrease in specific capacity more likely reflects a northward decrease in aquifer transmissivity resulting from poor development of the solution-channeled limestone of the Piney Point Formation (see section "Historical Aquifer Tests"). On the basis of markedly small specific capacities within only a few miles of the area of large groundwater withdrawals in York and James City Counties, transmissivity of the Piney Point aquifer possibly decreases abruptly northward.

\section{Aquifer-Component Test}

A specialized aquifer test was conducted by the VADEQ during March 2015 to determine hydraulic properties of, and flow interaction between, geologic units that compose the Piney Point aquifer. This aquifer test was conducted at a groundwater research station constructed by the VADEQ in northern York County.

\section{Groundwater Research Station}

The groundwater research station is located at observation wells 57G129 and 57G130 (fig. 18). This location is on the York-James Peninsula and is bounded by the York River

Table 3. Summary of well specific capacities in the Piney Point aquifer in Virginia and an adjacent part of Maryland.

[gal/min/foot, gallons per minute per foot]

\begin{tabular}{|c|c|c|c|c|c|}
\hline \multirow[t]{2}{*}{ Area } & \multirow{2}{*}{$\begin{array}{l}\text { Number } \\
\text { of wells }\end{array}$} & \multirow[t]{2}{*}{ Data source } & \multicolumn{3}{|c|}{$\begin{array}{l}\text { Well specific capacity } \\
\text { (gal/min/foot) }\end{array}$} \\
\hline & & & Mean & Minimum & Maximum \\
\hline $\begin{array}{l}\text { York and James City } \\
\text { Counties }\end{array}$ & 35 & U.S. Geological Survey National Water Information System & 11.4 & 0.19 & 72 \\
\hline $\begin{array}{l}\text { North of York and } \\
\text { James City Counties }\end{array}$ & 18 & U.S. Geological Survey National Water Information System & 2.26 & 0.12 & 7.57 \\
\hline Maryland & 123 & Maryland Geological Survey Basic Data Report 14 & 0.99 & 0.2 & 4 \\
\hline
\end{tabular}


approximately $3 \mathrm{mi}$ to the northeast and the James River $10 \mathrm{mi}$ to the southwest (fig. 1).

Litho-stratigraphy at the groundwater research station is based on the Banbury Cross corehole (USGS well 57G128; plate 1; Appendix 1; McFarland, 2017) from which a continuous sediment core was obtained by the VA DEQ during 2014. The sediment core intersected all geologic units that compose the Piney Point aquifer (figs. 4 and 21), except Gosport Formation equivalent sediments and Oligocene-age sediments, which pinch out approximately $20 \mathrm{mi}$ to the northeast (see section "Hydrogeologic Framework").

Land-surface altitude is approximately $80 \mathrm{ft}$ and the bottom of the corehole is $-265 \mathrm{ft}$ (fig. 21). The Piney Point aquifer ranges in altitude from -148 ft to $-204 \mathrm{ft}$ and is entirely confined. Interbedded limestone and sand of the Piney Point Formation is present between $-182 \mathrm{ft}$ and $-197 \mathrm{ft}$. The Piney Point aquifer is underlain by at least $61 \mathrm{ft}$ of fine-grained sediment that composes the Nanjemoy-Marlboro confining unit. The Piney Point aquifer is overlain by $145 \mathrm{ft}$ of fine-grained sediment that composes the Calvert confining unit and overlying Saint Marys confining unit. The relatively shallow surficial aquifer, Yorktown confining zone, and Yorktown-Eastover aquifer collectively range in altitude from $80 \mathrm{ft}$ to $-3 \mathrm{ft}$.

Preexisting production well $57 \mathrm{G} 131$ is sited at the groundwater research station and is cased with 4-inch (in.) -diameter steel into the top of interbedded limestone and sand of the Piney Point Formation (fig. 21). Only the uppermost $50 \mathrm{ft}$ of the casing is grouted. Below the casing, the well consists of an 8-in. diameter open borehole in the limestone and sand, commonly referred to as a "barefoot" well (see section "Piney Point Formation"). The open interval is mostly in interbedded limestone and sand of the Piney Point Formation, but it is also in the underlying sand of the Nanjemoy Formation Woodstock Member. A single-well aquifer drawdown test of well 57G131 was conducted in 1986 (see section "Historical Aquifer Tests").

Production well $57 \mathrm{G} 131$ was augmented by observation wells $57 \mathrm{G} 129$ and $57 \mathrm{G} 130$ (figs. $18 E$ and 21) constructed by the VA DEQ during early 2015. Observation wells 57G129 and $57 \mathrm{G} 130$ are positioned $33 \mathrm{ft}$ and $26 \mathrm{ft}$, respectively, from production well 56G131. Both observation wells are cased with 4.5-in.-diameter, fully grouted polyvinyl chloride (PVC), below which are gravel-packed 4-in.-diameter PVC screens with 0.020 -in. slots.

Observation-well open intervals are positioned to distinguish between geologic units that compose the Piney Point aquifer. The open intervals are shown (fig. 21) as the 9-in.-diameter gravel-packed intervals, which extend above and below the ends of the well screens. Well 57G129 is open entirely within interbedded limestone and sand of the Piney Point Formation. Well 57G130 is open mostly to the silty sand of the Calvert Formation, Newport News unit and basal Plum Point Member but also to part of the overlying sandy clay, silt of the Calvert Formation fine-grained Plum Point Member.

\section{Pumping and Water-Level Measurement}

Production well 57G131 was not active during 2015, except when pumped during the aquifer test. Continuous (2-min interval) measurements of water levels in observation wells 57G129 and 57G130 that are stored in the USGS NWIS database began on March 3, 2015 (fig. 18A). The research station is sited within the area of large groundwater withdrawals and an associated water-level cone of depression in James City and northern York Counties (see section "Water-Level Cone of Depression"). As a result, water levels in both observation wells were affected during early March and April-September 2015 by cyclical pumping of two nearby active municipal-supply production wells (see section "WaterLevel Interactions on the York-James Peninsula"). Production well $57 \mathrm{G} 55$ is approximately $0.6 \mathrm{mi}$ to the south, and production well $57 \mathrm{G} 134$ is approximately $1.3 \mathrm{mi}$ to the southwest (fig. 18E).

Arrangements were made so that water levels at the groundwater research station would not be affected by the municipal-supply production wells during aquifer testing. Following initial background water-level measurements during early March, pumping of production wells 57G 55 and 57G134 was discontinued on March 10 to allow observationwell water levels to recover prior to the aquifer test (fig. 18A). Recovery was partially interrupted twice. Maintenance of the water-supply system required resumption of pumping of production wells 57G 55 and 57G134 briefly during March 13-14 for filling of water-storage tanks. A second interruption on March 16 resulted from the pumping of production well $57 \mathrm{G} 131$ at the groundwater research station for a series of short tests of a flow meter installed for the aquifer test.

In addition to water levels measured and stored in the USGS NWIS database, the VADEQ measured water levels at 1 -second intervals in both observation wells prior to and during the aquifer test (fig. 22A) (Appendix 2; McFarland, 2017). These high temporal resolution measurements exhibited a sinusoidal periodicity during pre-test recovery of observation well 57G129 that was superimposed on the rising water level. A similar but more muted trend was exhibited by observation well 57G130.

Observation-well water-level measurements by the VADEQ continued during a 24-hour aquifer drawdown test begun on March 17 (fig. 22A). Production well 57G131 was pumped at a constant rate of $61 \mathrm{gal} / \mathrm{min}$ but was not continuously measured for water levels because of constrained access to the interior of the well. Water levels in observation well 57G129 declined approximately from $124.35 \mathrm{ft}$ below land surface to $125.10 \mathrm{ft}$ below land surface. Water levels in observation well 57G130 declined more slowly and slightly less, approximately from $124.40 \mathrm{ft}$ below land surface to $125.05 \mathrm{ft}$ below land surface. As pumping continued, water levels in both wells began to stabilize and exhibit a sinusoidal periodicity similar to that during the pre-test recovery period. 


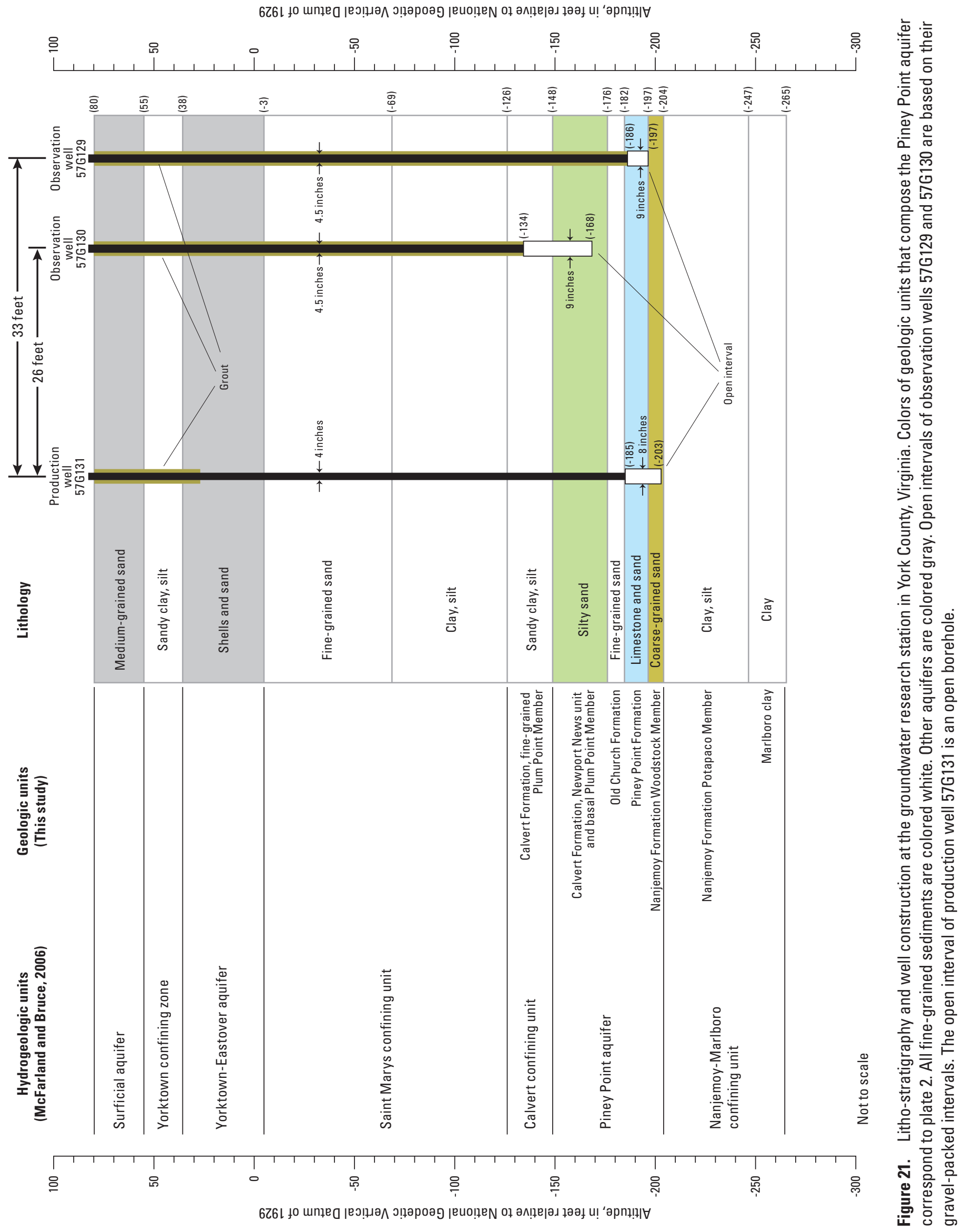



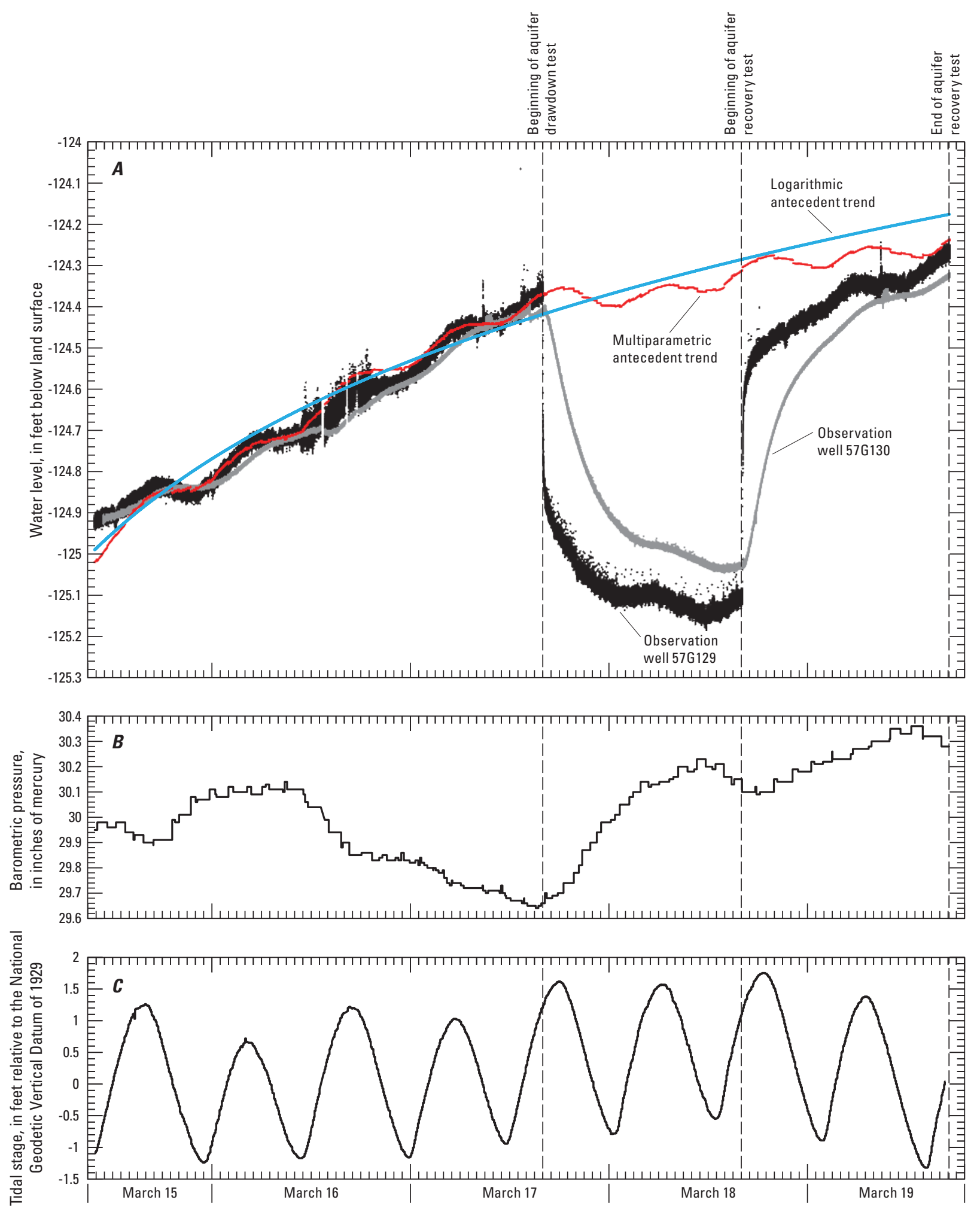

Figure 22. $A$, Data collected prior to and during an aquifer test at the groundwater research center in York County, Virginia, for observation-well water levels and antecedent water-level trends, $B$, barometric pressure downloaded on September 23, 2015, from Weather Underground weather stations KVAWILL119, KVAWILL120, and KVAOILL121, and C, tidal stage of James River at the U.S. Geological Survey gaging station 02042222 in Charles City County, Virginia, during March 15-19, 2015. 
Pumping of production well 57G131 was discontinued after 24 hours to begin an aquifer recovery test (fig. 22A). Water levels in both observation wells rose in a manner similar to their decline during the drawdown test. After another 24 hours, the recovery test was discontinued when municipalsupply production wells 57G 55 and 57G134 were reactivated.

Following the aquifer drawdown and recovery tests, water levels in both observation wells were affected by cyclical pumping of the municipal-supply production wells in a manner similar to that during early March (fig. 18A). Water levels remained higher, however, than those prior to the pre-test recovery period. Water levels in wells 57G129 and 57G130 and other observation wells in the Piney Point aquifer exhibit a seasonal trend that results from a seasonal demand that occurred for the public drinking-water system (see section "Seasonal Water Demand"). This seasonal trend was interrupted in observation wells 57G129 and 57G130 by the pre-test recovery imposed at the groundwater research station. Following the aquifer test, water levels at the research station apparently did not readjust to the seasonal trend until early April.

\section{Antecedent Water-Level Depth Trend}

Analysis of the aquifer test required calculation of waterlevel drawdowns and recoveries from the measured waterlevel depths below land surface. If water levels prior to the aquifer test had been stable, drawdowns and recoveries could be calculated simply as the difference between water-level depths during the test and the water-level depth at the beginning of the test. Water levels were rising during the pre-test period, however, and exhibited a superimposed sinusoidal periodicity (see section "Pumping and Water-Level Measurement"). Water levels would have continued this antecedent trend had the aquifer test not been conducted. Consequently, drawdowns and recoveries from the aquifer test are the differences between water-level depths during the test and waterlevel depths at corresponding times that would have continued the antecedent trend.

In order to calculate water-level drawdowns and recoveries, an estimate was made of the antecedent water-level depth trend in observation well 57G129 during the aquifer test. The water-level depth trend during the pre-test period was first approximated on the basis of measured water-level depths, then was extrapolated during the aquifer test. Because water levels were affected by filling of water-storage tanks during March 13-14, pre-test water-level depths were used from March 15 to the beginning of the aquifer test on March 17 (fig. 22A). Brief water-level fluctuations resulting from tests of a flow meter during March 16 also were omitted from the measured water-level depths.

A method of successive approximation was used to determine the pre-test water-level depth trend in observation well 57G129. Initially, measured pre-test water-level depths were fitted by a logarithmic regression equation having the formula

$$
y=0.507 \ln (x)-130.79
$$

where

$$
\begin{aligned}
& y \text { is the approximate water-level depth, in } \mathrm{ft} \text {, } \\
& \text { and } \\
& x \text { is time, in seconds. }
\end{aligned}
$$

This equation strongly correlates water-level depths measured during the pre-test recovery period $\left(r^{2}=0.95\right)$. It generally approximates the rising water levels but does not account for the superimposed sinusoidal periodicity (fig. 22A). Extrapolation of the logarithmic trend during the aquifer test also estimates water levels that are approximately $0.1 \mathrm{ft}$ higher than those measured by the end of the aquifer test.

Accuracy of the logarithmic estimate of the antecedent water-level depth trend in observation well 57G129 was improved by accounting for the effects of barometric pressure and tides. Water levels in wells that are open to confined aquifers are in hydrostatic equilibrium with the overlying atmosphere. Changes in atmospheric pressure thereby produce inverse changes in water levels. In addition, loading and unloading of the earth's surface by tidal surface water can produce direct changes in well water levels. Accordingly, continuously measured barometric pressure was downloaded on September 23, 2015, from the wunderground.com websites for weather stations KVAWILLI19, KVAWILLI20, and KVAWILLI21 (fig. 22B; Appendix 2; McFarland, 2017). Barometric pressure was initially close to 30 in. on March 15, declined to nearly 29.6 in. on March 17 , then rose to nearly 30.4 in. by March 19. Continuously measured tide stages also were compiled from the USGS NWIS database for the estuarine James River at USGS gaging station 02042222 in Charles City County (fig. 22C; Appendix 2; McFarland, 2017). Tide stage fluctuated regularly by approximately $2.5 \mathrm{ft}$.

In order to improve the accuracy of the antecedent waterlevel depth trend estimate, residual values calculated as the difference between measured and logarithmically approximated water-level depths were approximated using variations in barometric pressure and the equation

$$
y=-0.150(x)+4.4925
$$

where

$$
\begin{aligned}
& y \text { is the approximate residual value, in } \mathrm{ft} \text {, and } \\
& x \text { is barometric pressure, in inches. }
\end{aligned}
$$

In turn, a second set of residual values calculated as the difference between barometrically and logarithmically approximated residual values was approximated using variations in tide stage with the equation

$$
y=0.0159(x)+0.0003
$$

where

$y \quad$ is the approximate residual value, in $\mathrm{ft}$, and

$x \quad$ is the tide stage, in $\mathrm{ft}$, lagged by 5.5 hours

from corresponding water-level measurements. 
Logarithmically approximated water-level depths were summed with barometrically and tide-stage approximated residuals to produce a multiparametric estimate of the antecedent water-level depth trend in observation well 57G129 (fig. 22A; Appendix 2; McFarland, 2017). This estimate generally approximates rising water levels during the pre-test recovery period. In addition, the superimposed sinusoidal periodicity is generally accounted for probably as an effect of tides (fig. 22C). Extrapolation of the multiparametric trend during the aquifer test also estimates water levels that are within the measured range near the end of the aquifer test and lower than that estimated by the logarithmic trend alone. Water levels during the aquifer test were probably lowered progressively by the increase in barometric pressure (fig. 22B).

\section{Water-Level Drawdown and Recovery}

Water-level drawdowns and recoveries in observation well $57 \mathrm{G} 129$ imposed by the aquifer test were calculated as the difference between measured water-level depths below land surface and multiparametric estimates of antecedent water-level depths at corresponding times during the test (fig. 23; Appendix 2; McFarland, 2017). An approximate loglinear trend with respect to time is apparent during both the drawdown and recovery tests, except for the first 10 seconds, which were affected by release from well-bore storage and are omitted.

The rate of water-level change in observation well $57 \mathrm{G} 129$ during the aquifer test is reflected by the slopes of the drawdown and recovery trends. Both trends changed slope twice to divide each test into three periods (fig. 23). Log-linear regression lines were fitted to drawdowns and recoveries for each of the three periods. The decrease in slope of the drawdown and recovery trends between period 1 and period 2 is probably the result of the change in aquifer response from a single layer to two layers (see section "Conceptual Two-Layer Aquifer Model").

The slope of the drawdown trend increased between period 2 and period 3 (fig. 23A). The slope of the recovery trend initially decreased during period 3 but then increased during most of period 3 (fig. 23B). Increased slopes of the drawdown and recovery tests during period 3 reflect a faster rate of water-level change and a reduction in the source of water to the pumped well. Similar increases were observed during previously conducted aquifer tests (see section "Historical Aquifer Tests") at (1) production well 57G131 prior to construction of the groundwater research station, (2) production well $57 \mathrm{G} 55$ sited approximately $0.6 \mathrm{mi}$ to the south of the research station (fig. 18E), and (3) production well 57G100 sited approximately $7 \mathrm{mi}$ to the south (fig. 20A).

The increase in the slope of the drawdown and recovery trends between period 2 and period 3 is probably the result of interception of a fault-associated no-flow boundary. A high-angle to vertical fault near the groundwater research station (fig. 18E) was interpreted from stratigraphic correla- tion and structure-contour mapping (see section "Hydrogeologic Framework"). Vertical displacement across this fault is estimated to be as much as $50 \mathrm{ft}$, which is more than twice the thickness of the limestone and sand of the Piney Point Formation. Faults that intersect the Piney Point aquifer are generally recognized to produce various hydraulic effects (see section "Faults"). Lateral continuity of the limestone and sand is likely interrupted along the fault near the groundwater research station, which creates a vertically dislocated flow barrier where the Piney Point Formation is truncated by adjacent geologic units. Potentially many more faults are present but have not been recognized because of sparse borehole data and inadequate spatial control.

\section{Conceptual Two-Layer Aquifer Model}

The slopes of the drawdown and recovery trends in observation well 57G129 decreased between period 1 and period 2 probably because of a change in the response of the Piney Point aquifer from a single layer to two layers. Flow and water-level response of a two-layer confined aquifer to pumping has been theorized (Javandel and Witherspoon, 1983; Kruseman and de Ridder, 2000). Early response of the aquifer differs from late response. Initially upon pumping, flow and water-level decline take place only in the aquifer layer being pumped (fig. 24A). During this period drawdown is a function of the transmissivity solely of the pumped layer $\left(T_{1}\right)$. Assuming that other conditions are met (see section "Assumptions and Limitations"), drawdown will exhibit a log-linear trend with respect to time.

With continued pumping, vertical leakage and waterlevel decline are induced at a later time in the unpumped layer (fig. 24B). The unpumped layer thereby provides an additional source of water to the pumped well. Drawdown is now a function of the sum of the transmissivities of both layers $\left(T_{1+2}\right)$. Assuming that other conditions are met, drawdown will continue to exhibit a log-linear trend but have a lower slope than during the earlier period, which reflects the slower rate of drawdown. Water-level response during recovery is the inverse of that during drawdown.

On the basis of the conceptual two-layer aquifer model, transmissivities of the layers can be distinguished. Initial drawdown and recovery can be analyzed to estimate the transmissivity of the pumped aquifer layer ( $T_{1}$; fig. 24A). Likewise, late drawdown and recovery can be analyzed to estimate the sum of the transmissivities of both layers $\left(T_{1+2} ;\right.$ fig. $\left.24 B\right)$. From these estimates, the transmissivity of the unpumped layer can be estimated as

$$
T_{2}=T_{1+2}-T_{1}
$$

In order to estimate the transmissivity of both aquifer layers, the early period must be distinguished from the late period. At the groundwater research station, interbedded limestone and sand of the Piney Point Formation generally 

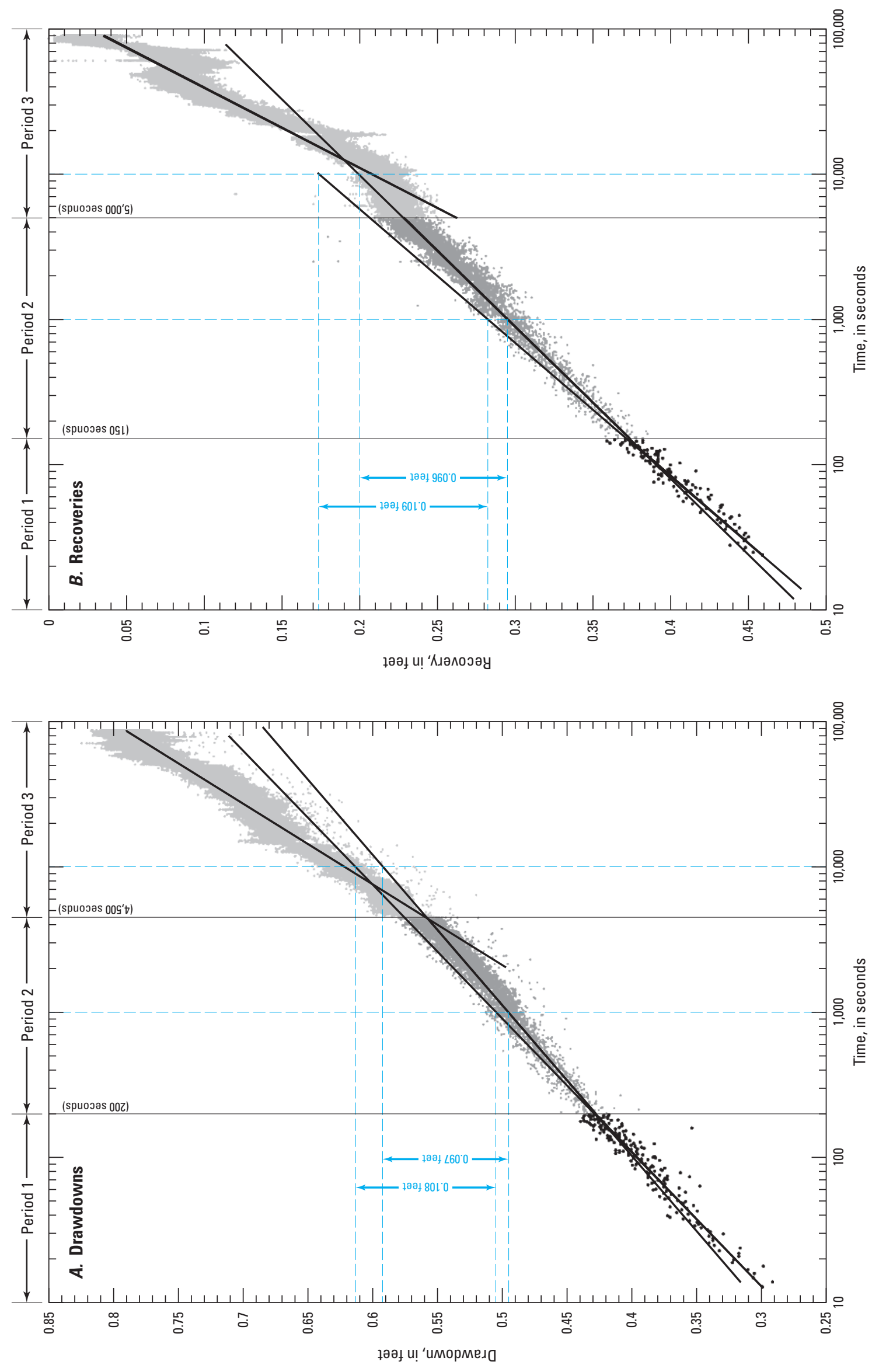

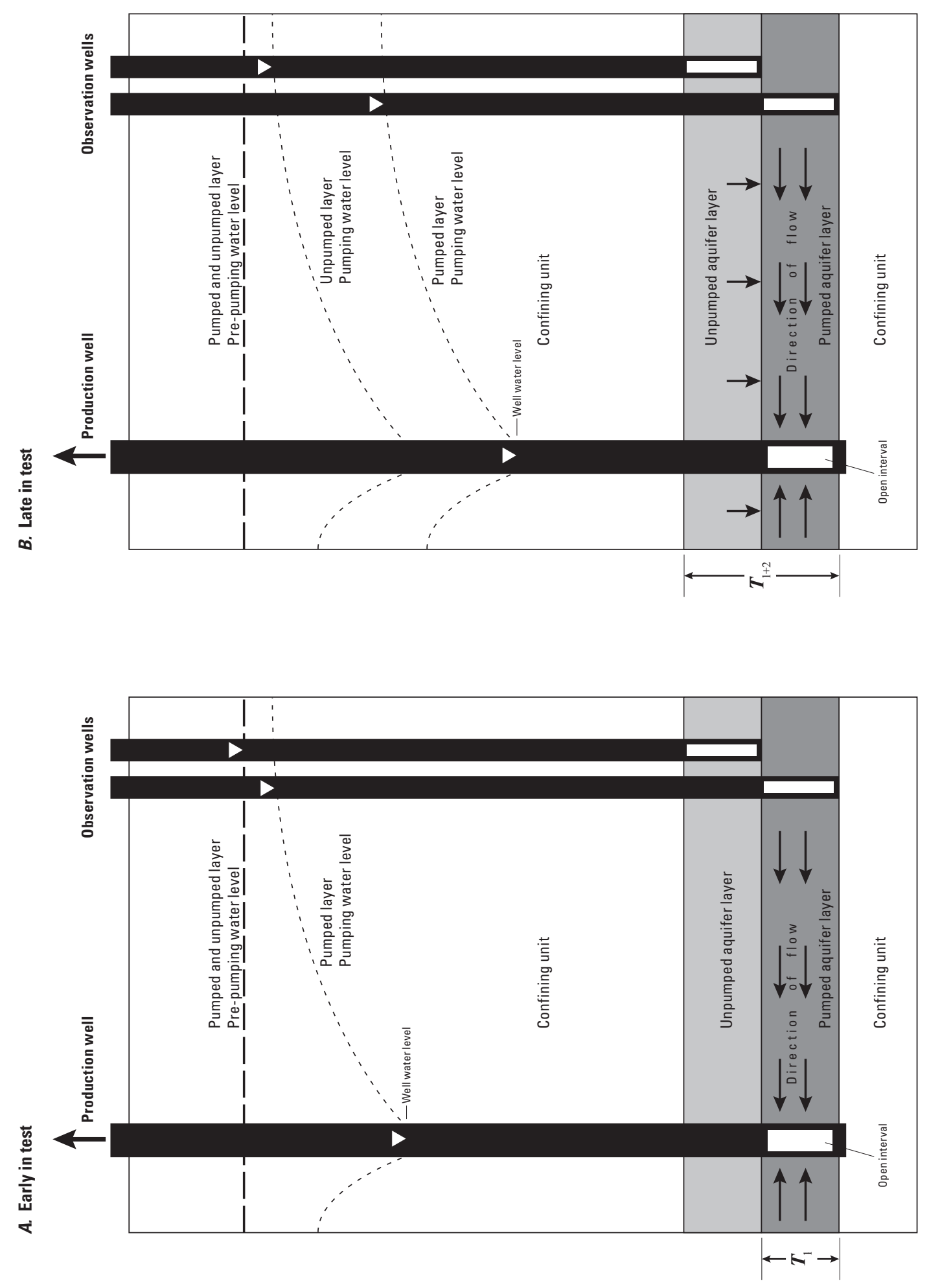

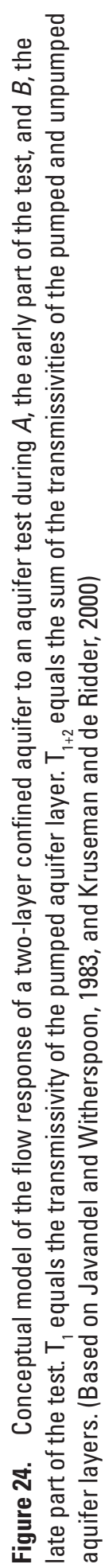


represent the pumped layer. Observation well 57G129 is open to the limestone and sand (fig. 21) and exhibited drawdown and recovery trends that decreased in slope at 200 seconds and 150 seconds, respectively (fig. 23).

In addition, water levels measured in observation well 57G130 during the aquifer test can provide a second independent estimate of the timing between the early and late periods. Well $57 \mathrm{G} 130$ is open mostly to silty sand of the Calvert Formation, Newport News unit and basal Plum Point Member, which was not pumped during the aquifer test. Water-level decline in well 57G130 reflects vertical leakage from the silty sand that was induced by pumping of the underlying limestone and sand. Water levels in well 57G130 lagged behind those in well 57G129 (fig. 22A). Exact timing of the onset of decline in well $57 \mathrm{G} 130$ is obscured by random water-level fluctuations of as much as several hundredths of a foot between successive 1-second interval measurements. The trend of a 60 -second moving average calculated from the water levels, however, indicates that the onset of decline is between 100 and 300 seconds. Hence, the similar timing of decreases in slope of the drawdown and recovery trends in well 57G129 at 200 seconds and 150 seconds probably represents the change in the response of the Piney Point aquifer from a single layer to two layers.

\section{Geologic-Unit Transmissivities and Hydraulic Conductivities}

Transmissivities and horizontal hydraulic conductivities of geologic units that compose the Piney Point aquifer were estimated on basis of the conceptual two-layer aquifer model and changes in slope of the drawdown and recovery trends in observation well 57G129. Estimates were made from the first 4,500 seconds ( $75 \mathrm{~min}$.) of the drawdown test and from the first 5,000 seconds (83.33 min.) of the recovery test (periods 1 and 2; fig. 23). Later drawdowns and recoveries (period 3) probably were increased by interception of a fault-associated no-flow boundary (see section "Water-Level Drawdown and Recovery") and were not used.

Transmissivities were estimated (table 4) using the graphical method of Cooper and Jacob (1946). The change in water level, in $\mathrm{ft}$ per log cycle of time, was approximated from a log-linear regression line fitted to each of the test periods (fig. 23). From the drawdowns and recoveries during period 1, transmissivities were calculated for interbedded limestone and sand of the Piney Point Formation in which pumping took place. From period 2, the sums of the transmissivities were calculated for the limestone and sand and the overlying silty sand of the Calvert Formation, Newport News unit and basal Plum Point Member, which was not pumped. Differences between these values were then calculated as transmissivities of the silty sand.

Horizontal hydraulic conductivities of interbedded limestone and sand of the Piney Point Formation, and of silty sand of the Calvert Formation, Newport News unit and basal Plum Point Member also were calculated (table 4) from the transmissivity estimates and the thicknesses of the geologic units (fig. 21). Unlike transmissivity, hydraulic conductivity accounts for the different thicknesses of the geologic units and thereby gives a more direct comparison between the sediment textures.

Table 4. Estimates of the transmissivities and hydraulic conductivities of geologic units composing the Piney Point aquifer, using aquifer testing at the groundwater research station in York County, Virginia, March 2015.

[na, not applicable]

\begin{tabular}{|c|c|c|c|c|c|c|c|}
\hline Geologic unit & $\begin{array}{c}\text { Test } \\
\text { period }\end{array}$ & \multicolumn{3}{|c|}{ Drawdown test } & \multicolumn{3}{|c|}{ Recovery test } \\
\hline $\begin{array}{l}\text { Combined limestone and sand } \\
\text { of the Piney Point Formation } \\
\text { and silty sand of the Calvert } \\
\text { Formation, Newport News unit } \\
\text { and basal Plum Point Member }\end{array}$ & 2 & 0.097 & 22,300 & na & 0.096 & 22,400 & na \\
\hline
\end{tabular}


Transmissivities and horizontal hydraulic conductivities estimated from drawdowns differed only slightly from those estimated from recoveries (table 4). Transmissivity of interbedded limestone and sand of the Piney Point Formation was estimated from drawdowns to be $19,900 \mathrm{ft}^{2} / \mathrm{d}$ and from recoveries to be $19,800 \mathrm{ft}^{2} / \mathrm{d}$. Horizontal hydraulic conductivity of the limestone and sand was calculated from drawdowns to be 0.92 feet per minute $(\mathrm{ft} / \mathrm{min})$ and from recoveries to be $0.91 \mathrm{ft} / \mathrm{min}$. By contrast, transmissivity of silty sand of the Calvert Formation, Newport News unit and basal Plum Point Member was estimated from drawdowns to be only 2,400 ft' $/ \mathrm{d}$ and from recoveries to be $2,600 \mathrm{ft}^{2} / \mathrm{d}$, nearly an order of magnitude less than the limestone and sand. Horizontal hydraulic conductivity of the silty sand was more than an order of magnitude less, calculated from drawdowns to be $0.06 \mathrm{ft} / \mathrm{min}$ and from recoveries to be $0.07 \mathrm{ft} / \mathrm{min}$. These contrasts are consistent with the different sediment textures of these geologic units (see section "Geologic Units").

For comparison, a single-well aquifer drawdown test was conducted for production well 57G131 upon its completion in 1986 but 29 years prior to construction of the collocated groundwater research station (see section "Historical Aquifer Tests"). The earlier aquifer test resulted in an estimated a transmissivity of $840 \mathrm{ft}^{2} / \mathrm{d}$ (table 2 ), which is considerably less than that estimated for this study. The earlier test used a pumping rate of $50 \mathrm{gal} / \mathrm{min}$, which is only marginally different from the $61 \mathrm{gal} / \mathrm{min}$ used here. During the intervening 29 years, however, prolonged pumping of water for production possibly substantially developed well $57 \mathrm{G} 131$ following the early aquifer test. In addition, the median estimate of transmissivity from aquifer tests of other parts of the Piney Point aquifer within Virginia is $15,410 \mathrm{ft}^{2} / \mathrm{d}$, which is similar to the estimates obtained for this study.

For further comparison, published estimates of the horizontal hydraulic conductivity of the Piney Point aquifer range across two orders of magnitude from $0.001 \mathrm{ft} / \mathrm{min}$ to $0.49 \mathrm{ft} / \mathrm{min}$ (Hamilton and Larson, 1988). These estimates were indirectly derived, however, either from well specificcapacity tests or from groundwater-model calibration, which integrated all geologic units that compose the Piney Point aquifer. Hence, the published horizontal hydraulic conductivity estimates bracket those obtained for this study for silty sand of the Calvert Formation, Newport News unit and basal Plum Point Member but are exceeded by those for limestone and interbedded sand of the Piney Point Formation.

\section{Assumptions and Limitations}

Validity of the graphical aquifer-test analysis method of Cooper and Jacob (1946) requires the assumptions that (1) the aquifer has infinite areal extent; (2) the aquifer is homogeneous, isotropic and of uniform thickness; (3) the production well fully penetrates the aquifer; (4) flow to the production well is horizontal; (5) the aquifer is confined; (6) flow is unsteady; (7) water is released instantaneously from storage; (8) the diameter of the production well is small; and (9) time is large or the distance from the production well to the observation well is small. Conditions of the aquifer test generally meet these assumptions. Although a fault-associated no-flow boundary infers that the Piney Point aquifer is not of infinite areal extent (see section "Water-Level Drawdown and Recovery"), drawdowns and recoveries that were probably affected by this boundary during test period 3 were not used in estimating transmissivity. Likewise, drawdowns and recoveries during the first 10 seconds that were affected by release from wellbore storage were not used. Drawdowns and recoveries during periods 1 and 2 occurred after release from well-bore storage and before interception of the no-flow boundary, and provide generally valid estimates of transmissivity.

On the basis of the conceptual two-layer aquifer model, interbedded limestone and sand of the Piney Point Formation generally represent the pumped layer. Production well 57G131 penetrates most of the limestone and sand but also part of the underlying sand of the Nanjemoy Formation Woodstock Member (fig. 21). This sand has a similar texture to sand that is interbedded with limestone of the Piney Point Formation. Hence, the two geologic units probably function hydraulically as a continuous medium through which water moves essentially uninterrupted.

Validity of the conceptual two-layer aquifer model requires the assumption that the aquifer layers are in direct contact (fig. 24). As applied here, interbedded limestone and sand of the Piney Point Formation generally represent the pumped layer, and overlying silty sand of the Calvert Formation, Newport News unit and basal Plum Point Member represents the unpumped layer. At the groundwater research station, however, these geologic units are vertically separated by a relatively thin interval of fine-grained sand of the Old Church Formation (fig. 21). The fine-grained sand is probably relatively restrictive of flow and possibly impeded the onset and magnitude of vertical leakage from the silty sand to the limestone and sand during the aquifer test. Although this effect is probably negligible, transmissivity and horizontal hydraulic conductivity of the silty sand could be underestimated.

Lastly, observation well $57 \mathrm{G} 130$ is open mostly to silty sand of the Calvert Formation, Newport News unit and basal Plum Point Member but also to part of the overlying sandy clay, silt of the fine-grained Calvert Formation Plum Point Member. Water-level decline in well 57G130 probably primarily reflects vertical leakage from the silty sand that was induced by pumping of underlying interbedded limestone and sand of the Piney Point Formation. Considering contrasts in sediment texture, any additional water leaked from the sandy clay, silt is likely to be negligible. 


\section{Water Quality}

The chemical composition of water in the entire Piney Point aquifer in the Virginia Coastal Plain has been previously described (McFarland, 2010). Previously compiled hydrochemical data for the designated study area surrounding the productive limestone of the Piney Point aquifer are selectively summarized here (see section "Introduction"). New interpretations are also presented to elucidate aspects that are particular to the Piney Point aquifer.

Hydrochemical data on the Piney Point aquifer within the study area have a median $\mathrm{pH}$ value that is slightly alkaline, 8.0, and a median dissolved solids value (reported as filtered residue) that is moderate, 226 milligrams per liter $(\mathrm{mg} / \mathrm{L})$ (McFarland, 2010). Analyses of chemical tracers indicate the ages of water in the Piney Point aquifer range from 20,000 years to 37,000 years (Nelms and others, 2003). Water in most of the Piney Point aquifer generally is considered desirable for most uses. Some limitations can potentially result from elevated concentrations of iron and sulfide, or chloride.

\section{Major lons}

The hydrochemical composition of most of the Piney Point aquifer is consistently dominated by sodium cations with a median concentration of $41.5 \mathrm{mg} / \mathrm{L}$ and bicarbonate anions with a median concentration of $135 \mathrm{mg} / \mathrm{L}$ (McFarland, 2010). Other major cations include calcium (median concentration $15.0 \mathrm{mg} / \mathrm{L}$ ), magnesium (median concentration $2.7 \mathrm{mg} / \mathrm{L}$ ) and potassium (median concentration $7.9 \mathrm{mg} / \mathrm{L}$ ). Other major anions include carbonate (median concentration $13.0 \mathrm{mg} / \mathrm{L}$ ), sulfate (median concentration $6.9 \mathrm{mg} / \mathrm{L}$ ), and chloride (median concentration $4.2 \mathrm{mg} / \mathrm{L}$ ).

Water in the Piney Point aquifer originated as precipitation that infiltrated the land surface and underwent processes that controlled its chemical composition as it flowed through the subsurface. The water first came in contact with soil organic matter to form carbonic acid, which then dissolved minerals making up subsurface sediments. The chemical composition of shallow groundwater in the Virginia Coastal Plain is thereby typically dominated by calcium cations and bicarbonate anions (McFarland, 2010). With further lateral flow and downward leakage, however, deeper water has undergone cation exchange with clay minerals and glauconite that removed calcium from solution by adsorption and released sodium into solution (Foster, 1950). Additional dissolution of minerals has taken place in the subsurface, particularly within the Piney Point aquifer where calcite composes the limestone of the Piney Point Formation. Cation exchange has also continued, however, to adsorb calcium and release sodium.

\section{Solution Channeling}

The limestone of the Piney Point Formation exhibits well developed solution channeling that is largely attributed for the productivity of the Piney Point aquifer (see section
"Piney Point Formation"). Throughout earth history, limestone and other carbonate sedimentary rocks have generally been deposited in warm shallow ocean basins. Deposition and subsequent diagenesis of limestone involve complex processes that are beyond the scope of this report. Some insight into the formation of solution channels in limestone of the Piney Point Formation, however, can be gained by examination of the chemical composition of water now present in the limestone.

Dissolution of calcite that composes the limestone produces calcium cations and bicarbonate anions. On the basis of theromodynamic equilibria (Freeze and Cherry, 1979), however, water tends to dissolve a particular mineral only until the concentrations of the ions being produced reach the point of saturation, at which dissolution will cease. Likewise, solutions having higher concentrations are said to be supersaturated and tend to precipitate the mineral. The degree of saturation with respect to a particular mineral can be assessed by the saturation index (SI), which is calculated from the concentrations of the associated ions and related mineral-solubility data. Concentrations below saturation produce SI values less than zero, at saturation produce a value of zero, and above saturation produce values greater than zero.

Accordingly, SI values with respect to calcite were calculated using the computer program WATEQ4F (Ball and Nordstrom, 1991) and compiled hydrochemical data for 34 water samples collected from 21 wells open to the Piney Point aquifer within or in proximity to the limestone (McFarland, 2010). Median SI values range from -9.1 to 0.9 , with an overall median of -0.6. In addition, median values for 14 of the wells are between -1.9 and zero. Thus, most of the samples are slightly undersaturated with respect to calcite.

Given the prevalence of solution channels in the limestone, dissolution of calcite has clearly been an active hydrochemical process in the Piney Point aquifer. Incongruously, concentrations of calcium cations and bicarbonate anions have generally not fully reached saturation with respect to calcite. As calcium ions are produced, however, they are likely removed from solution by adsorption and replaced by sodium (Foster, 1950). Cation exchange is facilitated by clay minerals and especially glauconite, which is a dominant lithologic component of the limestone. The solution is thereby maintained below saturation with respect to calcite and is capable of continuing to dissolve calcite and form solution channels to a pronounced degree.

\section{Iron}

Withdrawals from the Piney Point aquifer are primarily made from the limestone of the Piney Point Formation, rather than other geologic units, in part, because of its greater production capacity but also because of its more desirable hydrochemical quality. Silty sand of the Calvert Formation, Newport News unit and basal Plum Point Member, however, is the most widespread geologic unit composing the aquifer (see section "Calvert Formation, Newport News unit and basal Plum Point Member"). The silty sand overlies the limestone 
throughout the study area. Beyond the extent of the limestone, silty sand entirely composes much of the Piney Point aquifer outside the study area. In contrast to the limestone, the hydrochemical composition of the silty sand is known anecdotally to have elevated concentrations of iron and hydrogen sulfide, which are generally considered undesirable for water supplies. Iron produces staining, clogging, and corrosion of plumbing, and hydrogen sulfide has a strong unpleasant odor.

Concentrations of hydrogen sulfide in water in the Piney Point aquifer have not been widely determined, but concentrations of iron were compiled for 104 water samples collected from 52 wells located within the study area and open to the Piney Point aquifer (fig. 25) (McFarland, 2010). Of the 104 samples, 83 that were collected from 44 wells exhibited iron concentrations below the secondary drinking-water standard (U.S. Environmental Protection Agency, 1990) of $0.3 \mathrm{mg} / \mathrm{L}$ (fig. 25, blue symbols). These wells are located within or in proximity to limestone of the Piney Point Formation. By contrast, the largest iron concentrations ranging from $2.4 \mathrm{mg} / \mathrm{L}$ to $3.0 \mathrm{mg} / \mathrm{L}$ were in samples collected from two wells located beyond the extent of the limestone (white symbols), in northwestern Westmoreland County and in southernmost Gloucester County. These wells are at least partly open to silty sand of the Calvert Formation, Newport News unit and basal Plum Point Member, based on comparison of compiled sample-interval altitudes to top-surface altitude contour maps of geologic units and aquifers (see section "Hydrogeologic Framework") (McFarland and Bruce, 2006).

Another 16 water samples from 8 widely spaced wells had iron concentrations from greater than $0.3 \mathrm{mg} / \mathrm{L}$ to $1.0 \mathrm{mg} / \mathrm{L}$ (fig. 25, yellow symbols), and one sample from one well sited near the town of West Point had a concentration of $1.3 \mathrm{mg} / \mathrm{L}$ (fig. 25 , red symbol). On the basis of compiled sample-interval altitudes, 4 of the 8 wells are probably partly open to the silty sand of the Calvert Formation, Newport News unit and basal Plum Point Member. The other 4 wells appear to be open entirely to the limestone of the Piney Point Formation, but only the well near West Point is recorded as having been grouted to the top of the screen. Construction information for the other wells is insufficient to determine whether any sample water may have partly originated from other geologic units, such as through well gravel packs that are longer than their screened intervals. Alternatively, withdrawals from wells open only to the limestone can potentially induce vertical leakage and mixing with water from the overlying silty sand (see sections "Cyclic Pumping" and "Aquifer-Component Test").

In summary, concentrations of iron are generally low throughout most of the Piney Point aquifer; most exceptions are likely attributable to water in the silty sand of the Calvert Formation, Newport News unit and basal Plum Point Member. Dissolved iron along with hydrogen sulfide probably originate primarily from dissolution of pyrite, which is a widespread secondary mineral in the silty sand but is also known to be present in the limestone of the Piney Point Formation. Therefore, some elevated iron concentrations originating from within the limestone cannot be entirely ruled out.

\section{Chloride}

Toward the southeastern part of the study area, the concentration of chloride in water in the Piney Point aquifer increases, and chloride becomes the dominant anion. Elevated chloride concentrations result from mixing of freshwater to the west with saltwater contained in the aquifer to the east.

Chloride-concentration contours for the Piney Point aquifer were mapped from a detailed delineation of the saltwatertransition zone in the eastern part of the Virginia Coastal Plain (McFarland, 2010). Chloride in water in the part of the aquifer southeast of the $250-\mathrm{mg} / \mathrm{L}$ chloride-concentration contour (fig. 25) exceeds the secondary maximum contaminant level (SMCL) of $250 \mathrm{mg} / \mathrm{L}$ (U.S. Environmental Protection Agency, 1990). Likewise, the salinity of water in the part of the aquifer southeast of the $1,000-\mathrm{mg} / \mathrm{L}$ chloride-concentration contour is in the brackish range, and the water requires treatment to be suitable for most uses. Hydrochemical data include chloride concentrations in the Piney Point aquifer as great as $7,120 \mathrm{mg} / \mathrm{L}$ (McFarland, 2010). Beyond the study area to the east, the chloride concentration in the Piney Point aquifer can potentially reach that of seawater, $19,000 \mathrm{mg} / \mathrm{L}$.

Freshwater occupying the landward parts of coastal aquifers is typically separated from saltwater occupying the seaward parts. A landward sloping, diffusive density boundary is aligned parallel to the coast where mixing of freshwater and saltwater takes place in the aquifers. In the Virginia Coastal Plain, however, the saltwater-transition zone three-dimensionally exhibits a broad dome-shaped configuration centered on the Chesapeake Bay impact crater. The saltwater-transition zone thereby protrudes approximately $30 \mathrm{mi}$ landward from a normal coast-parallel alignment (McFarland, 2010). Chlorideconcentration contours for the Piney Point aquifer (fig. 25) are similar to those for other aquifers that align closely with the margin of the impact crater. Most of the saltwater probably originated as seawater but is theorized to have remained immobilized for multiple millions of years within low-permeability sediments that fill the impact crater.

Groundwater withdrawals can potentially cause movement of saltwater from the transition zone toward pumped wells. Withdrawals from the Piney Point aquifer have lowered water levels below sea level (see section "Groundwater Levels") and consequently have produced a landward hydraulic gradient that creates the potential for lateral saltwater intrusion. Although withdrawals in the Virginia Coastal Plain have increased continuously, the position of the saltwater-transition zone is known to be laterally stationary across regionally appreciable distances since it was first mapped more than 100 years ago (Sanford, 1913). In addition, the age of freshwater currently in the Piney Point aquifer has been estimated to be 20,000 years to 37,000 years (Nelms and others, 2003). Thus, withdrawn water has not been displaced across regional distances, and region-wide lateral movement of saltwater could possibly take centuries.

Despite the lack of lateral movement of groundwater, changes in groundwater chloride concentration have been 

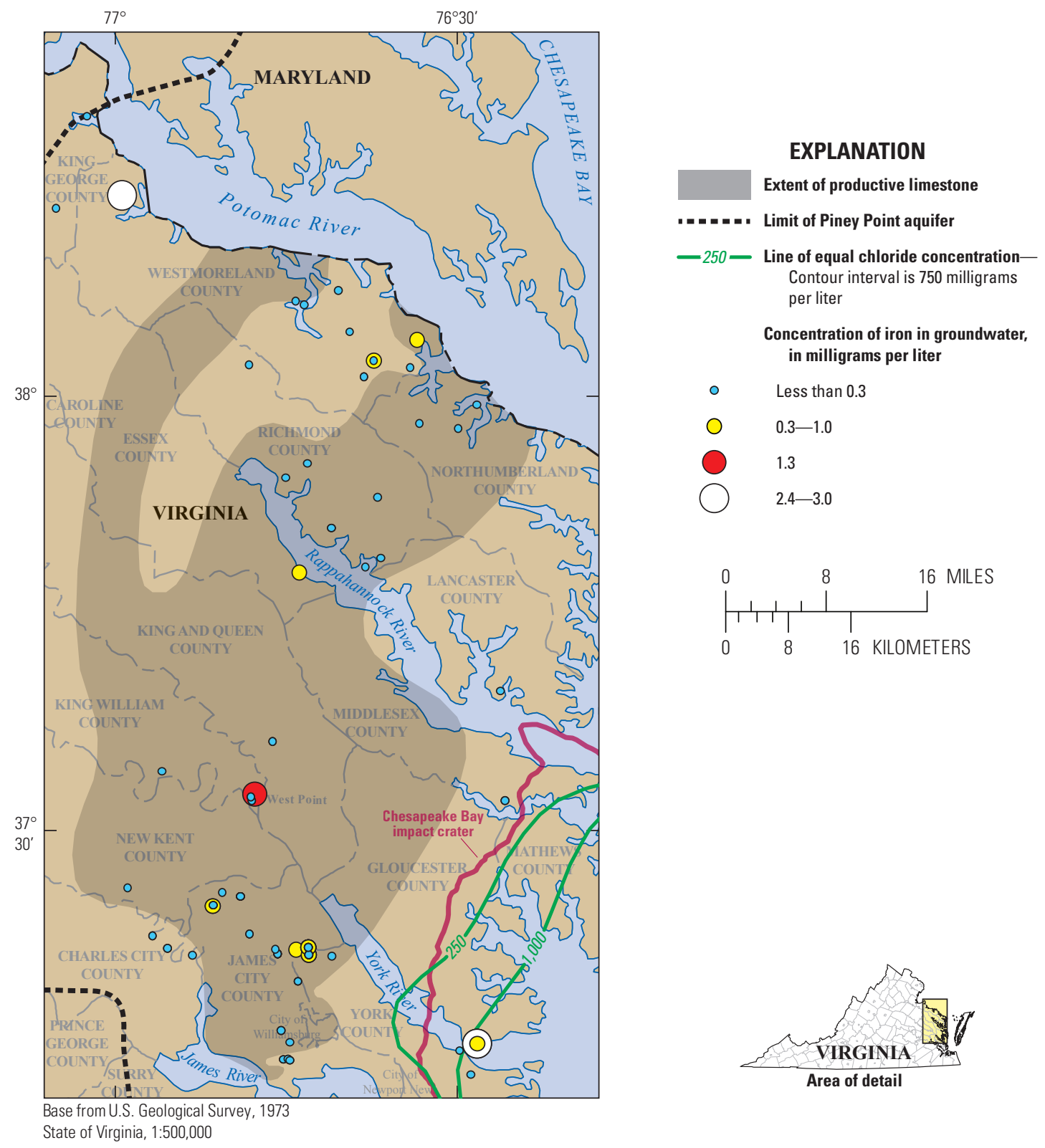

Figure 25. Distribution of iron and chloride in water in the Piney Point aquifer, Virginia.

observed in individual wells. Yearly rates of change in wells in some aquifers have been greater than $1,000 \mathrm{mg} / \mathrm{L}(\mathrm{McFar}-$ land, 2010) and have led to exceedances of the $250-\mathrm{mg} / \mathrm{L}$ SMCL. These changes have been attributed to localized upconing of the saltwater-transition zone directly beneath pumped wells. A vertical density adjustment takes place when a pumping-induced decline in freshwater head causes underlying saltwater to rise. Chloride concentrations in the Piney Point aquifer, however, have been relatively stable compared to those of other aquifers. Yearly rates of change were less than $20 \mathrm{mg} / \mathrm{L}$ in 21 of 23 wells in the Piney Point aquifer, which led to no exceedances of the 250-mg/L SMCL (McFarland, 2010). Although parts of the Piney Point aquifer contain saltwater, the area surrounding the productive limestone, from which withdrawals are made from the aquifer, is apparently located far enough inland to have so far precluded substantial increases in chloride concentration resulting from upconing as of 2015 . 


\section{Resource-Management Considerations}

Information on the Piney Point aquifer presented here can be used to support water-resource management efforts in the Virginia Coastal Plain. Applications of data and interpretive findings can aid in the characterization of the aquifer and provide a context for regulation of groundwater withdrawals.

\section{Aquifer Characterization}

Water-supply planning and development can be aided by information on the diverse lithologies and other aspects of the six geologic units that compose the Piney Point aquifer. Recognition of the individual geologic units could be critical for the success of well-field-scale water-supply development projects in the Piney Point aquifer. Sediment descriptions (see section "Geologic Units"), borehole-interval data (Appendix 1; McFarland, 2017), structural-contour maps (figs. 6-8 and 10-13), and hydrogeologic sections (plate 2) can be used in the design and siting of production wells. Specifically, construction of high yielding wells can be facilitated by sitespecific estimation of geologic-unit depths and thicknesses, and targeting of the productive solution-channeled limestone that composes the Piney Point Formation.

More broadly, the potential for groundwater development among planning areas can be assessed on the basis of the mapped extent of continuous limestone (fig. 8; plate 1) and on apparent trends in aquifer transmissivity (see section "Hydraulic Properties"). Using this information, developmentproject designs can identify optimal production-well locations, estimate completion depths to optimize drilling operations and associated costs, and predict likely yields.

In addition to specific information that supports watersupply planning and development, a broadened perspective on the Piney Point aquifer provides accurate conceptualization of its hydrologic function that is fundamental to its effective management as a water resource. Patterns of water-level response to past withdrawals (see section "Water Levels") can probably be anticipated from future withdrawals. Relations between lateral groundwater flow within geologic units and vertical leakage between them (see section "Conceptual 2-Layer Aquifer Model") can provide the basis for more detailed analysis of flow. Specifically regarding groundwater modeling, the Piney Point aquifer could be vertically discretized with greater resolution to represent the individual geologic units. Of particular interest in this regard is the northeastern part of the Piney Point aquifer that includes relatively thick and fine-grained Gosport equivalent sediments, which likely add a substantially low-permeability interval to the aquifer (plate 2, sections A-A' and B-B'). In addition to better representing the entire Virginia Coastal Plain aquifer system, incorporating this enhanced detail could be particularly important to analyses of smaller parts of the Piney Point aquifer at the sub-regional to county scale.

\section{Regulatory Implications}

Although the geologic units that compose the Piney Point aquifer have been designated collectively as a single aquifer, groundwater withdrawals are made primarily from the productive solution-channeled limestone and interbedded sand that compose the Piney Point Formation. Thus, the VADEQ has considered whether the limestone and sand should be singly regarded as the water-supply resource and regulated as an aquifer apart from the other geologic units from which withdrawals are generally not made.

The VA DEQ currently (2017) limits water-level drawdowns resulting from individual withdrawals to no more than 80 percent of the vertical distance from the pre-development water level to the top surface of the aquifer from which the withdrawals are made. As the Piney Point aquifer is currently designated, the drawdown limit is relative to the top surface of silty sand of the Calvert Formation, Newport News unit and basal Plum Point Member. Limestone and interbedded sand of the Piney Point Formation are positioned at a lower altitude, which if regarded singly as the regulated aquifer, would allow a greater amount of drawdown than was allowed in 2017 and previously.

Some factors could complicate a decision by the VADEQ to regard the limestone and interbedded sand singly as the regulated aquifer. Some production wells have screened intervals that intercept not only the limestone and sand but also other geologic units, most commonly the overlying silty sand of the Calvert Formation, Newport News unit and basal Plum Point Member. In addition, the VA DEQ regards the well gravel pack to represent the entire open interval of the well, which typically extends above and below the well screen and can intercept geologic units other than the limestone and sand.

In addition to well construction, groundwater-flow interactions between the geologic units pertain to how the VA DEQ could regard the Piney Point aquifer in a regulatory context. Pumping induces lateral flow mostly in the limestone and sand of the Piney Point Formation, but pumping also lowers water levels and induces downward leakage in overlying silty sand of the Calvert Formation, Newport News unit and basal Plum Point Member (see section “Aquifer-Component Test"). Pumping among numerous production wells may also create the potential for a zone of mixing of water of contrasting chemical quality between the two geologic units (see section "Iron").

In summary, multiple geologic units that compose the Piney Point aquifer as currently (2017) designated can potentially be intercepted by production wells and can undergo water-level decline and vertical leakage caused by pumping in the limestone and interbedded sand of the Piney Point Formation. Thus, for the VA DEQ to regard the regulated aquifer singly as the limestone and sand creates the additional consideration of whether the other geologic units are to be regarded as regulated aquifers. 


\section{Summary and Conclusions}

A study of the Piney Point aquifer in Virginia was conducted by the U.S. Geological Survey in cooperation with the Virginia Department of Environmental Quality to provide information needed to effectively plan for a sustainable water supply. The Piney Point aquifer is one of several confined aquifers that occupy much of the Virginia Coastal Plain. The Piney Point aquifer is a composite of six separate geologic units with different lateral extents. The study was geographically constrained to the area surrounding one of the geologic units, a solution-channeled limestone from which most of the water from the Piney Point aquifer is produced, and within which the aquifer is entirely confined.

A hydrogeologic framework describes the extents, compositions, configurations, and geologic relations of the six geologic units that compose the Piney Point aquifer and the fine-grained sediments of confining units that immediately overlie and underlie the aquifer. Drillers', geologists', and geophysical logs of 366 boreholes located within, and in proximity to, the productive limestone part of the Piney Point aquifer were interpreted. Hydrogeologic sections represent stratigraphic correlation of the geologic units, and structuralcontour maps represent the altitudes and configurations of their top surfaces.

Geologic units that compose the Piney Point aquifer are in stratigraphically ascending order, the

- sand of the Nanjemoy Formation Woodstock Member,

- interbedded limestone and sand of the Piney Point Formation,

- silty and clayey sand of the Gosport Formation equivalent sediments,

- silty sand of the Oligocene-age sediments,

- silty fine-grained sand of the Old Church Formation, and

- silty sand of the Calvert Formation, Newport News unit and basal Plum Point Member.

The geologic units are underlain by silty and clayey sand of the Nanjemoy Formation Potapaco Member and overlain by silty clayey sand of the Calvert Formation fine-grained Plum Point Member, which form parts of confining units above and below the Piney Point aquifer. The geologic units are designated in a hydrologic context and named on the basis of sediment lithologies that are typical of corresponding geologic formations. Because of differing stratigraphic contacts, however, the geologic units are not everywhere identical to formally recognized geologic formations.

Water-supply wells in the Piney Point aquifer yield as much as 400 gallons per minute from highly porous and solution-channeled indurated limestone within the Piney Point Formation. The limestone is relatively continuous laterally across northwestern Northumberland County and southeastern
Richmond and Essex Counties; and southward across King and Queen County, Middlesex County, eastern King William and New Kent Counties, and western Gloucester County. The limestone extends farthest south in James City County, northernmost York County, and the City of Williamsburg. Lateral continuity is less certain across other parts of Westmoreland, Richmond, Essex, and King and Queen Counties.

All geologic units that compose the Piney Point aquifer dip to the east. Only the Calvert Formation, Newport News unit and basal Plum Point Member spans the entire study area. Underlying geologic units in proximity to the Chesapeake Bay impact crater were either excavated during the impact event or have not been preserved. The Nanjemoy Formation Woodstock Member, Piney Point Formation, and Old Church Formation also pinch out to the northwest and southwest. Gosport Formation equivalent sediments and Oligocene-age sediments are of limited extent to the northeast and pinch out to the west.

The configurations of most of the geologic units that compose the Piney Point aquifer are further affected by an array of faults aligned radially from the Chesapeake Bay impact crater. A complex series of horsts and grabens possibly reflects an outer disruption zone that makes up part of a broad regional impact structure. The faults appear further related to some geomorphic features and to have influenced present-day topography and drainage. Faults also create irregularities in the lateral continuity of the geologic units. Interbedded limestone and sand of the Piney Point Formation are dislocated vertically along faults to abut adjacent geologic units and create lateral flow constrictions or barriers.

Some of the geologic units that compose the Piney Point aquifer are truncated beneath the lower Rappahannock River by a remnant resurge channel associated with the Chesapeake Bay impact crater. Post-impact resurge of water and excavated sediment across an outer disruption zone outside the crater cavity was focused along the channel into the crater cavity. Geologic units originally present outside the crater cavity were scoured away along the channel but remain preserved at short distances outside the channel.

Annual rates of groundwater withdrawal in the Virginia Coastal Plain during 1900-2009 were obtained from a published groundwater study of the North Atlantic Coastal Plain. Groundwater withdrawals from the Piney Point aquifer increased from approximately 1 million gallons per day (Mgal/d) during 1900 for mostly unregulated domestic use to $7.35 \mathrm{Mgal} / \mathrm{d}$ during 2004 for mostly regulated uses. Withdrawals then decreased to $5.01 \mathrm{Mgal} / \mathrm{d}$ by 2009 as a result of a reduction in regulated uses. Large withdrawals that are geographically concentrated on the York-James Peninsula and supply public drinking water became fewer between 2004 and 2009 , and withdrawals decreased from 3.09 Mgal $/ \mathrm{d}$ to $1.16 \mathrm{Mgal} / \mathrm{d}$. Withdrawals were shifted from the Piney Point aquifer to withdrawals and treatment of deeper brackish groundwater from the Potomac aquifer. Withdrawals from the Piney Point aquifer at the town of West Point for mostly industrial use also decreased during 2004-09 from $1.77 \mathrm{Mgal} / \mathrm{d}$ to $1.34 \mathrm{Mgal} / \mathrm{d}$. By contrast, withdrawals on the Northern Neck 
and Middle Peninsula became more numerous and increased from $0.11 \mathrm{Mgal} / \mathrm{d}$ to $0.13 \mathrm{Mgal} / \mathrm{d}$, mostly for expanding community drinking-water systems. This geographic shift indicates that withdrawals from the Piney Point aquifer are gradually broadening.

Water levels in the Piney Point aquifer from discrete measurements made during 1906-2015 in 19 observation wells, continuous measurements during 2008-09 in 10 production wells, and continuous measurements during March-September 2015 in 4 wells were evaluated. Yearly mean water levels in observation wells in James City County during 1960-95 declined from close to or above sea level to as deep as nearly -60 feet (ft). Water levels in one of the observation wells continued to decline until 2005 , then partially recovered by approximately $14 \mathrm{ft}$ by 2015 . Water levels in other observation wells located outside James City County remained close to or above sea level.

A water-level cone of depression in the Piney Point aquifer in James City and northern York Counties was indicated by approximately seasonal static water levels in production wells during 2008-09. Fluctuation in the cone of depression resulted from a seasonal demand imposed on the public drinking-water system. At the center of the cone of depression, the seasonal static water level of $-63 \mathrm{ft}$ during September 2008 recovered to $-53 \mathrm{ft}$ by May 2009 , and then declined to $-59 \mathrm{ft}$ by August 2009. Water levels on the higher flanks of the cone of depression to the northwest and southeast were relatively stable within 1 or $2 \mathrm{ft}$.

On the basis of relations among water levels in observation wells and production wells, the center of the cone of depression in 2003-05 was possibly as low as $-70 \mathrm{ft}$ but probably recovered by 2015 to approximately $-50 \mathrm{ft}$. Water levels recovered as withdrawals shifted away from the Piney Point aquifer. Continued seasonal fluctuation in the cone of depression during 2015 was indicated by water-level recovery in observation wells from early March to May, followed by decline through September. Also during decline, local rainfall events recharged the water table in the surficial aquifer, thereby increasing hydrostatic pressure and producing partial water-level recoveries in the underlying Piney Point aquifer.

Multi-hour water-level fluctuations of several tenths of a foot in observation wells open to the Piney Point aquifer in northern York County coincided with cyclical pumping of nearby production wells during 2015 . The vertical hydraulic gradient between the limestone of the Piney Point Formation and overlying silty sand of the Calvert Formation, Newport News unit and basal Plum Point Member regularly reversed direction from downward during pumping to upward during recovery. Alternating periods of pumping among numerous production wells in the Piney Point aquifer in James City and northern York Counties widely create the potential for a zone of vertical leakage and mixing between the two geologic units.

Hydraulic properties of the Piney Point aquifer were estimated from 14 aquifer tests conducted during 1972-2011 in Virginia and an adjacent part of Maryland. Estimated transmissivities in York and James City Counties range from
840 feet squared per day $\left(\mathrm{ft}^{2} / \mathrm{d}\right)$ to $30,907 \mathrm{ft}^{2} / \mathrm{d}$ with a mean of $16,300 \mathrm{ft}^{2} / \mathrm{d}$. Smaller estimates of transmissivity farther north range from $260 \mathrm{ft}^{2} / \mathrm{d}$ to $1,900 \mathrm{ft}^{2} / \mathrm{d}$ with a mean of $925 \mathrm{ft}^{2} / \mathrm{d}$. Estimates of storativity from three aquifer tests range from $8.90 \times 10^{-6}$ to $1.98 \times 10^{-5}$. For comparison, specific capacities were compiled of 53 wells in Virginia and 123 wells in Maryland. Well specific capacities in York and James City Counties range from 0.19 gallons per minute per foot (gal $/ \mathrm{min} / \mathrm{ft}$ ) to $72.5 \mathrm{gal} / \mathrm{min} / \mathrm{ft}$, with a mean of $11.4 \mathrm{gal} / \mathrm{min} / \mathrm{ft}$. Smaller specific capacities farther north in Virginia range from $0.12 \mathrm{gal} / \mathrm{min} / \mathrm{ft}$ to $7.57 \mathrm{gal} / \mathrm{min} / \mathrm{ft}$ with a mean of $2.26 \mathrm{gal} / \mathrm{min} / \mathrm{ft}$. The smallest specific capacities are for wells in Maryland, ranging from $0.2 \mathrm{gal} / \mathrm{min} / \mathrm{ft}$ to $4 \mathrm{gal} / \mathrm{min} / \mathrm{ft}$, with a mean of $0.99 \mathrm{gal} / \mathrm{min} / \mathrm{ft}$. The northward decrease in specific capacity is probably unrelated to well efficiency but rather reflects the northward decrease in transmissivity resulting from poor development of the solution-channeled limestone.

Another aquifer test conducted in northern York County during March 17-19, 2015, was used to determine hydraulic properties of, and flow interaction between, geologic units that compose the Piney Point aquifer. Water-level depths below land surface measured prior to and during the aquifer test were used to estimate antecedent water-level depths and calculate water-level drawdowns and recoveries. Pumping of limestone and interbedded sand of the Piney Point Formation induced time-lagged water-level decline and vertical leakage in the overlying silty sand of the Calvert Formation, Newport News unit and basal Plum Point Member. Early decreases in slope of water-level drawdown and recovery log-linear trends with respect to time probably represent a change in the response of the Piney Point aquifer from a single layer to two layers. On this basis, transmissivity of the limestone and sand was estimated to be $19,800 \mathrm{ft}^{2} / \mathrm{d}$ to $19,900 \mathrm{ft}^{2} / \mathrm{d}$, and of the overlying silty sand to be $2,400 \mathrm{ft}^{2} / \mathrm{d}$ to $2,600 \mathrm{ft}^{2} / \mathrm{d}$. Horizontal hydraulic conductivity of the limestone and sand was calculated to be 0.91 feet per minute ( $\mathrm{ft} / \mathrm{min}$ ) to $0.92 \mathrm{ft} / \mathrm{min}$, and of the silty sand to be $0.06 \mathrm{ft} / \mathrm{min}$ to $0.07 \mathrm{ft} / \mathrm{min}$. Later increases in drawdown and recovery trend slopes are probably the result of interception of a fault-associated no-flow boundary.

Published hydrochemical data indicate that most of the water in the Piney Point aquifer is slightly alkaline, contains moderate concentrations of dissolved solids dominated by sodium cations and bicarbonate anions, and is from 20,000 years old to 37,000 years old. The water is generally slightly undersaturated with respect to calcite. Calcite dissolution coupled with cation exchange by glauconite and clay minerals has produced well developed solution channeling in the limestone of the Piney Point Formation, to which the productivity of the Piney Point aquifer is largely attributed. The concentration of iron in water in the Piney Point aquifer is generally below the secondary drinking-water standard of 0.3 milligrams per liter $(\mathrm{mg} / \mathrm{L})$. Larger iron concentrations of as much as $3.0 \mathrm{mg} / \mathrm{L}$ are largely attributable to dissolution of pyrite by water in silty sand of the Calvert Formation, Newport News unit and basal Plum Point Member. Chloride concentrations to the southeast are as great as $7,120 \mathrm{mg} / \mathrm{L}$ and result from mixing of freshwa- 
ter with seawater from low-permeability sediments that fill the Chesapeake Bay impact crater. Changes in chloride concentration in wells result primarily from localized upconing of saltwater rather than region-wide lateral movement. Chloride concentrations have been more stable in the Piney Point aquifer than in some other aquifers, possibly because withdrawals from the aquifer are generally made relatively far inland.

The Piney Point aquifer was characterized to address information needs for water-resource management in the Virginia Coastal Plain. Recognition of individual geologic units that compose the Piney Point aquifer can be critical for successful design and siting of production wells in the productive solution-channeled limestone. The potential for groundwater development among planning areas also can be assessed to optimize production-well locations and drilling operations, and to predict likely yields. Accurate conceptualization of the hydrologic function of the Piney Point aquifer is provided by patterns of water-level response to withdrawals and by relations between lateral groundwater flow and vertical leakage among the geologic units. Flow can potentially be evaluated in greater detail by models that vertically discretize individual geologic units.

For the VA DEQ to singly regard the limestone and interbedded sand of the Piney Point Formation as a regulated aquifer, a greater amount of drawdown would be allowed than currently (2017) with the Piney Point aquifer considered to consist of six geologic units. Some production wells, however, intercept multiple geologic units. In addition, although pumping induces lateral flow mostly in the limestone and sand, water levels are lowered and vertical leakage is induced in other geologic units. Water of contrasting chemical quality can also mix from multiple geologic units. Whether the other geologic units are to be regarded as regulated aquifers is an additional consideration for the VA DEQ.

\section{References Cited}

Andreasen, D.C., Achmad, Grufron, and Staley, A.W., 2013, Maryland Coastal Plain aquifer information system: Hydrogeologic framework: Maryland Geological Survey OpenFile Report 12-02-20, 121 p., http://www.mgs.md.gov/ publications/report_pages/OFR_12-02-20.html.

Ball, J.W., and Nordstrom, D.K., 1991, User's manual for WATEQ4F, with revised thermodynamic data base and text cases for calculating speciation of major, trace, and redox elements in natural waters: U.S. Geological Survey OpenFile Report 91-183, 193 p.

Baum, G.R., 1980, Petrography and depositional environments of the middle Eocene Castle Hayne limestone, North Carolina: Southeastern Geology, v. 21, no. 3, p. 175-196.
Cederstrom, D.J., 1939, Geology and artesian-water resources of a part of the southern Virginia Coastal Plain: Virginia Geological Survey Bulletin 51-E, p. 123-136.

Cederstrom, D.J., 1945, Geology and ground-water resources of the Coastal Plain in southeastern Virginia: Virginia Geological Survey Bulletin 63, 384 p.

Cederstrom, D.J., 1946, Chemical character of ground water in the Coastal Plain of Virginia: Virginia Geological Survey Bulletin 68, $62 \mathrm{p}$.

Cederstrom, D.J., 1968, Geology and ground-water resources of the Middle Peninsula, Virginia: U.S. Geological Survey Open-File Report (unnumbered), 231 p.

Cooper, H.H. and Jacob, C.E., 1946, A generalized graphical method for evaluating formation constants and summarizing well field history: American Geophysical Union Transactions, v.27, p. 526-534.

Darton, N.H., 1896, Artesian well prospects in the Atlantic Coastal Plain region: U.S. Geological Survey Bulletin 138, 232 p.

Dickson, J.A.D., 1965, A modified staining technique for carbonates in thin section: Nature, v. 540, p. 587.

Drummond, D.D., 1984, Records of selected wells, Calvert and St. Mary's Counties, Maryland: Maryland Geological Survey Basic Data Report 14, 117 p.

Ellison, R.P., III, and Masiello, R.A., 1979, Groundwater resources of Hanover County, Virginia: Virginia State Water Control Board Planning Bulletin 314, 130 p.

Eggleston, Jack, and Pope, Jason, 2013, Land subsidence and relative sea-level rise in the southern Chesapeake Bay region: U.S. Geological Survey Circular 1392, 30 p., http:// dx.doi.org/10.3133/cir1392.

Foster, M.D., 1950, The origin of high sodium bicarbonate waters in the Atlantic and Gulf Coastal Plains: Geochimica et Cosmochimica Acta, v. 1, no. 1, p. 33-48.

Freeze, R.A., and Cherry, J.A., 1979, Groundwater: Englewood Cliffs, N.J., Prentice Hall, 604 p.

Geraghty and Miller, Consulting Ground-Water Geologists, 1967, The status of ground-water resources, 1967, Nansemond County and Isle of Wight County, Virginia: Port Washington, New York, Geraghty and Miller, Consulting Ground-Water Geologists, 44 p.

Hamilton, P.A., and Larson, J.D., 1988, Hydrogeology and analysis of the ground-water flow system in the Coastal Plain of southeastern Virginia: U.S. Geological Survey Water-Resources Investigations Report 87-4240, 175 p. 
Harsh, J.F., and Laczniak, R.J., 1990, Conceptualization and analysis of ground-water flow system in the Coastal Plain of Virginia and adjacent parts of Maryland and North Carolina: U.S. Geological Survey Professional Paper 1404-F, 100 p.

Heywood, C.E., and Pope, J.P., 2009, Simulation of groundwater flow in the Coastal Plain aquifer system of Virginia: U.S. Geological Survey Scientific Investigations Report 2009-5039, $115 \mathrm{p}$.

Javendel, Iraj, and Witherspoon, P.A., 1983, Analytical solution of a partially penetrating well in a two-layer aquifer: Water Resources Research, v. 19, no. 2, p. 567-578.

Kruseman, G.P., and de Ridder, N.A., 2000, Analysis and evaluation of pumping test data: Wageningen, The Netherlands, International Institute for Land Reclamation and Improvement, $377 \mathrm{p}$.

Laczniak, R.J., and Meng, A.A., III, 1988, Ground-water resources of the York-James Peninsula of Virginia: U.S. Geological Survey Water-Resources Investigations Report 88-4059, 178 p.

Masterson, J.P., Pope, J.P., Fienen, M.N., Monti, Jack, Jr., Nardi, M.R., and Finkelstein, J.S., 2016, Documentation of a groundwater flow model developed to assess groundwater availability in the Northern Atlantic Coastal Plain aquifer system from Long Island, New York, to North Carolina: U.S. Geological Survey Scientific Investigations Report 2016-5076, 70 p., http://dx.doi.org/10.3133/sir20165076.

McFarland, E.R., 1999, Hydrogeologic framework and ground-water flow in the Fall Zone of Virginia: U.S. Geological Survey Water-Resources Investigations Report 99-4093, 83 p.

McFarland, E.R., 2010, Groundwater-quality data and regional trends in the Virginia Coastal Plain, 1906-2007: U.S. Geological Survey Professional Paper 1772, 86 p.

McFarland, E.R., 2013, Sediment distribution and hydrologic conditions of the Potomac aquifer in Virginia and parts of Maryland and North Carolina: U.S. Geological Survey Scientific Investigations Report 2013-5116, 67 p.

McFarland, E.R., 2015, A conceptual framework and monitoring strategy for movement of saltwater in the Coastal Plain aquifer system of Virginia: U.S. Geological Survey Scientific Investigations Report 2015-5117, 30 p.

McFarland, E.R., 2017, Borehole geologic-unit top-surface altitude and aquifer-component test data for the Piney Point aquifer, Virginia from 2009 through 2015: U.S. Geological Survey data release, https://doi.org/10.5066/F7BV7DV5.

McFarland, E.R., and Bruce, T.S., 2006, The Virginia Coastal Plain hydrogeologic framework: U.S. Geological Survey Professional Paper 1731, 118 p., 25 pls.
Meng, A.A., III, and Harsh, J.F., 1988, Hydrogeologic framework of the Virginia Coastal Plain: U.S. Geological Survey Professional Paper 1404-C, 82 p.

Mixon, R.B., Berquist, C.R., Jr., Newell, W.L., Johnson, G.H., Powars, D.S., Schindler, J.S., and Rader, E.K., 1989, Geologic map and generalized cross sections of the Coastal Plain and adjacent parts of the Piedmont, Virginia: U.S. Geological Survey Miscellaneous Investigations Series Map I-2033, scale 1:250,000.

Munsell Color, 1998, Munsell soil color charts: New Windsor, N.Y., GretagMacbeth, 10 p.

Nelms, D.L., Harlow, G.E., Plummer, L.N., and Busenberg, Eurybiades, 2003, Aquifer susceptibility in Virginia, 19982000: U.S. Geological Survey Water-Resources Investigations Report 03-4278, $58 \mathrm{p}$.

Newton, V.P., and Siudyla, E.A., 1979, Groundwater of the Northern Neck Peninsula, Virginia: Virginia State Water Control Board Planning Bulletin 307, 48 p.

Poag, C.W., Koeberl, Christian, and Reimold, W.U., 2004, The Chesapeake Bay Crater: Springer, New York, 522 p. and CD-ROM.

Pope, J.P., McFarland, E.R., and Banks, R.B., 2008, Private domestic-well characteristics and the distribution of domestic withdrawals among aquifers in the Virginia Coastal Plain: U.S. Geological Survey Scientific Investigations Report 2007-5250, 47 p.

Powars, D.S., 2000, The effects of the Chesapeake Bay impact crater on the geological framework and correlation of hydrogeologic units of southeastern Virginia, south of the James River: U.S. Geological Survey Professional Paper 1622, 53 p., 1 pl.

Powars, D.S., and Bruce, T.S., 1999, The effects of the Chesapeake Bay impact crater on the geological framework and correlation of hydrogeologic units of the lower York-James Peninsula, Virginia: U.S. Geological Survey Professional Paper 1612, 82 p., 9 pls.

Russnow-Kane and Associates, 1996a, Report on the hydrogeologic framework and well construction activities at the Canterbury production well site, Chickahominy-Piney Point aquifer well lot W-22: Newport News, Va., Russnow-Kane and Associates, $15 \mathrm{p}$.

Russnow-Kane and Associates, 1996b, Report on the hydrogeologic framework and well construction activities at the Kristiansand production well site, Chickahominy-Piney Point aquifer well lot W-38: Newport News, Va., RussnowKane and Associates, $15 \mathrm{p}$. 
Russnow-Kane and Associates, 1996c, Report on the hydrogeologic framework and well construction activities at the Norge production well site, Chickahominy-Piney Point aquifer well lot W-24: Newport News, Va., Russnow-Kane and Associates, $15 \mathrm{p}$.

Russnow-Kane and Associates, 2010, Report on the hydrogeologic framework and well construction activities at the Summerplace production well site, Chickahominy-Piney Point aquifer well lot W-44-1: Newport News, Va., RussnowKane and Associates, $13 \mathrm{p}$.

Sanford, Samuel, 1913, The underground water resources of the Coastal Plain Province of Virginia: Virginia Geological Survey Bulletin 5, $361 \mathrm{p}$.

Siudyla, E.A., Berglund, T.D., and Newton, V.P., 1977, Ground water of the Middle Peninsula, Virginia: Virginia State Water Control Board Planning Bulletin 305, 90 p.

Siudyla, E.A., May, A.E., and Hawthorn, D.W., 1981, Ground water resources of the four cities area, Virginia: Virginia State Water Control Board Planning Bulletin 331, 90 p.

U.S. Environmental Protection Agency, 1990, Secondary maximum-contaminant levels (section 143.3 of part 143, National secondary drinking water regulations): U.S. Code of Federal Regulations, Title 40, Parts 100 to 149, revised as of July 1, 1990, p. 674.

Virginia State Water Control Board, 1973, Ground water of the York-James Peninsula, Virginia: Virginia State Water Control Board, Bureau of Water Control Management, Basic Data Bulletin 39, 74 p.

Vroblesky, D.A., and Fleck, W.B., 1991, Hydrogeologic framework of the Coastal Plain of Maryland, Delaware, and the District of Columbia: U.S. Geological Survey Professional Paper 1404-E, 45 p., 2 pls.

Wigglesworth, H.A., Perry, T.W., and Ellison, R.P., III, 1984, Groundwater resources of Henrico County, Virginia: Virginia State Water Control Board Planning Bulletin 328, $118 \mathrm{p}$.

Winner, M.D., Jr., and Coble, R.W., 1996, Hydrogeologic framework of the North Carolina Coastal Plain: U.S. Geological Survey Professional Paper 1404-I, 106 p., 24 pls. 


\section{Appendix 1. Borehole Geologic-Unit Top-Surface Altitudes, Piney Point Aquifer, Virginia}

Available on CD-ROM in pocket or online at https://doi.org/10.3133/sir20175041.

\section{Appendix 2 Aquifer-Component Test Data, Piney Point Aquifer, Virginia}

Available on CD-ROM in pocket or online at https://doi.org/10.3133/sir20175041. 

Publishing support provided by the U.S. Geological Survey Science Publishing Network, West Trenton Publishing Service Center

For more information concerning the research in this report, contact: Virginia Water Science Center

U.S. Geological Survey

1730 East Parham Road

Richmond, Virginia 23228

http://va.water.usgs.gov/ 
